UNIVERSIDADE DE SÃO PAULO

FACULDADE DE MEDICINA DE RIBEIRÃO PRETO

PROGRAMA DE PÓS-GRADUAÇÃO EM GENÉTICA

ISABELA ICHIHARA DE BARROS

Análise da expressão de RNAs longos não codificantes em tumores metastáticos de câncer de mama

RIBEIRÃO PRETO

2016 
ISABELA ICHIHARA DE BARROS

Análise da expressão de RNAs longos não codificantes em tumores metastáticos de câncer de mama

Dissertação apresentada à Faculdade de Medicina de Ribeirão Preto da Universidade de São Paulo, para obtenção do título de Mestre em Ciências

Área de concentração: Genética

Orientador: Prof. Dr. Wilson Araújo da Silva Junior

Ribeirão Preto 
Autorizo a reprodução e divulgação total ou parcial deste trabalho, por qualquer meio convencional ou eletrônico, para fins de estudo e pesquisa, desde que citada a fonte.

FICHA CATALOGRÁFICA

Ichihara de Barros, Isabela

Análise da expressão de RNAs longos não codificantes em tumores metastáticos de câncer de mama. / Isabela Ichihara de Barros; Orientador. Wilson Araujo da Silva Junior. - Ribeirão Preto, 2016.

92f.:il; $30 \mathrm{~cm}$

Dissertação de Mestrado apresentada à Faculdade de Medicina de Ribeirão Preto/USP. Área de concentração: Genética; Orientador: Araujo da Silva Junior, Wilson

1. IncRNAs. 2. Câncer de mama. 3. Metástase 
NOME: BARROS, Isabela Ichihara de

TÍTULO: Análise da expressão de RNAs longos não codificantes em tumores metastáticos de câncer de mama

Dissertação apresentada à Faculdade de Medicina de Ribeirão Preto da Universidade de São Paulo, para obtenção do título de Mestre em Ciências

Aprovada em:

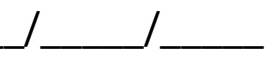

Banca examinadora

$\operatorname{Dr}(a)$ : Instituição

Julgamento: Assinatura:

$\operatorname{Dr}(\mathrm{a})$ : Instituição

Julgamento: Assinatura:

$\operatorname{Dr}(a)$ : Instituição

Julgamento: Assinatura: 


\section{APOIO E SUPORTE FINANCIERO}

Este trabalho bem como a sua apresentação em diversos congressos foi realizado com o apoio financeiro das seguintes instituições e entidades:

> Fundação de Amparo à Pesquisa do Estado de São Paulo - FAPESP.

> Conselho Nacional de Desenvolvimento Científico e Tecnológico - CNPq.

> Coordenação de Aperfeiçoamento de Pessoal de Nível Superior - CAPES.

$>$ Fundação de Apoio ao Ensino, Pesquisa e Assistência - FAEPA.

$>$ Faculdade de Medicina de Ribeirão Preto - FMRP/USP.

$>$ Fundação Hemocentro de Ribeirão Preto. 


\section{AGRADECIMENTOS}

Agradeço primeiramente à minha mãe, por ser meu porto seguro e minha guia. Ao meu pai, por todo o apoio e por todo o carinho de sempre. Ao meu irmão, pelo companheirismo e por me tornar sempre mais leve.

À minha família, que sempre torceu por mim. Especialmente à minha avó, Maria Eleonora, por toda sua fé e amor, e aos meus tios Ana e Gilson e primos Cauê e Luisa, por todo suporte e ajuda e por serem meus segundos pais e irmãos.

A Dilo, por estar sempre ao meu lado, me apoiando em todas as minhas decisões, e por toda a compreensão, companheirismo e carinho que tem me dedicado.

Ao professor Wilson Araújo da Silva Junior, por ter me recebido de portas abertas e pela orientação durante a realização deste trabalho.

Aos meus companheiros de laboratório, sem os quais o dia-a-dia não teria sido tão agradável e divertido. É muito bom fazer parte da família LGMB.

Aos professores Daniel Tiezzi, Daniela Tirapelli e Gilberto Carlotti pela colaboração.

À professora Vanessa Silveira, ao professor Tiago Pereira e ao professor Rodrigo Panepucci pelas contribuições no exame de qualificação.

Ao Programa de Pós-Graduação em Genética e ao Departamento de Genética da Faculdade de Medicina de Ribeirão Preto. Um agradecimento especial à Susie, por toda a ajuda.

À Fundação Hemocentro da Faculdade de Medicina de Ribeirão Preto, onde este trabalho foi realizado.

À CAPES pela concessão da bolsa de mestrado e apoio financeiro para realização deste trabalho.

À FAPESP, ao CNPq e à FAEPA, pelo apoio financeiro. 
Às meninas da Casina, Ayling e Melina, por todo o suporte, torcida e pelos ótimos momentos que passamos juntas.

Às meninas da Rep Hour, Estela, Mariana e Carla, que me acolheram tão bem em Ribeirão.

Aos amigos que fiz em Ribeirão e àqueles que estavam distantes, por tornarem tudo mais feliz. Agradeço especialmente a Luiza, Thyago, Leandro, Rafael e Laís, amigos de toda uma vida, que, independente da distância, estão comigo aonde eu for; a Maria e a Thiago, queridos conterrâneos que sempre me acompanham; a Pedro, Vívian, Patrícia e Samir, por toda a torcida e a certeza de que sempre teremos uns aos outros; a Eudes, Isabela, Jessica, Ivan, Ayling, Rafaela e José, por todo o carinho e amizade.

A todos que contribuíram de alguma maneira para a realização deste trabalho. 


\section{RESUMO}

\section{BARROS, I. I. Análise da expressão de RNAs longos não codificantes em tumores}

metastáticos de câncer de mama. 2016. 92 f. Dissertação (Mestrado) - Faculdade de Medicina de Ribeirão Preto, Universidade de São Paulo, Ribeirão Preto, 2016.

O câncer de mama é um dos que mais afeta mulheres em todo o mundo e em 2016 estima-se que haverá aproximadamente 58 mil novos casos no Brasil. É uma doença caracteristicamente heterogênea, o que dificulta o diagnóstico, prognóstico e a abordagem terapêutica utilizada. Os biomarcadores já existentes para câncer de mama não são suficientes para explicar a ocorrência de metástase, que é a principal causa de morte entre os pacientes. Neste sentido, os RNAs longos não codificadores (IncRNAs) vêm se estabelecendo como importantes moléculas regulatórias em diversos processos biológicos e alguns têm sido associados com o desenvolvimento e a progressão do câncer de mama. Apesar disso, muito ainda precisa ser elucidado a respeito dessa nova classe de ncRNAs e seu envolvimento na metástase. Desta forma, determinar uma assinatura de IncRNAs em tumores metastáticos de mama pareados com seus respectivos tumores primários pode sugerir novas moléculas envolvidas no mecanismo de metástase. Neste estudo, foram analisadas amostras de cinco tumores primários de mama e seus correspondentes metastáticos em Sistema Nervoso Central $(n=2)$ e em linfonodos $(n=3)$. O RNA total de cada amostra foi extraído e avaliado quanto à sua qualidade para obtenção do transcriptoma pelo método de RNA-Seq. Para o tratamento dos dados foram usados os aplicativos: Tophat para o alinhamento das reads, o Cufflinks para a montagem e quantificação dos transcritos e o pacote DESeq2 para análise de expressão diferencial. O resultado da análise demonstrou que os IncRNAs com íntrons retidos são os mais abundantes e que as amostras de tumores primários e metastáticos compartilham a maioria dos IncRNAs expressos, tornando-os qualitativamente bastante semelhantes entre si. Dentre os IncRNAs diferencialmente expressos, doze são comuns entre os tumores primários, independente dos subtipos moleculares das amostras, e não há transcritos comuns às amostras metastáticas. A análise de agrupamento hierárquico definiu três assinaturas de expressão de IncRNAs para as amostras de tumores primários, metástase em cérebro e em linfonodos, podendo indicar IncRNAs potencialmente envolvidos no mecanismo de metástase.

Palavras-chave: IncRNA, metástase, câncer de mama. 


\section{BARROS, I. I. Analysis of the expression of long noncoding RNAs in breast cancer metastatic}

tumors. 2016. 92 f. Dissertação (Mestrado) - Faculdade de Medicina de Ribeirão Preto, Universidade de São Paulo, Ribeirão Preto, 2016.

Breast cancer is the principall cancer that affects women in the world and it is expect to Brazil, 58.000 new cases in 2016. It is a heterogeneous disease, what makes diagnosis, prognosis and therapeutical approach more difficult. Existing biomarkers for breast cancer are not sufficient to explain metastasis occurrence, which is the main cause of mortality. In this way, long non-coding RNAs (IncRNAs) have been establishing as important regulatory molecules in several biological processes and some of them have been associated to breast cancer development and progression. Nevertheless, many aspects about this new ncRNA class and its involvement in metastasis need to be elucidated. Thus, determining a IncRNA signature of metastatic tumors paired with their related primary tumors may indicate new molecules involved in the mecanism of metastasis. In the present study, Five samples of primary breast tumors and their related metastasis in central nervous system $(n=2)$ and in lymph nodes $(n=3)$ were analyzed. Total RNA of each sample was extracted and had its quality evaluated for transcriptome obtainment by RNA-Seq method. Data processing was performed utilizing the applications: Tophat, for read alignment; Cufflinks, for transcripts assembly and quantification; and DESeq2 package, for differential expression analysis. The results revealed that IncRNAs containing retained introns are the most abundant transcripts and that primary and metastatic samples share most of the expressed IncRNAs, what makes them qualitatively similar to each other. Differential expression analysis showed that twelve IncRNAs are common among primary tumors, apart from samples mollecular subtypes, and metastatic tumors do not have any transcript in common. Hierarchical clustering analysis defined three IncRNA expression signatures, for primary tumors, brain and lymph node metastatis, what may indicate IncRNAs potentially involved in metastasis mechanism.

Key words: IncRNAs, metastasis, breast cancer. 


\section{LISTA DE FIGURAS}

Figura 1 - LncRNAs em relação a genes codificadores de proteínas e suas denominações. E, éxon; UTR, região não

traduzida .31

Figura 2 - Visão geral da progressão do câncer de mama. O esquema retrata uma sessão transversal de um ducto mamário dividido em quadrantes que representam cada estágio da progressão do ducto normal até o IDC. Características epiteliais e potenciais IncRNAs associados com cada fase também são mostrados. .32

Figura 3 - Amostras tumorais primárias e metastáticas obtidas para o presente estudo.......36

Figura 4 - Representação da amplificação em ponte. As fitas de cDNA se hibridizam à camada de oligonucleotídeos presente na superfície da célula de fluxo, curvando-se em formato de ponte. As fitas são copiadas por DNA polimerase, formando pontes dupla fita que são subsequentemente desnaturadas. A repetição dos ciclos de amplificação e desnaturação geram milhares de agrupamentos clonais. .39

Figura 5 - Classes de RNAs às quais pertencem as reads mapeadas resultantes do RNA-seq das amostras tumorais. Tumores primários de mama (A) pareados com metástases em linfonodos (B) e tumores primários de mama (C) pareados com metástases em cérebro (D).

Figura 6 - Classes de IncRNAs encontradas nas amostras tumorais após o mapeamento. Tumores primários de mama (A) e seus correspondentes metastáticos em linfonodo (B); tumores primários de mama (C) e seus correspondentes metastáticos em cérebro (D) 46

Figura 7 - LncRNAs comuns e exclusivos entre os pares de (A) tumores primários de mama e respectivas metástases em linfonodo e (B) tumor primário de mama e respectivas metástases em cérebro 
Figura 8 - LncRNAs comuns e exclusivos entre as amostras de tumor primário de mama (A) e de tumor metastático de mama (B). Cores iguais correspondem a um par tumor primário-tumor metastático

Figura 9 - Expressão de IncRNAs já conhecidos em câncer de mama nas amostras tumorais. À esquerda das colunas de tumores metastáticos ( $M L$ e $M C)$ encontram-se as $\begin{array}{llll}\text { colunas dos } & \text { seus } & \text { tumores }\end{array}$

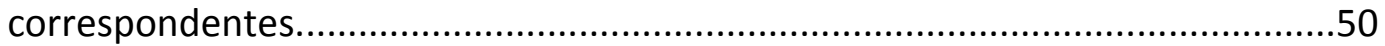

Figura 10 - Expressão diferencial de IncRNAs entre as amostras de tumor de mama primário e seus correspondentes metastáticos. Em azul, IncRNAs mais expressos nas metástases; em vermelho, IncRNAs mais expressos nos tumores primários

Figura 11 - Agrupamento hierárquico dos IncRNAs com expressão diferencial entre as amostras tumorais .54

Figura 12 - PCR semi-quantitativa do IncRNA LINC00472. Assim como os valores de expressão obtidos do RNA-Seq (A), a PCR demonstrou variação na expressão desse transcrito nas amostras tumorais (B). TUBB, endógeno ( $\beta$-tubulina); PM, tumor primário de mama; ML, metástase em linfonodo; $M C$, metástase em cérebro. Em B, números iguais correspondem a um par tumor primáriometástase 


\section{LISTA DE TABELAS}

Tabela 1 - Características histológicas e clínico-patológicas dos tumores de mama...............42

Tabela 2 - Avaliação da integridade dos RNAs extraídos das amostras tumorais.

Tabela 3 - Total de reads geradas pelo RNA-seq das amostras tumorais primárias e metastáticas e quantidade de reads mapeadas contra o genoma de referência GRCh37.p13....... 


\section{LISTA DE ABREVIATURAS E SIGLAS}

\begin{tabular}{|c|c|}
\hline CDIS & Carcinoma ductal in situ \\
\hline cDNA & DNA complementar \\
\hline CLIS & Carcinoma lobular in situ \\
\hline СТC & Célula tumoral circulante \\
\hline DNA & Ácido desoxirribonucléico \\
\hline EMT & Transição epitélio-mesenquimal \\
\hline HCFMRP & Hospital das Clínicas de Ribeirão Preto \\
\hline HER2 & Receptor 2 do fator de crescimento epidermal humano \\
\hline lincRNA & RNA não codificador longo intergênico \\
\hline IncRNA & RNA não codificador longo \\
\hline MEC & Matriz extracelular \\
\hline MET & Transição mesenquimal-epitelial \\
\hline miRNA & micro RNA \\
\hline MMP & Metaloproteinase de matriz \\
\hline mRNA & RNA mensageiro \\
\hline ncRNA & RNA não codificador \\
\hline PCR & Reação em cadeia da polimerase \\
\hline RE & Receptor de estrógeno \\
\hline RIN & Número de integridade do RNA \\
\hline RNA & Ácido ribonucléico \\
\hline
\end{tabular}


Receptor de progesterona

UTR

Região não traduzida 


\section{LISTA DE SÍMBOLOS}

$\begin{array}{ll}{ }^{\circ} \mathrm{C} & \text { grau celsius } \\ \mathrm{mg} & \text { miligrama } \\ \mathrm{ml} & \text { mililitro } \\ \mathrm{\mu l} & \text { microlitro } \\ \mathrm{ng} & \text { nanograma } \\ \mathrm{nm} & \text { nanômetro } \\ \mathrm{pb} & \text { pares de base } \\ \text { RPM } & \text { rotações por minuto } \\ \% & \text { porcentagem }\end{array}$




\section{SUMÁRIO}

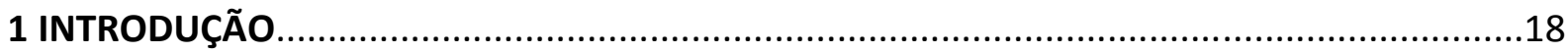

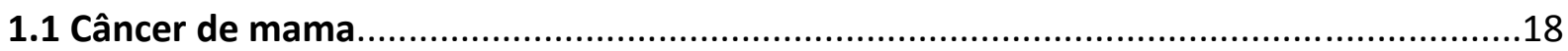

1.1.1 Epidemiologia e aspectos clínicos do câncer de mama ................................................18

1.1.2 Heterogeneidade tumoral no câncer de mama ..............................................................20

1.1.3 Genética e biologia molecular do câncer de mama.......................................................21

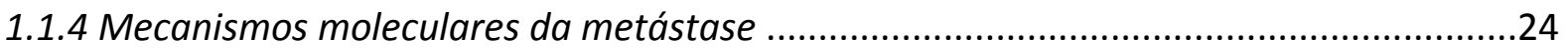

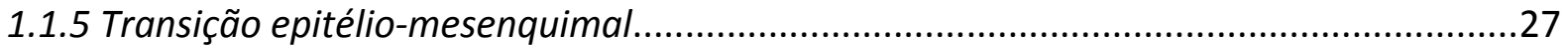

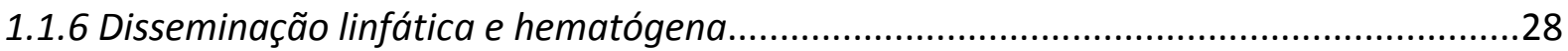

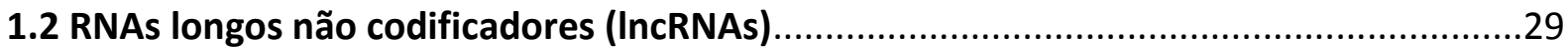

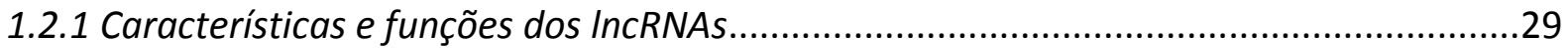

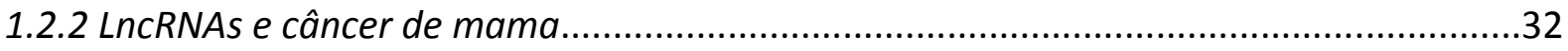

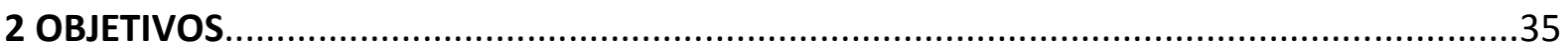

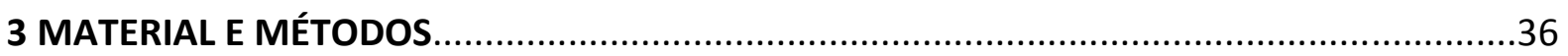

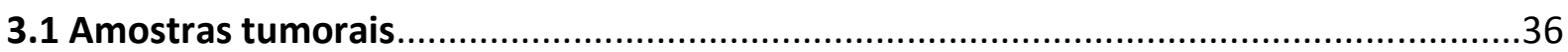

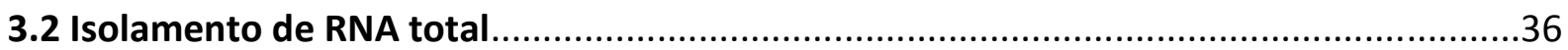

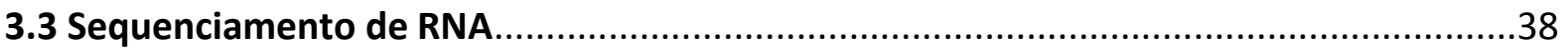

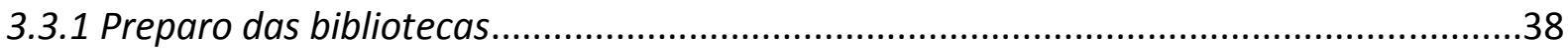

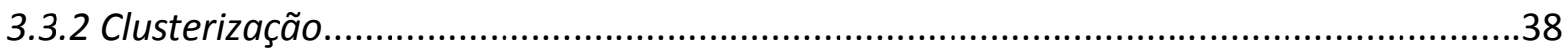

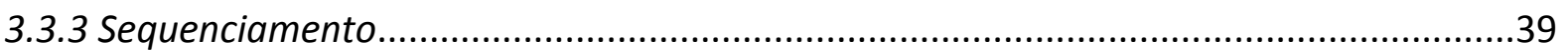

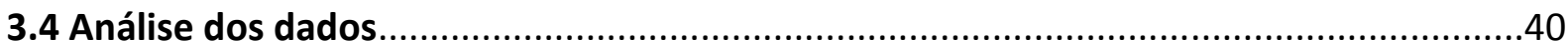

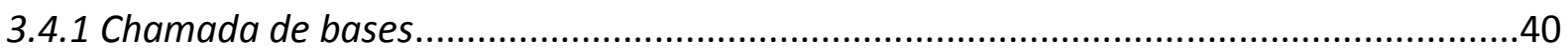




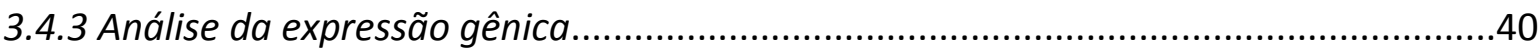

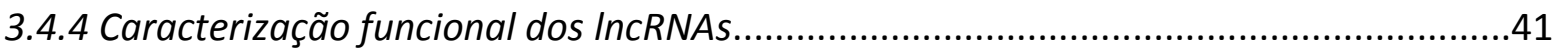

3.5 Validação de expressão de IncRNA por PCR semi-quantitativa.................................41

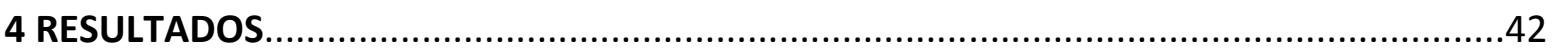

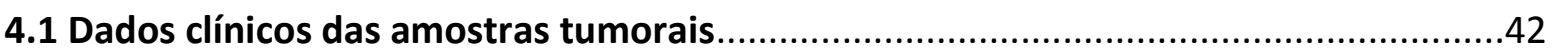

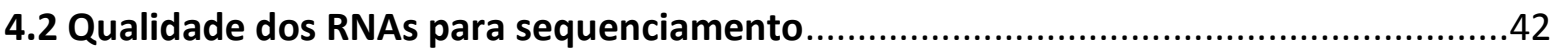

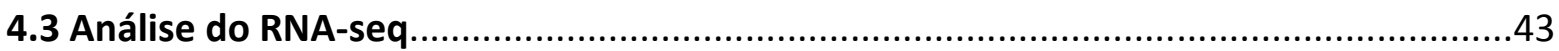

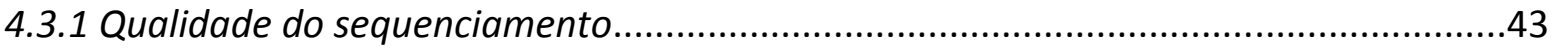

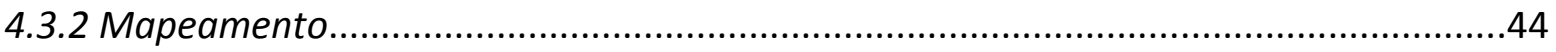

4.3.3 Análise dos IncRNAs expressos nas amostras tumorais..........................................45

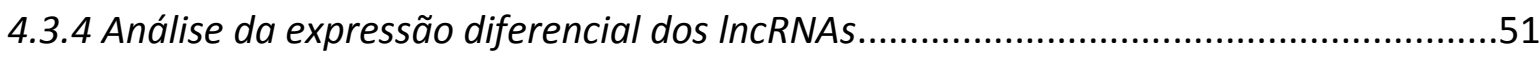

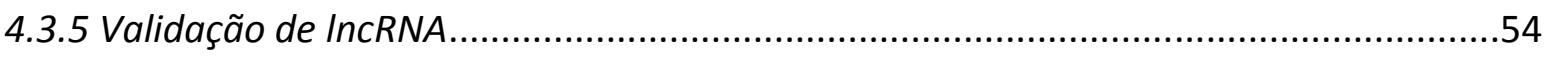

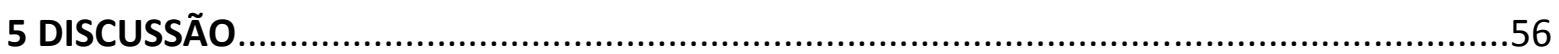

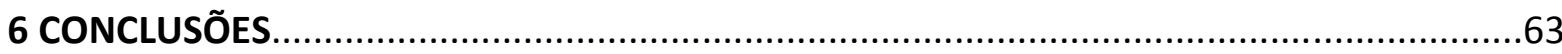

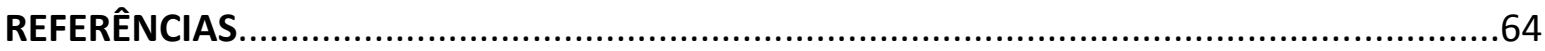

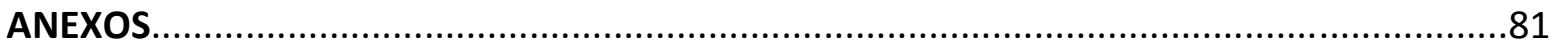




\section{INTRODUÇÃO}

\subsection{Câncer de mama}

\subsubsection{Epidemiologia e aspectos clínicos do câncer de mama}

O câncer de mama é o tipo de câncer mais comum entre as mulheres de todo o mundo, depois do câncer de pele não melanoma, sendo responsável pela morte de mais de 14.200 mulheres em 2013, em contraste com o número de mortes em homens (181) no mesmo ano (INCA, 2016). Mais alarmantes ainda são as previsões do Instituto Nacional do Câncer, que estima o surgimento de 57.960 novos casos no Brasil, e da International Agency for Research on Cancer, que prevê o surgimento de mais de 307.600 novos casos nos Estados Unidos em 2016. Dentre os casos de câncer de mama diagnosticados nos últimos anos, 20\% a $30 \%$ deles podem estar associados à ocorrência de múltiplos fatores de risco, sendo os principais a idade acima de 40 anos, o histórico de doenças da glândula mamária, o histórico de câncer em parentes de primeiro grau, menarca precoce e gravidez tardia (Kamińska et al., 2015). Além dos fatores de risco, a raça/etnia também tem influência importante na incidência desse tipo de câncer, tendo sido observado um maior número de casos em mulheres brancas (Smigal et al., 2006).

O câncer de mama se constitui em um grupo de neoplasias originadas das células epiteliais que revestem os dutos de leite (Polyak, 2011). Se as células cancerosas não passaram pela membrana basal, o câncer é denominado in situ ou não invasivo e pode ser classificado em carcinoma lobular in situ (CLIS) e carcinoma ductal in situ (CDIS) (Sibbering e Courtney, 2016). A principal diferença entre os dois tipos é o padrão de expressão de Ecaderina, que é praticamente ausente no CLIS (Buerguer et al., 2000). Acredita-se que o CDIS seja o precursor do carcinoma ductal invasivo - aquele onde há invasão do tecido adjacente sendo a perda da organização da camada celular mioepitelial e da membrana basal os critérios que definem a transição de um para o outro (Hu, et al., 2008). De uma forma geral, o prognóstico do carcinoma de mama é influenciado pelo estágio do tumor, grau, superexpressão do homólogo 2 do oncogene viral de leucemia eritroblástica aviária v-erb-b2 (ERBB2), e receptores hormonais (Vymetalkova et al., 2015). 
De acordo com o perfil de expressão gênica, o câncer de mama pode ser dividido em cinco subtipos biologicamente distintos: luminal A, luminal B, HER2-enriquecido $\left(\mathrm{HER}^{+}\right)$, basal e mama-normal símile (Liu et al., 2014). Cada um desses grupos apresenta diferentes fatores de risco para a sua incidência, riscos de progressão e sítios preferenciais de metástase (Polyak, 2011). Tanto o $\mathrm{HER2}^{+}$quanto o câncer de mama basal possuem desenvolvimento ruim, sendo que este último é bastante frequente e tende a acometer mulheres mais jovens (Liu et al., 2014). Ambos os subtipos luminais A e B expressam o receptor de estrogênio $\left(\mathrm{RE}^{+}\right)$, porém o tipo $\mathrm{B}$ tem uma evolução relativamente pior, e as características clínicas do câncer de mama luminal A parecem ser mais relevantes para o tempo de sobrevida do paciente e terem o maior poder prognóstico (Liu et al., 2014). Além dos cinco subtipos supracitados, outros já foram descritos, como alguns subgrupos de câncer de mama triplo-negativos (Lehmann et al., 2011). Em 2007, Herschkowitz e colaboradores descreveram um subtipo adicional, denominado claudin-low, caracterizado pela baixa expressão de genes envolvidos em tight junctions e adesão celular. Suas diferenças em relação aos demais subtipos e suas particularidades, porém, só foram melhor descritas recentemente (Sabatier et al., 2014).

Atualmente, o método padrão para triagem e diagnóstico do câncer de mama é a mamografia, onde os principais sinais indicadores da doença são a presença de nódulo espiculado, calcificações pleomórficas agrupadas e área de assimetria focal com distorção do parênquima mamário (Nazário et al., 2015). A escolha da terapia adequada para cada paciente é feita com base nos fatores prognósticos histopatológicos e imunohistoquímicos, sendo primeiramente realizado o tratamento cirúrgico para retirada do tumor, seguindo-se de radioterapia (para tumores maiores de $5 \mathrm{~cm}$ ) (Nazário et al., 2015). Todos os pacientes submetidos a cirurgia para remoção de câncer de mama maligno devem passar por procedimento em nódulo axilar, tanto para fins de estadiamento quanto para tratamento de axila nodo positiva (Sibbering e Courtney, 2016). A quimioterapia é indicada apenas em casos de doença localmente avançada ou metastática, ou quando nos estágios iniciais o tumor mede mais de $2 \mathrm{~cm}$ ou ainda se há comprometimento da axila (Nazário et al., 2015). 0 objetivo da quimioterapia é justamente diminuir o estágio do tumor, tornando-o operável (Sibbering e Courtney, 2016). O tratamento endócrino, por sua vez, é indicado para 
pacientes $\mathrm{RE}^{+}$que não podem ser operados (devido a co-morbidades ou recusa à operação) (Sibbering e Courtney, 2016).

\subsubsection{Heterogeneidade tumoral no câncer de mama}

A mama é um dos poucos órgãos que passa por ciclos de crescimento, diferenciação, regressão e remodelamento durante a vida do organismo (Bissell et al., 2003). A glândula mamária é derivada de células ectodérmicas, formando uma árvore de ductos rudimentares durante a vida intra-uterina, que é induzida a crescer e formar a massa de gordura mamária durante a puberdade (Koren e Betires-Alj, 2015). Já na fase adulta, a mama apresenta hierarquia epitelial e população heterogênea de células-tronco (Visvader e Stingl, 2014), porém no tumor não há necessariamente uma correlação direta entre o fenótipo e a célula de origem (Melchor et al., 2014).

O câncer de mama é caracteristicamente uma doença bastante heterogênea, tanto do ponto de vista morfológico, quanto em relação ao microambiente tumoral, a expressão protéica e ao genoma (Badve et al., 2015), o que dificulta o diagnóstico, o prognóstico e a abordagem terapêutica utilizada (Koren e Betires-Alj, 2015). Existem duas hipóteses para explicar a heterogeneidade intertumoral, que dá origem aos diferentes subtipos de câncer de mama: a primeira é baseada na célula de origem, onde cada tipo de tumor se originaria de um tipo celular; a segunda considera que a célula de origem pode ser a mesma para todos os subtipos, porém o fenótipo de cada um é determinado por eventos genéticos e epigenéticos adquiridos (Polyak, 2007). Esta última hipótese é corroborada por Melchor e cols. (2014), que, em trabalho utilizando modelos murinos geneticamente modificados, demonstraram que a lesão genética inicial é o determinante primordial do perfil molecular do tumor subsequente, sugerindo que a formação tumoral depende dos eventos iniciais da carcinogênese.

A heterogeneidade intratumoral pode ser parcialmente explicada pela teoria da célulatronco cancerosa (CTC), que sugere que uma subpopulação de CTCs pode se auto-renovar e se diferenciar em uma determinada linhagem para originar a massa de células do tumor (Zhang M. et al., 2015). Ela ainda pode ser resultado do acúmulo de mudanças genéticas 
cumulativas nas células-tronco tumorais ou então da combinação do tipo celular que originou o tumor, alterações genéticas e epigenéticas adquiridas, e sinais parácrinos das células circundantes (Polyak, 2007). Em estudo de Zhang e cols. (2015), foi sugerido que a heterogeneidade intratumoral não deve ser exclusiva de diferenças genéticas entre várias subpopulações, mas que modificações epigenéticas devem permitir que essas subpopulações se desenvolvam em células com diferentes potenciais tumorigênicos, e que elas se tornem diferentes tipos celulares, que darão origem a tumores fenotipicamente diferentes.

\subsubsection{Genética e biologia molecular do câncer de mama}

A maioria dos casos de câncer de mama é esporádica, porém 5 a $10 \%$ de todos os casos está relacionada à herança de mutações genéticas e tem como característica o acometimento de mulheres jovens (Amendola e Vieira, 2005). Atualmente, o câncer de mama é considerado hereditário se há pelo menos três casos de câncer de mama/ovário na família, dois casos de carcinoma mamário em parentes próximos antes dos 50 anos e ancestralidade judia Ashkenazi com câncer de mama triplo negativo antes dos 60 anos (Branham et al., 2016). Variantes de suscetibilidade incluem mutações raras de alto risco, variantes mais moderadas, e variantes de suscetibilidade comuns que possuem pouca penetrância (Nickels et al.,2013).

Os genes BRCA1 e BRCA2 são supressores tumorais e cerca de 30\% dos cânceres de mama são atribuídos a mutações nesses genes (Sana e Malik, 2015). A expressão do gene BRCA1 é importante para o processo de reparo do DNA, ativação de pontos de checagem do ciclo celular e manutenção da estabilidade cromossômica (Sotiriou e Pusztai, 2009). De forma similar, a presença na célula do gene BRCA2 não funcional faz com que o reparo de quebras na dupla fita de DNA seja propenso ao erro, levando à instabilidade cromossômica (Sana e Malik, 2015). Além de BRCA1/2, outros genes importantes estão associados com alta penetrância familial do câncer de mama, como o TP53, o gene mais frequentemente alterado nos cânceres humanos (Yadav et al., 2015). Ele é herdado de forma autossômica dominante e mutações nesse gene levam a um risco de aproximadamente $49 \%$ de desenvolvimento de câncer de mama em mulheres com 60 anos (Scalia-Wilbur et al., 2016). 
A proteína p53, codificada pelo gene TP53, é crucial na preservação da integridade genômica, agindo em processos de hipóxia e ativação de oncogenes, além de interagir com proteínas que controlam a morte celular programada (Vymetalkova et al., 2015). Outro gene relevante é o PTEN, um supressor tumoral que, quando perdido em tumores mamários, aumenta a atividade da via PI3K (Liu et al., 2016), que por sua vez está envolvida na regulação do crescimento e da diferenciação celular e do desenvolvimento (Vara et al., 2004). Em trabalho publicado por Bubien et al. (2013), foi encontrado um risco cumulativo de câncer de mama de $77 \%$ aos 70 anos para mulheres com mutações no PTEN.

Entre os genes relacionados com moderada penetrância familial, tem sido observadas mutações de perda de função no PALB2 em 0,6\% a 3,9\% das famílias com histórico de câncer de mama (Antoniou et al., 2014). A proteína de PALB2 interage com as proteínas dos genes BRCA1/2, ativando a resposta de reparo do DNA e garantindo que não haja erros durante a recombinação homóloga - a interrupção dessa interação, geralmente devido a mutações, aumenta significativamente o risco de câncer (Poumpouridou et al., 2015). Aos 70 anos, o risco de desenvolvimento do carcinoma de mama em mulheres portadoras de mutação em PALB2 vai de $33 \%$, para mulheres que não possuem parentes afetados, até $58 \%$ para mulheres com dois parentes de primeiro grau diagnosticados com câncer de mama aos 50 anos (Antoniou et al., 2014). De forma similar, o produto do gene CHEK2 é ativado quando há dano no DNA e interage com outras proteínas, como a dos genes BRCA1 e TP53, interrompendo o ciclo celular (Sheikh et al., 2015; Massink et al., 2015). A anormalidade de CHEK2 deve-se à mutação $1100 *$ delC, que gera um códon de parada prematura (Massink et al., 2015) e aumenta em duas vezes o risco de câncer de mama nos seus portadores (CHEK2 Breast Cancer Case-Control Consortium, 2004). O gene ATM também é atuante no reparo de quebras na dupla fita de DNA e um dos seus papéis é a fosforilação do BRCA1 (Scalia-Wilbur et al., 2016). Mutações em heterozigose em ATM levam a um risco duas vezes maior de desenvolvimento de carcinoma mamário na população em geral, o que chega a ser cinco vezes maior em mulheres com menos de 50 anos de idade (Economopoulou et al., 2015). Juntamente com CHEK2, PALB2 e BRCA1/2, ATM é indicado como um dos melhores candidatos para inclusão em um painel multigênico para câncer de mama, uma vez que esses genes têm alta prevalência e penetrância de mutações patogênicas (Lerner-Ellis et al., 2015). 
Além dos genes de alta e moderada penetrância familial, mutações em outros genes têm sido identificadas, o que pode ajudar na compreensão da herdabilidade do câncer de mama. Em 2015, Michailidou e colaboradores identificaram 15 novas variantes, ajudando a explicar, juntamente com os demais loci, aproximadamente $16 \%$ do risco familial de câncer de mama. No mesmo ano, Aloraifi e cols., em estudo de uma população irlandesa, identificaram novas variantes potencialmente patogênicas em 30 outros genes, o que poderia explicar a etiologia de $35 \%$ do mecanismo de herança dessa doença.

O câncer de mama esporádico, por sua vez, é assim considerado quando as mudanças genéticas acontecem nas células somáticas com o passar do tempo, tendo sido proposto que em um terço desses tumores há redução da expressão do BRCA1, sem que este apresente qualquer mutação (Branham et al., 2016). Apesar disso, já há descrição na literatura de carcinoma de mama esporádico em uma mulher com mutação na linhagem germinativa de BRCA1 (Curtit et al., 2015), o que torna a biologia desse tipo de câncer ainda mais complexa. O gene ATM também possui variantes identificadas em pacientes sem história familiar de câncer de mama, de acordo com um estudo realizado em uma amostra da população brasileira (Mangone et al., 2015). Muitos estudos vêm sendo realizados a fim de melhor compreender as causas do início e da progressão do câncer de mama, incluindo aqueles com RNAs não codificantes, como os micro RNAs (miRNAs) (Danza et al., 2014; Bastos et al., 2014), e aqueles que levam em conta a metilação dos genes (Zhang e Long, 2015; Zhu et al., 2015), demonstrando que as mudanças epigenéticas estão ganhando cada vez mais importância nesse contexto.

O gene HER2, receptor 2 do fator de crescimento epidermal humano, está envolvido com a regulação do crescimento e desenvolvimento da mama normal (Yarden, 2001). Ele está envolvido com crescimento e progressão tumoral e encontra-se amplificado em cerca de $30 \%$ dos cânceres de mama, além de estar positivamente correlacionado com metástase (Li et al., 2004). O produto de HER2 é uma potente oncoproteína que, quando ativada, resulta em transdução de sinal para o núcleo, levando a ativação de genes e à divisão celular. Devido ao seu elevado nível nas células tumorais, baixos níveis nos tecidos normais, localização acessível na superfície celular e seu papel na carcinogênese, HER2 é utilizado com alvo terapêutico, como por exemplo, a utilização de anticorpos monoclonais contra o seu domínio extracelular (Yarden, 2001). Quimiocinas também possuem papel importante 
no câncer de mama, como o fator $1 \alpha$ derivado de célula estromal (SDF-1 $\alpha$, também conhecida como CXCL12), cuja interação com seu receptor (CXCR4) leva à polimerização de actina e formação de pseudopodia em câncer de mama, induzindo respostas quimiotáticas e invasivas (Müller et al., 2001). Já foi demonstrado que HER2 aumenta a expressão do receptor de quimiocina CXCR4, por meio do aumento da taxa traducional, o que é necessário para invasão in vitro induzida por SDF-1 $\alpha$ (Li et al., 2004).

\subsubsection{Mecanismos moleculares da metástase}

A metástase é a diferença fundamental entre o crescimento celular benigno e o maligno, representando o principal problema clínico do câncer (Pecorino, 2012). Tal mecanismo consiste no desprendimento de células do tumor primário que podem invadir os tecidos adjacentes e colonizar sítios distantes, e é considerado uma das marcas do câncer, por ser característico de todos os tipos de tumores humanos (Hanahan e Weinberg, 2000). A metástase é responsável pela morte de aproximadamente $90 \%$ dos pacientes com câncer (Reymond et al., 2013), e esse alto índice é reflexo da obstrução física, competição com células normais por nutrientes e oxigênio, além de interferência da função normal do órgão devido ao espalhamento das células cancerosas (Pecorino, 2012). Apesar do alto índice de mortalidade associado à metástase, esse processo é, de uma forma geral, ineficiente, uma vez que as células tumorais falham em executar um ou mais passos necessários para a cascata metastática (Labelle e Hynes, 2012).

Classicamente, a metástase pode ser dividida em alguns passos básicos sequenciais: invasão local, intravasamento, circulação, extravasamento e colonização (Nguyen et al., 2009). As células podem migrar em conjunto ou individualmente, sendo as estratégias de migração celular individual classificadas como amebóides ou mesenquimais (Brábek et al., 2010). Durante a invasão e a migração, células cancerosas se destacam do tumor primário e invadem o tecido adjacente saudável, através da secreção de enzimas líticas que degradam a matriz extracelular (MEC) (Leber e Efferth, 2009). Dentre elas, destacam-se as metaloproteinases de matriz (MMPs), que exercem atividade proteolítica, facilitando a metástase, além de tornarem fatores de crescimento mais acessíveis às células cancerosas e de modularem interações célula-célula e célula-MEC (Gialeli et al., 2011). No contexto do 
câncer de mama, a transcrição de MMP-1 e MMP-13, por exemplo, é aumentada como consequência de mutação no gene supressor tumoral p53, além de muitas outras MMPs estarem associadas com as demais fases de progressão tumoral (Koujan et al., 2015). Ainda nessa etapa de invasão, acredita-se que o mecanismo de transição epitélio-mesenquimal (EMT) tem um importante papel na conversão das células tumorais em uma população migratória (Bravo-Cordero et al., 2012).

O intravasamento consiste na entrada da célula tumoral em um vaso sanguíneo ou linfático, o que requer a aderência da célula cancerosa à face estromal do vaso, o rompimento das junções endoteliais e a migração até o lúmen do vaso (Pecorino, 2012). Alguns fatores, como o fator de crescimento transformante $\beta$ (TGF- $\beta$ ) e o fator de crescimento endotelial vascular (VEGF), diminuem a função da barreira endotelial, o que aumenta o número de células que entram no vaso (Reymond et al., 2013). Em trabalho publicado em 2014, Pignatelli e colaboradores demonstraram que células de câncer de mama primário que expressam uma isoforma associada a invasão de Mena (Mena ${ }^{\text {INV }}$ ), proteína regulatória do citoesqueleto, são mais propensas à migração transendotelial, promovida pela presença de macrófagos. Porém, ainda há discussão sobre o intravasamento ser um processo passivo ou ativo e se as células tumorais atravessam a barreira endotelial pelas junções célula-célula (paracelular) ou pelo corpo celular (transcelular) (Zervantonakis et al., 2012). A maioria das células cancerosas parece adotar a rota paracelular in vitro, porém ainda não é claro qual rota seria adotada in vivo e se a escolha de um tipo de migração ou de outro depende do leito vascular ou do tipo de câncer (Reymond et al., 2013). Alternativamente, em uma linhagem celular de câncer de mama, Khuon e cols. (2010) demonstraram que as células tumorais invasivas medeiam o intravasamento transcelular ativo, pela ativação local de miosina endotelial.

Após o intravasamento, as células do tumor alcançam a circulação, sendo então denominadas células tumorais circulantes (CTCs), onde ficam expostas ao fluxo sanguíneo e vulneráveis à morte celular induzida por estresse ou por células imunes (Labelle e Hynes, 2012). Em parte, o sucesso da sobrevivência das CTCs na circulação se deve à ação de plaquetas e fibrinogênio, que impedem a remoção intravascular das células tumorais pelas células natural killers (Palumbo et al., 2005), uma vez que as plaquetas se agregam em torno das células cancerosas - estas, por sua vez, aumentam a coagulação das plaquetas, o que 
aumenta a metástase (Reymond et al., 2013). As células tumorais podem ativar as plaquetas pela produção de trombina, induzida pelo fator tecidual associado ao tumor, que está altamente expresso em sítios de hipóxia, como os encontrados no tumor (Konstantopoulos e Thomas, 2009). Tipicamente, as CTCs não permanecem muito tempo na corrente sanguínea, inclusive a maioria das células de carcinoma tem diâmetro muito grande para conseguir passar por pequenos capilares e muitas delas ficam presas no primeiro capilar que encontram, o que ocorre minutos após entrarem na circulação (Labelle e Hynes, 2012).

O extravasamento é o passo menos conhecido da cascata metastática, porém já foi demonstrado que é um processo altamente dinâmico e coordenado e que requer a projeção de protrusões pela camada endotelial (Leong et al., 2014). Além disso, estudo em linhagens celulares mostrou que a superexpressão dos genes Twist e VEGFA aumentou significativamente o número de células tumorais extravasantes, e que estas induzem o agrupamento das células endoteliais e o remodelamento das suas junções celulares no sítio de extravasamento (Stoletov et al., 2010). Kanada e cols. (2014), em estudo com peixezebra, sugeriram que a passagem das células tumorais da circulação para o tecido adjacente pode ocorrer de dois modos: ativamente, pela invasão da parede do vaso; e passivamente, onde massas de células quiescentes seriam eventualmente recobertas por uma nova lâmina de células endoteliais na parede do vaso e haveria, simultaneamente, o gradual desaparecimento da camada endotelial original, permitindo que o grupo de células cancerosas se espalhe pelo tecido fora do vaso.

O próximo e último passo da cascata metastática é a colonização, que se refere à formação de um novo tumor. As células que extravasaram tanto podem morrer, quanto entrar em dormência ou formar colônias pela proliferação contínua - o que vai determinar o destino celular são as interações das células tumorais com os elementos do parênquima do órgão alvo (como células estromais), a vascularização e a vigilância imune (Shibue e Weinberg, 2011). O acúmulo de neutrófilos, por exemplo, age como um nicho prémetastático no tecido alvo para a disseminação metastática (Wculek e Malanchi, 2015). A habilidade das células tumorais de formarem colônias em órgãos distantes também depende em grande parte da sua capacidade de proliferação, o que requer interações de adesão de integrinas com a matriz extracelular, já tendo sido demonstrado que a fibrina é eficiente no suporte à formação de colônias (Knowles et al., 2015). 


\subsubsection{Transição epitélio-mesenquimal}

A transição epitélio-mesenquimal $(E M T)$ é o processo pelo qual as células epiteliais perdem as suas junções e suas polaridades apico-basais, reorganizam seus citoesqueletos, sofrem mudanças nos seus programas de sinalização que definem seus formatos e reprogramam sua expressão gênica, aumentando a sua motilidade e desenvolvendo um fenótipo invasivo (Lamouille et al., 2014). Esse processo simula o evento de gastrulação normal do desenvolvimento e pode ser classificado em três subtipos: o primeiro está associado com o desenvolvimento embrionário original e também ocorre durante o crescimento pós-natal; o segundo subtipo é iniciado em resposta a ferimentos e gera fibroblastos para reconstruir tecidos feridos; o terceiro é justamente o subtipo oncogênico, que recapitula características típicas da EMT do desenvolvimento, porém de forma menos ordenada e coordenada (Samatov et al., 2013).

A perda da expressão de E-caderina é considerado um evento fundamental da $E M T$, assim como a perda da polaridade celular (Thiery et al., 2009). A mudança na expressão de genes relacionados às junções aderentes previne que haja formação de novo de junções célula-célula e resulta na perda da função da barreira epitelial (Lamouille et al., 2014). A reorganização do citoesqueleto, por sua vez, permite que a célula adquira uma motilidade direcional, gerando projeções de membrana que facilitam o movimento celular e que possuem função proteolítica, o que leva à degradação da matriz extracelular e facilita a invasão (Lamouille et al., 2014).

A ativação do programa $E M T$ nas células cancerosas facilita a progressão do câncer por diversos mecanismos: iniciando processos invasivos e antiapoptóticos que levam à metástase; gerando células estromais ativadas que levam à progressão do câncer por alterações bioquímicas e estruturais no microambiente tumoral; e estimulando uma maior malignidade associada ao fenótipo de célula-tronco cancerosa (Nisticò et al., 2012). A regulação da EMT conta ainda com o envolvimento de diversos fatores de transcrição, dentre os quais o ZEB1, ZEB2, Snail, Slug e Twist são os mais bem caracterizados (Samatov et al., 2013). 
Um fato interessante, é que os tumores metastáticos apresentam um aumento na expressão de E-caderina, quando comparada com a expressão aberrante ou perda da sua expressão nos tumores primários, levando-os a se assemelharem ao fenótipo epitelial do tumor de origem (Chao et al., 2010). Tal característica deve-se em grande parte ao processo inverso da $E M T$, a transição mesenquimal-epitelial $(M E T)$, que é crítica para os últimos estágios da cascata metastática (Yao et al., 2011).

\subsubsection{Disseminação linfática e hematógena}

A disseminação metastática pode ocorrer pelo intravasamento das células tumorais em vasos linfáticos ou sanguíneos, sendo a decisão por um ou outro caminho influenciada por restrições físicas impostas aos tumores invasivos, assim como pela acessibilidade das vasculaturas sanguínea e linfática (Wong e Hynes, 2006). A maioria dos cânceres epiteliais primeiramente desenvolve metástase pela dispersão via vasos linfáticos até seus linfonodos de drenagem - inclusive, a detecção de metástases no linfonodo sentinela (primeiro linfonodo que o tumor atinge) tem grandes implicações prognósticas (Karaman e Detmar, 2014).

Os vasos linfáticos são estruturas de fundo cego perfeitamente adaptadas para captação de fluido, partículas e células, e são compostas de uma única camada endotelial e uma membrana basal descontínua (Nathanson, 2003; Rahman e Mohammed, 2015). Eles transportam o excesso de fluido extravascular, que passa pelos linfonodos e retorna para o sistema venoso, o que torna os linfonodos que estão drenando o tumor primário bastante propensos a desenvolver um tumor secundário (Rizwan et al., 2015). Além disso, os linfonodos possuem sua própria vascularização, o que possibilita a sua invasão por células tumorais que escapam dos vasos sanguíneos (Rizwan et al., 2015). Diferentemente destes, os vasos linfáticos são altamente permeáveis, o que os torna superiores em permitir a disseminação das células tumorais, sendo, inclusive, a via preferencial de metástase de tumores de mama (Rahman e Mohammed, 2015).

Os vasos sanguíneos, por sua vez, possuem junções interendoteliais típicas, assim como camadas circundantes de pericitos e músculo liso, além de membranas basais, o que 
os tornam menos permeáveis às células tumorais (Wong e Hynes, 2006). Apesar disso, os novos vasos gerados por estímulo do tumor são mais propensos à invasão pelas células tumorais, além de serem mais tortuosos, o que permite um acesso mais fácil se comparado aos vasos de tecidos saudáveis (Pecorino, 2012). Os pericitos são importantes para os vasos sanguíneos, pois fornecem a eles suporte estrutural, já tendo sido demonstrado que uma baixa cobertura por essas células está significativamente associada com a presença de metástases distantes (Cooke et al., 2012).

\subsection{RNAs longos não codificadores (IncRNAs)}

\subsubsection{Características e funções dos IncRNAs}

Diversos genes codificadores de proteína já são utilizados como biomarcadores em diversos tipos de câncer (Henry e Haynes, 2012; Sana e Malik, 2015), porém eles compõem menos de $3 \%$ de todo o genoma, enquanto mais de $85 \%$ dele é transcrito (Hangauer et al., 2013). Estudos já indicaram a existência de milhares de transcritos não codificadores expressos no genoma de mamíferos e que esses transcritos compreendem uma rede complexa a partir de ambas as fitas do DNA (Mattick, 2005). Além disso, um número cada vez maior de estudos vem mostrando que processos epigenéticos cooperam com os processos genéticos em todos os estágios do desenvolvimento desse grupo de doenças (Jones e Baylin, 2007). Nesse contexto, os IncRNAs oferecem vantagens sobre as proteínas em algumas formas de regulação epigenética, como a capacidade de se prenderem ao sítio de transcrição, permitindo uma especificidade regulatória (Lee, 2012).

Os IncRNAs são definidos como moléculas de RNA não codificadoras de proteínas maiores que $200 \mathrm{nt}$, que podem ou não ser poliadeniladas e que podem ser encontradas tanto no núcleo quanto no citosol (Shi et al., 2013). Eles constituem um grupo bastante heterogêneo de RNAs, o que os permite cobrir um amplo espectro de funções celulares e moleculares pelos seus diferentes modos de ação (Gutschner e Diederichs, 2012). O modo como essas moléculas são transcritas e processadas é similar ao dos RNAs codificadores de proteína: a maioria delas é transcrita pela RNA polimerase II (algumas são transcritas pela RNA polimerase III); a maioria é processada, poliadenilada e tem a adição do cap-5'; e 
grande parte delas tem uma sequência promotora proximal altamente conservada, éxons, íntrons e estruturas secundárias (Nie et al., 2012). Uma característica importante dos IncRNAs é que eles geralmente são expressos de maneira específica, quer seja em relação a uma doença, um tecido ou um estágio do desenvolvimento, o que os torna moléculas atrativas como alvos terapêuticos (Gutschner e Diederichs, 2012).

Os IncRNAs podem ser classificados com base em diferentes critérios, como por exemplo: no tamanho do transcrito; na associação ou na semelhança com genes codificadores de proteínas; e na expressão em diferentes estados biológicos (St. Laurent et al., 2015). Genericamente, os IncRNAs são classificados com base nas suas origens, uma vez que suas funções são difíceis de serem estudadas (Baker, 2011). O consórcio GENCODE, englobado pelo projeto ENCODE, é o maior catálogo de anotação de IncRNAs humanos e classifica esses transcritos com base na sua localização em relação a genes codificadores de proteína (Figura 1): RNAs antisenso são aqueles que interceptam qualquer éxon de um lócus codificador de proteína na fita oposta, ou que possuem evidência de regulação antisenso de um gene codificador de proteína; RNAs longos intergênicos (lincRNAs), como o próprio nome diz, são aqueles provenientes de loci de RNAs não codificadores intergênicos de comprimento maior que $200 \mathrm{pb}$; os transcritos senso sobrepostos contêm um gene codificador dentro de um íntron na mesma fita; IncRNAs intrônicos, por sua vez, estão contidos dentro de um íntron de um gene codificador de proteína, mas não interceptam nenhum éxon; e os transcritos processados são aqueles que não contêm uma janela aberta de leitura (do inglês open reading frame - ORF) e que não podem ser alocados em nenhuma das outras categorias (Derrien et al., 2012).

Em 2010, Khachane e Harrison propuseram que transcritos que surgem de partes de genes codificadores de proteína, como por exemplo, aqueles compostos somente de regiões não traduzidas (UTR) ou que incluem íntrons retidos, fossem também incluídos na categoria de IncRNAs. Recentemente, Braunschweig e cols. (2014) demonstraram que grande parcela dos genes multiexônicos contém um ou mais íntrons retidos, os quais encontram-se enriquecidos em regiões não traduzidas e RNAs não codificantes. Eles são significativamente associados com alto conteúdo CG, comprimento reduzido e sítios de splicing 5' e 3' relativamente fracos. $\mathrm{O}$ quanto as sequências dos sítios de splicing divergem da sequência consenso determina se os mesmos são fortes ou fracos, e suas posições relativas geram 
diferentes modos de splicing alternativo, como a retenção de íntrons alternativos (Kornblihtt et al., 2013).

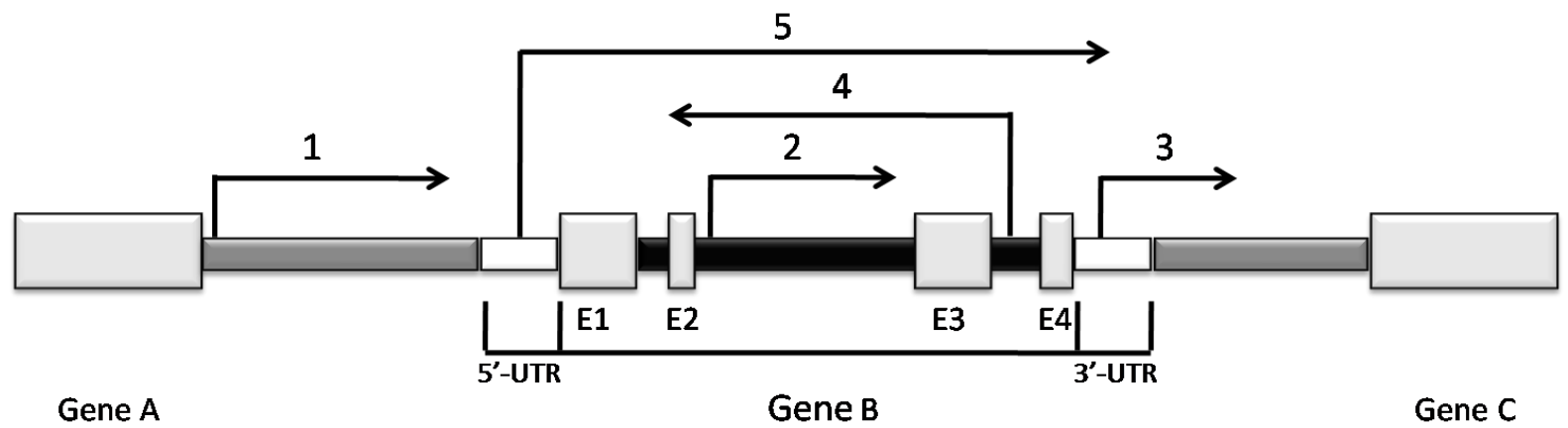

1: lincRNA

2: senso intrônico

3: sobreposto a $3^{\prime}$

4: antisenso

5: senso sobreposto

Figura 1 - LncRNAs em relação a genes codificadores de proteínas e suas denominações. E, éxon; UTR, região não traduzida.

Os IncRNAs podem atuar em trans, ou seja, regulando a expressão de genes localizados em domínios cromossômicos distantes ou mesmo em outros cromossomos, ou podem atuar em cis, quando são transcritos do mesmo lócus que seus genes alvo (Guil e Esteller, 2012). Um dos seus possíveis modos de ação é por interferência da transcrição, que pode ser positiva ou negativa (Ard et al., 2013). Eles também podem atuar como guias para o ancoramento de modificadores de cromatina, para alvejar regiões genômicas, ou como chamarizes para sequestrar modificadores de cromatina de sítios específicos do genoma (Han e Chang 2015). Há evidências de que os IncRNAs possuem a capacidade de atuar como esponjas de micro RNAs (miRNAs), afetando a expressão dos alvos desses miRNAs (Kallen et al., 2013), como reguladores pós-transcricionais, influenciando o splicing alternativo de mRNAs precursores, como precursores de pequenos RNAs, como estabilizadores de mRNA (Quan et al., 2015) e ainda podem agir como moléculas sinal (quando as células sofrem um determinado estímulo, os IncRNAs vão representar uma especificidade tecidual correspondente) (Malih et al., 2015). 


\subsubsection{LncRNAs e câncer de mama}

Assim como os genes codificadores de proteínas, os IncRNAs podem participar na progressão do câncer como oncogenes ou supressores tumorais (Malih et al., 2015). Alguns deles já foram diretamente associados à iniciação e ao desenvolvimento do câncer de mama, como H19, HOTAIR, MALAT1, LSINCT5, ZFAS1 e UCA1 (Vikram et al., 2014), como pode ser exemplificado na figura 2.

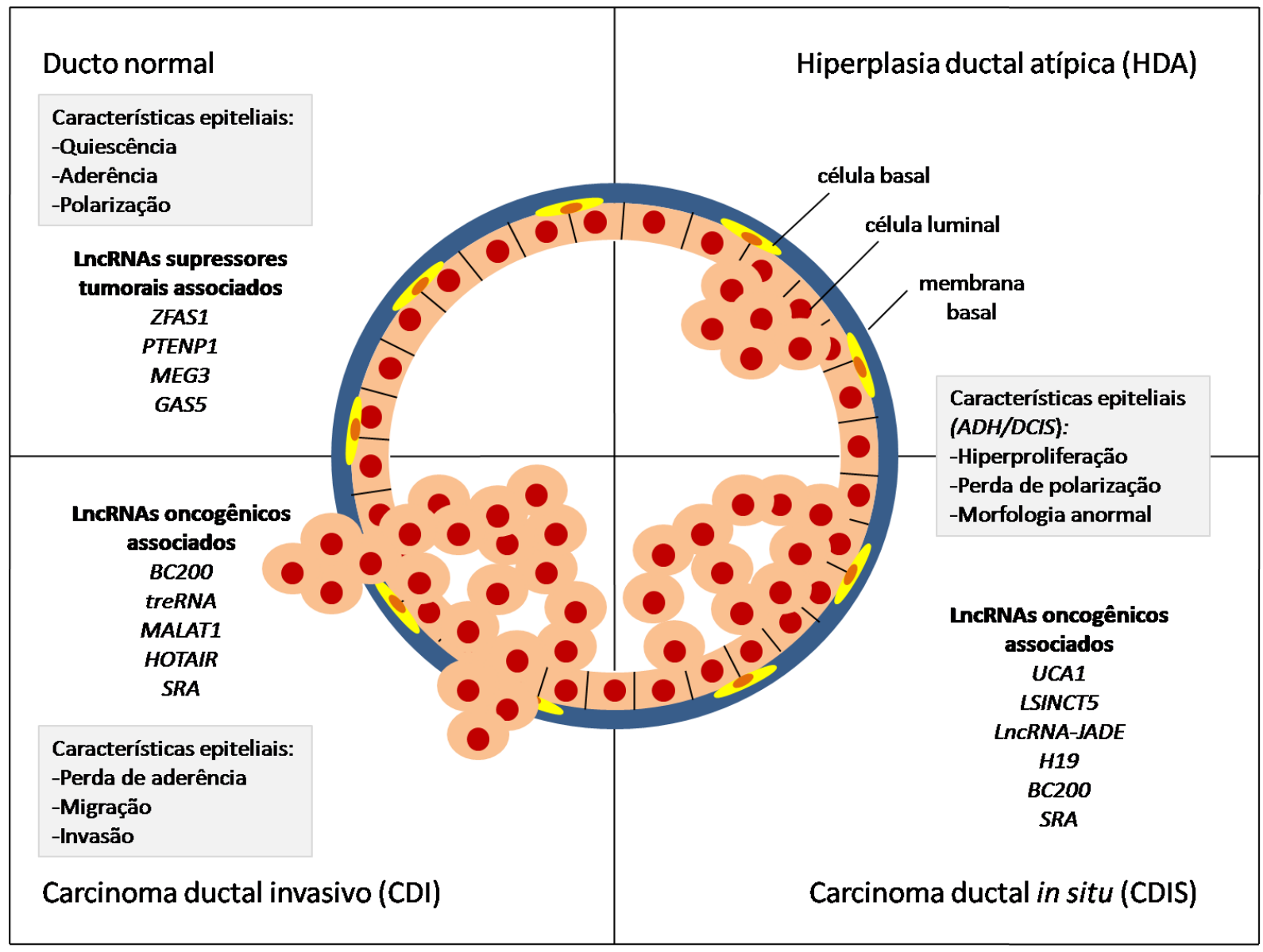

Figura 2 - Visão geral da progressão do câncer de mama. O esquema retrata uma sessão transversal de um ducto mamário dividido em quadrantes que representam cada estágio da progressão do ducto normal até o IDC. Características epiteliais e potenciais IncRNAs associados com cada fase também são mostrados (modificada de Shore e Rosen, 2014).

O IncRNA H19 foi primeiramente descrito em 1990, em trabalho realizado por Brannan e colaboradores, no qual foi identificado que a função do gene H19 não era a de síntese protéica e que seu produto deveria atuar como um RNA. Posteriormente foi demonstrado que ele poderia servir como um transcrito primário de miRNA (Cai e Cullen, 2007), além de estar envolvido na promoção da progressão do ciclo celular em células de câncer de mama (Berteaux et al., 2005). Ele encontra-se superexpresso em mais de $70 \%$ de adenocarcinomas 
mamários e sua expressão em células de câncer de mama aumenta o crescimento independente de ancoragem, além de diminuir o tempo de aparecimento de tumor in vivo (Lottin et al., 2002).

O HOTAIR é transcrito a partir da fita antisenso do gene HoxC e é capaz de interagir com o complexo repressivo policombe 2 (PRC2) - uma histona metiltransferase que gera silenciamento epigenético - guiando-o para diferentes sítios no genoma (Hajjari e Salavaty, 2015), sendo o primeiro IncRNA implicado na modulação do estado da cromatina em trans (Bergmann e Spector, 2014). Esse IncRNA está altamente expresso em tumores de mama primários e metástase, o que o torna um potencial preditor de eventuais metástases e morte (Malih et al., 2015) e é um dos componentes essenciais da transição epitéliomesenquimal em linhagem celular de câncer de mama (Pádua Alves et al., 2013). O promotor de HOTAIR possui múltiplos elementos funcionais de resposta a estrógeno, o qual induz a sua transcrição, e uma de suas formas de atuação no carcinoma mamário é pela competição por ligação com genes supressores tumorais, como o BRCA1 (Hansji et al., 2014).

Envolvido na regulação do splicing alternativo de mRNAs precursores, o MALAT1 é um dos IncRNAs mais abundantes (Arun et al., 2016). Recentemente, o aumento da sua expressão foi sugerido como vital para a metástase em câncer de mama, uma vez que promove migração e invasão celular in vitro, além de funcionar como um RNA endógeno competitivo (ceRNA), induzindo EMT (Chou et al., 2016). Também já foi demonstrado que MALAT1 possui alta expressão em tecidos de câncer de mama triplo negativo, quando comparado com tecidos mamários adjacentes, assim como em linhagens celulares triplo negativas quando comparadas com linhagem de mama normal (Li, L. et al., 2016).

O LSINCT5, descrito em 2010 por Silva e cols., pertence a um grupo de IncRNAs induzidos por estresse e é um dos que se encontra superexpresso em linhagens celulares de câncer de mama. Esse transcrito está envolvido na proliferação celular e a diminuição da sua expressão está associada com a alteração da expressão de genes de quinases, transporte de membrana, associados à carcinogênese, motilidade e estresse (Silva et al., 2011).

O ZFAS1 é um IncRNA que encontra-se expresso em diversos tecidos, porém seus maiores níveis de expressão são encontrados em mama, onde contribui para o desenvolvimento da glândula mamária (Hansji et al., 2014). Ele atua na regulação da via 
intracelular da proliferação e produção de leite e também na diminuição da proliferação e da diferenciação das células do epitélio mamário, o que sugere a sua função como supressor tumoral (Askarian-Amiri et al., 2011). No sentido contrário, o IncRNA UCA1 é necessário para manter a atividade tumorigênica em células de câncer de mama metastático (Hiemer et al., 2014). Isso pode ser decorrente da expressão inversa em relação ao micro RNA 143 (miR143), já que a superexpressão de UCA1 diminui a expressão do miR-143, que por sua vez está relacionado com supressão de proliferação e invasão de células do câncer de mama (Tuo et al., 2015).

Em trabalho recente, Su e cols. (2014) extraíram dados de sequenciamento de RNA (RNAseq) de amostras de câncer de mama do TCGA e traçaram um perfil de IncRNAs expressos potencialmente relevantes para essa doença. A partir dos níveis de expressão dos transcritos, o grupo de pesquisadores identificou a ocorrência de quatro subgrupos: grupo I, relacionado ao subtipo basal-símile de câncer de mama; grupo II, correspondente ao subtipo HER2; e os grupos III e IV, relacionados aos subtipos luminal A e B. Esses resultados revelam que o câncer de mama também pode ser caracterizado molecularmente a partir da avaliação da expressão dos IncRNAs. Com base nessas informações e no recente trabalho publicado pelo nosso grupo, onde foi demonstrado que o IncRNA HOTAIR é requerido para a transição epitélio-mesenquimal em linhagem celular de câncer de mama (Pádua Alves et al., 2013), hipotetizamos que tumores primários de mama e suas respectivas metástases possuem perfis de expressão de IncRNAs que podem tanto caracterizar ambos os tipos tumorais quanto sugerir possíveis moléculas envolvidas com o mecanismo de metástase do câncer. 


\section{OBJETIVOS}

\subsection{Objetivo geral}

Identificar novos IncRNAs associados com tumores metastáticos.

\subsection{Objetivos específicos}

2.2.1 Determinar o perfil de expressão de IncRNAs de tumor de mama metastático em cérebro e em linfonodo;

2.1.2 Classificar funcionalmente os IncRNAs preferencialmente expressos nos tumores metastáticos;

2.1.3 Selecionar IncRNAs potencialmente envolvidos com a metástase. 


\section{MATERIAL E MÉTODOS}

\subsection{Amostras tumorais}

Amostras de tumores primários de mama de 20 pacientes, juntamente com seus correspondentes metastáticos em linfonodo e cérebro (Figura 3), foram obtidas junto ao Banco de Tumores e ao Banco de Tumores de Mama do Hospital das Clínicas de Ribeirão Preto da Universidade de São Paulo. Os tumores, coletados entre os anos de 2008 e 2014, foram imediatamente congelados em nitrogênio líquido e armazenados a $-80{ }^{\circ} \mathrm{C}$. Todas as amostras possuem o Termo de Consentimento Livre e Esclarecido (TCLE) devidamente assinado pelos pacientes e foram submetidas a análise histopatológica . O projeto foi aprovado pelo Comitê de Ética em Pesquisa do HCFMRP/USP (no 829151/2014).

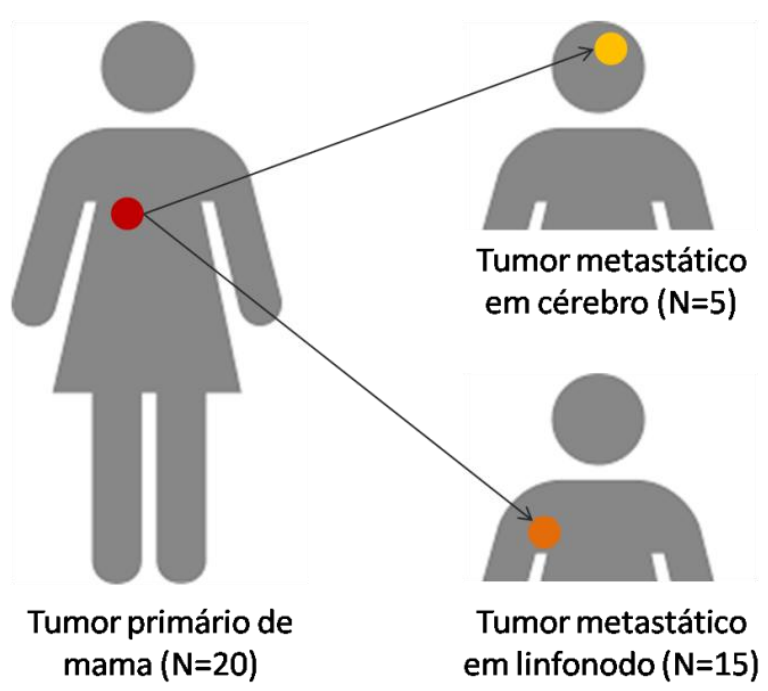

Figura 3 - Amostras tumorais primárias e metastáticas obtidas para o presente estudo.

\subsection{Isolamento de RNA total}

Para extração do RNA, foram retirados fragmentos de aproximadamente $30 \mathrm{mg}$ das amostras tumorais, os quais foram manualmente macerados utilizando pistilos esterilizados e descontaminados. Foi adicionado nitrogênio líquido aos tecidos para impedir o descongelamento durante a maceração e todo o processo foi realizado em gelo seco. Após a maceração, foi adicionado $1 \mathrm{ml}$ de Trizol (Thermo Fischer Sientific, Waltham, MA, USA) em 
cada amostra, a fim de romper as membranas celulares, sendo cada uma então ressuspendida vigorosamente utilizando micropipeta.

Os tecidos em Trizol foram transferidos para tubos de 1,5 ml livres de RNase e adicionou-se $200 \mu \mathrm{l}$ de clorofórmio para separação da fase orgânica da aquosa, seguindo-se de homogeneização por vortex e centrifugação a 13.200 RPM por 15 minutos a $4{ }^{\circ} \mathrm{C}$. A fase aquosa foi coletada e transferida para um novo tubo de 1,5 ml livre de RNase (a fase orgânica foi estocada a $-80^{\circ} \mathrm{C}$ ) e a ela adicionou-se $500 \mu \mathrm{l}$ de isopropanol, para precipitação do RNA, sendo os tubos homogeneizados por inversão incubados em temperatura ambiente por 15 minutos, ao que se seguiu centrifugação a 13.200 RPM por 10 minutos a $4{ }^{\circ} \mathrm{C}$. A fase aquosa foi descartada, $1 \mathrm{ml}$ de etanol 75\% gelado foi adicionado e o tubo foi agitado por 10 segundos em vortex para lavagem do botão de RNA. Após centrifugação a 10.000 RPM por 5 minutos a $4{ }^{\circ} \mathrm{C}$, o sobrenadante foi descartado e o RNA foi lavado com etanol $75 \%$ novamente e centrifugado. A fase aquosa foi descartada e o excesso de etanol foi cuidadosamente retirado com o auxílio de micropipeta. Por fim, adicionou-se água ultrapura para ressuspender o botão de RNA (mínimo de $13 \mu \mathrm{l}$ ) e os tubos foram estocados a $-80^{\circ} \mathrm{C}$.

A quantificação do RNA foi realizada em espectrofotômetro NanoDrop (Thermo Fischer Sientific, Waltham, MA, USA). Taxas de absorbância a $260 \mathrm{~nm}$ e $280 \mathrm{~nm}$ (utilizada para medir a pureza do RNA) e a $260 \mathrm{~nm}$ e $230 \mathrm{~nm}$ (utilizada para uma medida secundária da pureza) entre 1.7 e 2.0 e entre 1.8 e 2.2, respectivamente, foram utilizadas para avaliação da qualidade da extração. A qualidade do RNA foi acessada com o Bioanalyzer 2100 (Agilent Technologies, Santa Clara, CA, USA), que realiza a eletroforese em gel em um chip e que utiliza o Número de Integridade do RNA (do inglês RNA Integity Number - RIN) para descrever a integridade da amostra. Essa ferramenta leva em conta todo o perfil eletroforético e classifica o RNA de acordo com um sistema numérico de 1 a 10, sendo 1 o perfil mais degradado e 10 o mais intacto. Amostras pareadas, com RIN igual ou maior que 6, foram selecionadas para sequenciamento. 


\subsection{Sequenciamento de RNA}

\subsubsection{Preparo das bibliotecas}

A fim de obter o perfil dos transcritos expressos e de identificar novos transcritos nas amostras tumorais, foi realizado o sequenciamento do RNA total das mesmas pela técnica de RNA-Seq. Foram utilizados 300 ng de RNA para o preparo das amostras, que foi realizado com o TruSeq Stranded Total RNA LT Sample Prep Kit (Illumina Inc.,San Diego, CA, USA), de acordo com o protocolo do fabricante. Primeiramente, o RNA ribossômico ( $r$ RNA) foi removido do RNA total por oligos alvo-específicos biotinilados combinados com esferas de remoção de rRNA citoplasmático Ribo-Zero Gold. Após a purificação, o RNA foi fragmentado em segmentos de 200 a 500 pb, utilizando cátions divalentes sob alta temperatura. Os fragmentos foram então utilizados para síntese da primeira fita de DNA complementar (cDNA), usando a enzima transcriptase reversa e primers randômicos, seguindo-se a síntese da segunda fita, onde foram utilizadas as enzimas DNA Polimerase I e RNase H (ribonuclease que degrada a fita de RNA em híbridos DNA-RNA). Após a síntese do cDNA, uma única base adenina (A) foi adicionada a cada fragmento e em sequência foi feita a ligação dos adaptadores. Os produtos foram então purificados e enriquecidos por Reação em Cadeia da Polimerase (PCR) para geração das bibliotecas finais de cDNA. As mesmas foram quantificadas por PCR quantitativa (qPCR) e a qualidade foi avaliada com o Bioanalyzer 2100 (Agilent Technologies, EUA).

\subsubsection{Clusterização}

A geração de clusters foi realizada utilizado o TruSeq Cluster Generation Kit v5 (Illumina Inc.), de acordo com instruções do fabricante, e consistiu na amplificação das bibliotecas de cDNA, produzindo agrupamentos clonais para subsequente sequenciamento. A clusterização ocorreu no cBot (Illumina, Inc.) em célula de fluxo contendo 8 faixas, que permitem a análise simultânea das amostras. As bibliotecas foram colocadas na célula de fluxo, onde se hibridizaram à camada de oligonucleotídeos imobilizados da superfície da célula, sendo em seguida copiados por uma DNA polimerase de alta fidelidade. Os moldes iniciais foram então desnaturados, deixando apenas as cópias imobilizadas na superfície da célula de fluxo. Em 
seguida, essas cópias foram amplificadas por amplificação em ponte, onde os moldes se curvam para se hibridizar com oligonucleotídeos adjacentes presentes na camada superficial (Figura 4). Pontes de DNA dupla fita (dsDNA) foram formadas a partir da cópia desses moldes pela DNA polimerase, sendo em seguida desnaturadas para formar duas fitas de DNA fita simples (ssDNA). Tal processo foi repetido em cada molde por ciclos de desnaturação e amplificação isotérmica para criar milhões de agrupamentos clonais. Cada grupo de pontes de dsDNA foi desnaturado e a fita reversa foi removida e, em seguida, os primers de sequenciamento foram hibridizados às suas sequências complementares nos adapatadores.

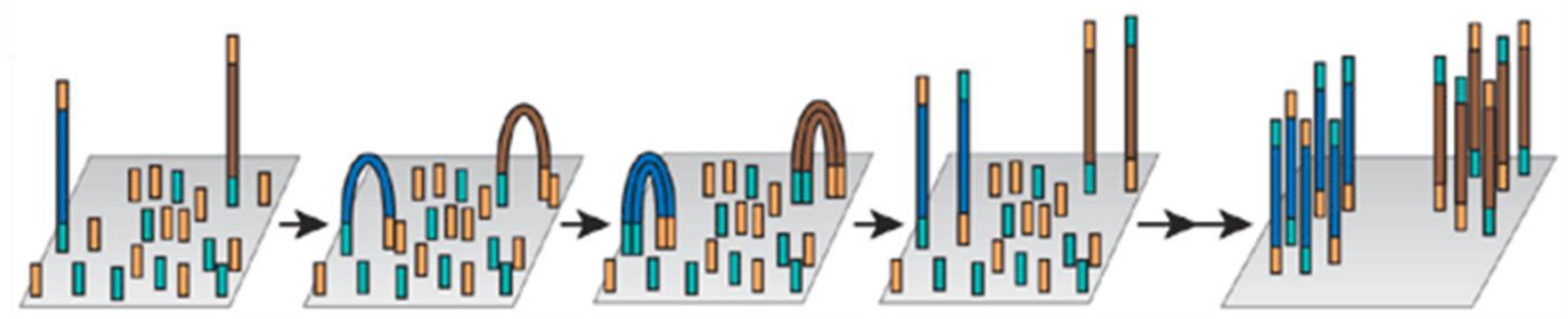

Figura 4 - Representação da amplificação em ponte. As fitas de cDNA se hibridizam à camada de oligonucleotídeos presente na superfície da célula de fluxo, curvando-se em formato de ponte. As fitas são copiadas por DNA polimerase, formando pontes de dupla fita que são subsequentemente desnaturadas. A repetição dos ciclos de amplificação e desnaturação geram milhares de agrupamentos clonais (figura modificada de Shendure e Ji, 2008).

\subsubsection{Sequenciamento}

O sequenciamento por síntese dos grupos clonais foi realizado em aparelho Genome Analyzer Ilx (Illumina, Inc.), utilizando o TruSeq SBS kit v5 (Illumina Inc.). Os moldes de DNA foram copiados base a base utilizando nucleotídeos associados a um terminador reversível marcado fluorescentemente. Após cada passo de síntese, os agrupamentos foram excitados por um laser, levando à emissão de fluorescência da última base adicionada, e então o terminador foi removido, permitindo a incorporação do próximo nucleotídeo. Os sinais fluorescentes de cada ciclo de síntese foram, então, capturados por uma câmera do próprio aparelho. 


\subsection{Análise dos dados}

\subsubsection{Chamada de bases}

Após o sequenciamento, as imagens obtidas a partir da captura da florescência dos agrupamentos clonais foram analisadas, gerando a intensidade dos grupos e uma estimativa do ruído em cada leitura. Essa análise gerou o arquivo de entrada para a chamada de bases, que utiliza justamente as intensidades e a estimativa do ruído dos agrupamentos para gerar uma sequência de bases lida de cada grupo clonal, um nível de confiança para cada base e se as reads passaram pela filtragem. A chamada de bases gerou arquivos ".bcl" (chamada de base binária - do inglês binary base call), que foram convertidos em arquivos FASTQ, compatíveis com os algoritmos de alinhamento, utilizando o programa CASAVA 1.8 (Illumina, Inc.). Para análise da qualidade dos dados do sequenciamento, foi utilizado o programa FastQC (Babraham Institute, 2014).

\subsubsection{Alinhamento das sequências}

As sequências foram alinhadas contra o genoma de referência GRCh37.p13 (GENCODE) com o algoritmo Tophat v. 2.0.3 (Trapnell et al. 2009). Essa é uma boa ferramenta para alinhamento de reads para identificação de sítios de splicing entre éxons. O arquivo de saída desta análise é em formato BAM (forma binária, indexada e comprimida do SAM)

\subsubsection{Análise da expressão gênica}

Em seguida, utilizou-se o HTSeq (Anders; Pyl; Huber, 2014) da linguagem de programação Python, o qual permite o desenvolvimento rápido de roteiros para o processamento e análise de dados de sequenciamento de larga escala. Desse pacote, utilizou-se a ferramenta HTSeq-count para contar, para cada gene, quantas reads alinhadas se sobrepuseram a éxons (aquelas que se alinharam em múltiplas posições ou que se sobrepuseram a mais de um gene foram desconsideradas).

Essas contagens foram, em seguida, utilizadas para análise de expressão diferencial com o pacote DESeq2 (Love; Huber; Anders, 2014) do Bioconductor, que permite uma 
análise mais quantitativa de dados de RNA-seq pelo melhoramento das estimativas de dispersão e fold change.

\subsubsection{Caracterização funcional dos IncRNAs}

Para a caracterização funcional dos IncRNAs diferencialmente expressos nas amostras tumorais, foi realizada a busca da função dessas moléculas na literatura e, adicionalmente, foram utilizadas as ferramentas IncRNA2function (http://mlg.hit.edu.cn/Incrna2function), IncRNAtor (http://Incrnator.ewha.ac.kr/) e LNCipedia (http://www.Incipedia.org/).

\subsection{Validação de expressão de IncRNA por PCR semi-quantitativa}

Foi selecionado o IncRNA LINC00472 para validação por PCR semi-quantitativa. Esta técnica é uma técnica simples e rápida, e que permite a avaliação qualitativa da expressão gênica pela comparação entre as amostras.

Primeiramente, foi sintetizado cDNA de seis pares tumorais (três mama-linfonodo e três mama-cérebro), utilizando primers randômicos e a enzima Multiscribe (Thermo Fischer Sientific, Waltham, MA, USA), a partir de 500 ng de RNA de cada amostra. Em seguida, $20 \mu \mathrm{l}$ dos cDNAs foram serialmente diluídos em água água estéril, gerando sete diluições $(1: 4,1: 8$, 1:16, 1:32, 1:64 e 1:128). De cada diluição foi utilizado $2 \mu \mathrm{l}$ para avaliação da expressão do LINC00472, utilizando os primers: F- 5'- GGGCTGCGGGAACATTAAAA-3' e R- 5'GTCCACATCCTTCTCCTATC-3'. Como endógeno, foi utilizado o gene da $\beta$-tubulina (TUBB) (primers: F- 5'-TCAACACTTTCTTCAGTGAAACG-3' e R- 5'- AGTGCCAGTGCGAACTTCATC -3').

Para verificação da amplificação da sequência do IncRNA e do endógeno, foi utilizado 5 $\mu l$ do produto de PCR para eletroforese em gel de agarose $1 \%$ e a visualização foi feita em transluminador UV (UVP, USA). 


\section{RESULTADOS}

\subsection{Dados clínicos das amostras tumorais}

Todas as amostras tumorais obtidas foram avaliadas pelo serviço de patologia do HCFMRP e os dados clínicos e histopatológicos dos tumores de mama estão contidos na tabela 1.

Tabela 1 - Características histológicas e clínico-patológicas dos tumores de mama.

\begin{tabular}{lcc}
\hline \multicolumn{1}{c}{ Tumor de mama } & $\mathrm{n}(20)$ & $\%$ \\
\hline $\begin{array}{l}\text { Idade da paciente } \\
\quad 50 \text { anos }\end{array}$ & 8 & 40,00 \\
$\quad>50$ anos & 12 & 60,00 \\
Tipo de Câncer & 16 & 80,00 \\
$\quad$ CDI & 4 & 20,00 \\
$\quad$ Outros & & \\
Receptor de Estrogênio & 13 & 65,00 \\
$\quad$ Positivo & 7 & 35,00 \\
$\quad$ Negativo & & \\
Receptor de Progesterona & 9 & 45,00 \\
$\quad$ Positivo & 11 & 55,00 \\
$\quad$ Negativo & & \\
Receptor do Fator 2 Epidermal Humano (Her2/neu) & 65,00 \\
$\quad$ Positivo & 13 & 35,00 \\
Negativo & 7 & 5,00 \\
NI & 1 & \\
Classificação Molecular & & 25,00 \\
Luminal A e B & 5 & 65,00 \\
HER2 & 13 & 5,00 \\
Basal - TN & 1 & 5,00 \\
NI & 1 & \\
\hline
\end{tabular}

CDI, Carcinoma Ductal Invasivo; TN, Triplo Negativo, Ausência do receptor de estrogênio, progesterona e Fator 2 Epidermal Humano; NI, Não Informado.

\subsection{Qualidade dos RNAs para sequenciamento}

Todas as amostras tiveram seu RNA extraído e avaliado quanto à sua qualidade (Tabela 2). A partir desse resultado, foram selecionados os pares com RNAs mais íntegros possíveis para posterior sequenciamento. 
Tabela 2 - Avaliação da integridade dos RNAs extraídos das amostras tumorais.

\begin{tabular}{ccccc}
\hline $\begin{array}{c}\text { Amostra tumor } \\
\text { primário }\end{array}$ & RIN & $\begin{array}{c}\text { Amostra metastática } \\
\text { pareada }\end{array}$ & RIN & $\begin{array}{c}\text { Órgão da } \\
\text { metástase }\end{array}$ \\
\hline PM1 & - & MC1 & 6.60 & \\
PM2 & 7.70 & MC2 & 9.00 & Cérebro \\
PM3 & 8.90 & MC3 & 5.50 & \\
PM4 & - & MC4 & 7.80 & \\
PM5 & 6.00 & MC5 & 8.30 & \\
PM6 & 7.70 & ML1 & 4.20 & \\
PM7 & - & ML2 & 3.00 & \\
PM8 & 7.50 & ML3 & 3.70 & \\
PM9 & 5.90 & ML4 & 2.70 & \\
PM10 & 5.40 & ML5 & 6.70 & \\
PM11 & 2.60 & ML6 & 5.90 & \\
PM12 & 2.60 & ML7 & 3.100 & \\
PM13 & 3.00 & ML8 & 7.20 & \\
PM14 & 6.00 & ML9 & 7.50 & \\
PM15 & 3.100 & ML10 & 3.90 & \\
PM16 & 4.50 & ML11 & 7.00 & \\
PM17 & 7.80 & ML12 & 6.30 & \\
PM18 & 7.30 & ML13 & 7.100 & \\
PM19 & 5.30 & ML14 & 7.40 & \\
PM20 & 6.20 & ML15 & 6.90 & \\
\hline
\end{tabular}

RIN, Número de Integridade do RNA; PM, tumor primário de mama; MC, tumor metastático em cérebro; ML, tumor metastático em linfonodo.

A partir da análise dos RINs, foram selecionados os pares PM2 - MC2 e PM5 - MC5, correspondentes aos tumores de mama que metastizaram para o cérebro, sendo eles dos subtipos luminal e Her2, respectivamente. Os pares PM17 - ML12, PM18 - ML13 e PM20 ML15 correspondem aos tumores primários de mama que metastizaram para linfonodo e os subtipos moleculares dos carcinomas primários são, respectivamente: triplo negativo, luminal e Her2.

\subsection{Análise do RNA-seq}

\subsubsection{Qualidade do sequenciamento}

A qualidade do sequenciamento foi acessada a partir do escore de qualidade Phred (escore Q), que reflete a precisão da chamada de bases, ou seja, indica a probabilidade de 
determinada base ter sido incorretamente chamada pelo sequenciador. Em todas as amostras sequenciadas, o escore $Q$ estava acima de 30 , o que indica que a probabilidade da chamada de base estar correta é de $99,9 \%$.

\subsubsection{Mapeamento}

O sequenciamento das amostras tumorais gerou mais de 31.000 reads por amostra, sendo mais de $84 \%$ delas mapeadas contra o genoma de referência (Tabela 3).

Tabela 3 - Total de reads geradas pelo RNA-seq das amostras tumorais primárias e metastáticas e quantidade de reads mapeadas contra o genoma de referência GRCh37.p13.

\begin{tabular}{cccc}
\hline Amostra & Total de reads & Reads mapeadas & Reads mapeadas (\%) \\
\hline MC2 & 61.160 .613 & 59.377 .307 & 97,1 \\
MC5 & 36.335 .915 & 34.966 .789 & 96,2 \\
ML12 & 33.653 .331 & 31.332 .027 & 93,1 \\
ML13 & 43.908 .604 & 41.676 .353 & 94,9 \\
ML15 & 39.621 .444 & 37.667 .088 & 95,1 \\
PM2 & 66.716 .734 & 64.333 .825 & 96,4 \\
PM5 & 40.016 .389 & 33.794 .185 & 84,5 \\
PM17 & 32.902 .987 & 31.020 .038 & 94,3 \\
PM18 & 41.227 .383 & 39.488 .143 & 95,8 \\
PM20 & 38.769 .275 & 35.125 .650 & 90,6 \\
\hline
\end{tabular}

Nos tumores primários de mama pareados com suas respectivas metástases em linfonodo, aproximadamente $55 \%$ das reads mapearam em regiões de RNAs não codificadores de proteína e cerca de 35\% correspondeu a RNAs codificadores de proteína (Figura 5). Os tumores primários de mama e seus tumores metastáticos em cérebro correspondentes apresentaram proporções similares de RNAs codificadores e não codificadores de proteína, tanto entre si quanto em relação ao primeiro grupo. Além disso, a quantidade de transcritos que pertencem a um lócus de pseudogene ou a outras classes menores de RNAs foi bem similar entre os três tipos de tumor. 

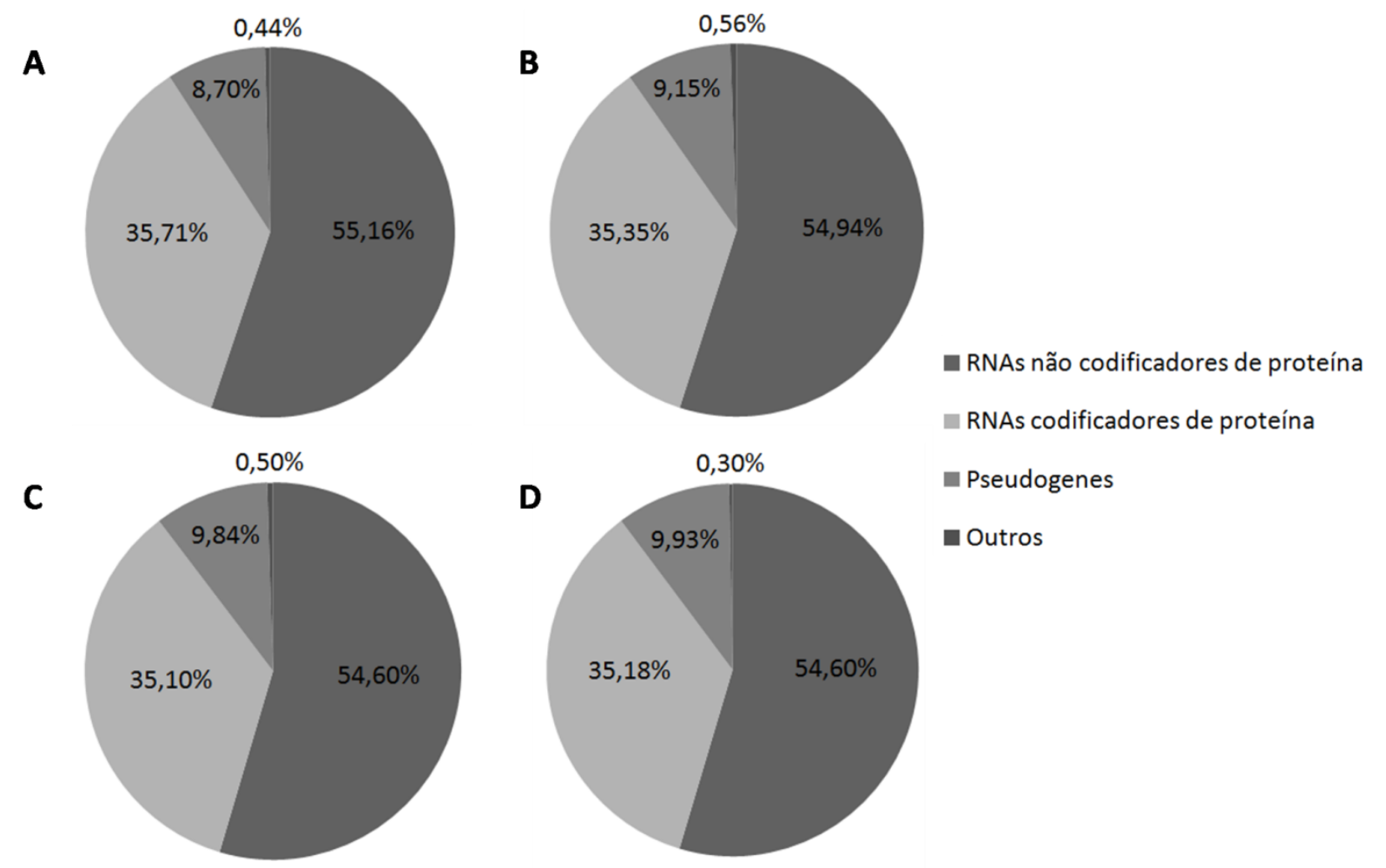

Figura 5 - Classes de RNAs às quais pertencem as reads mapeadas resultantes do RNA-seq das amostras tumorais. Tumores primários de mama (A) pareados com metástases em linfonodos (B) e tumores primários de mama (C) pareados com metástases em cérebro (D).

\subsubsection{Análise dos IncRNAs expressos nas amostras tumorais}

A partir dos dados do mapeamento, foi observado que os RNAs não codificadores foram os transcritos mais representados dentre todos os expressos e, dentre os ncRNAs, o RNAs longos não codificadores formaram a classe mais abundante. Estes, por sua vez, foram divididos em seis categorias, de acordo com a classificação do GENCODE, sendo elas: antisenso, senso sobreposto, senso intrônico, ncRNA sobreposto a 3', lincRNA e íntron retido. Analisando as classes de IncRNAs, observou-se que elas apresentaram abundâncias de transcritos bem similares entre as amostras tumorais (Figura 6). 


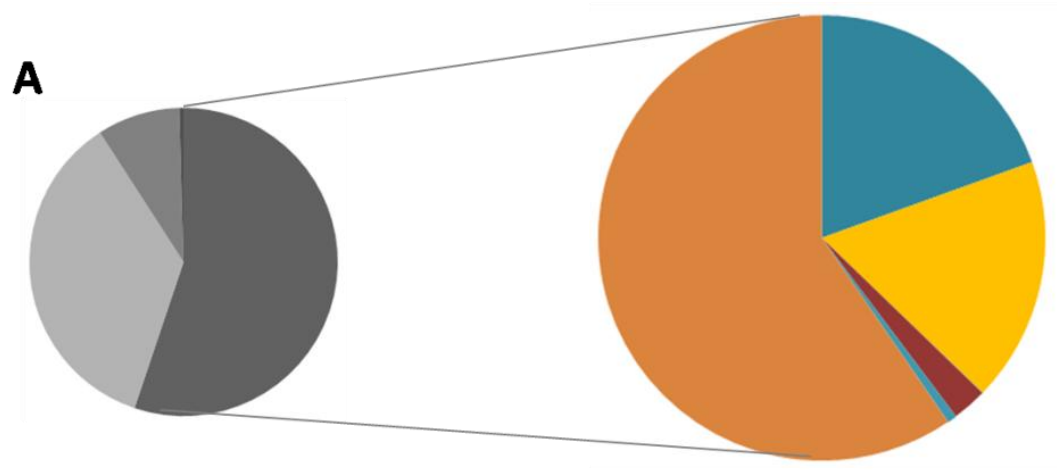

antisenso $(19,50 \%)$

- lincRNA $(17,70 \%)$

ncRNA sobreposto a 3' $(0,05 \%)$

- Senso intrônico (2,51\%)

- Senso sobreposto $(0,70 \%)$

— Íntron retido $(59,60 \%)$

B

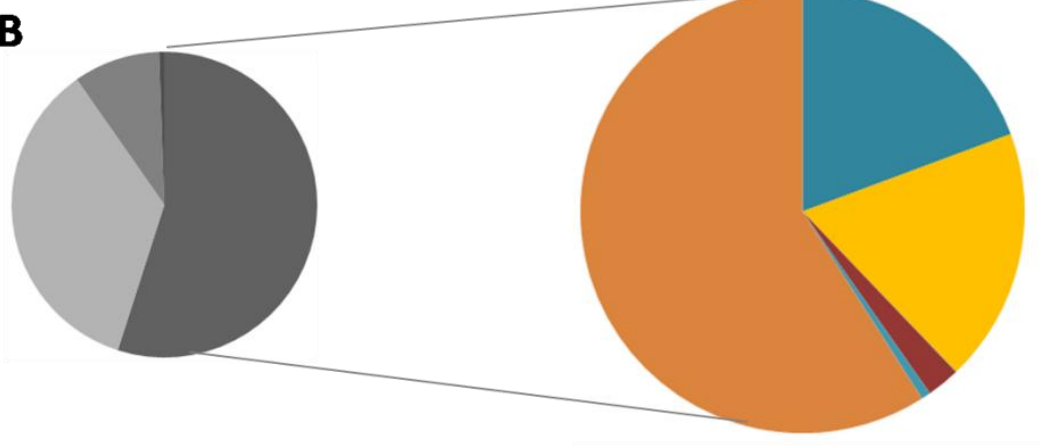

c
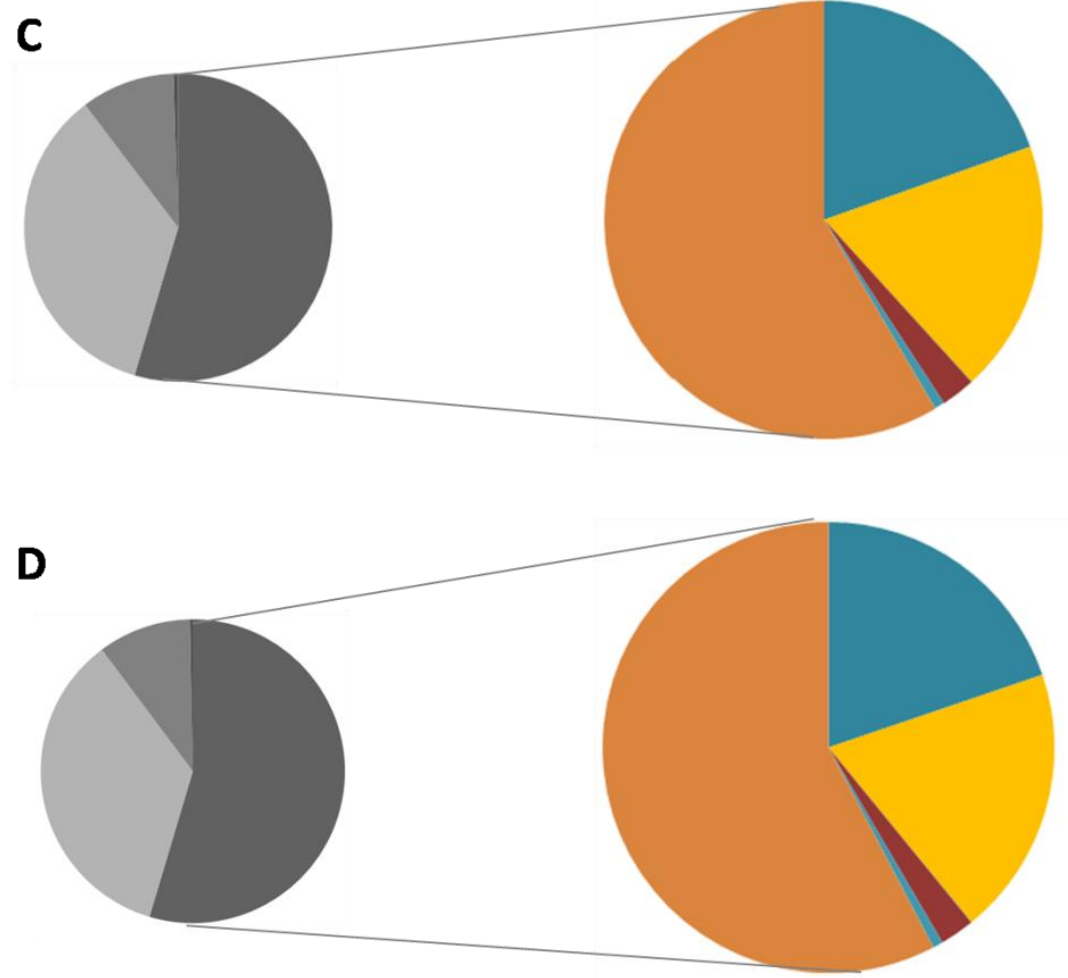

- Antisenso (19,32\%)

- lincRNA $(18,51 \%)$

ncRNA sobreposto a $3^{\prime}(0,05 \%)$

• Senso intrônico $(2,41 \%)$

- Senso sobreposto $(0,70 \%)$

- Íntron retido (59,03\%)

- lincRNA (18,65\%)

ncRNA sobreposto a 3' (0,04\%)

— Senso intrônico (2,52\%)

n Senso sobreposto $(0,74 \%)$

— Íntron retido (58,50\%)

Antisenso $(19,80 \%)$

- lincRNA (19,30\%)

ncRNA sobreposto a 3' (0,05\%)

— Senso intrônico (2,50\%)

n Senso sobreposto (0,71\%)

- Íntron retido (57,70\%)

Figura 6 - Classes de IncRNAs encontradas nas amostras tumorais após o mapeamento. Tumores primários de mama (A) e seus correspondentes metastáticos em linfonodo (B); tumores primários de mama (C) e seus correspondentes metastáticos em cérebro (D). 
Em todos os casos, os íntrons retidos foram os transcritos predominantes, representando quase $60 \%$ de todos os IncRNAs expressos nas amostras primárias e metastáticas. Além desses, os transcritos antisenso e intergênicos foram bem representados, com média de $19,5 \%$ e $18,5 \%$ dos IncRNAs, respectivamente.

A partir da observação de que as amostras tumorais são bastante homogêneas quanto à quantidade de transcritos não codificadores longos, foram construídos diagramas de Venn para verificar se esses IncRNAs eram os mesmos expressos em todas as amostras primárias e nas amostras metastáticas (Figura 7). Observa-se que grande parte dos transcritos, tanto nos pares de mama-linfonodo (Figura 7A) quanto nos pares mama-cérebo (Figura 7B), são compartilhados entre os tumores primários e metastáticos (aproximadamente 16.700 e 17.850, respectivamente), o que mostra mais uma vez que esses dois tipos tumorais são muito semelhantes entre si e o que os diferencia minimamente é uma parcela pequena de transcritos.

A

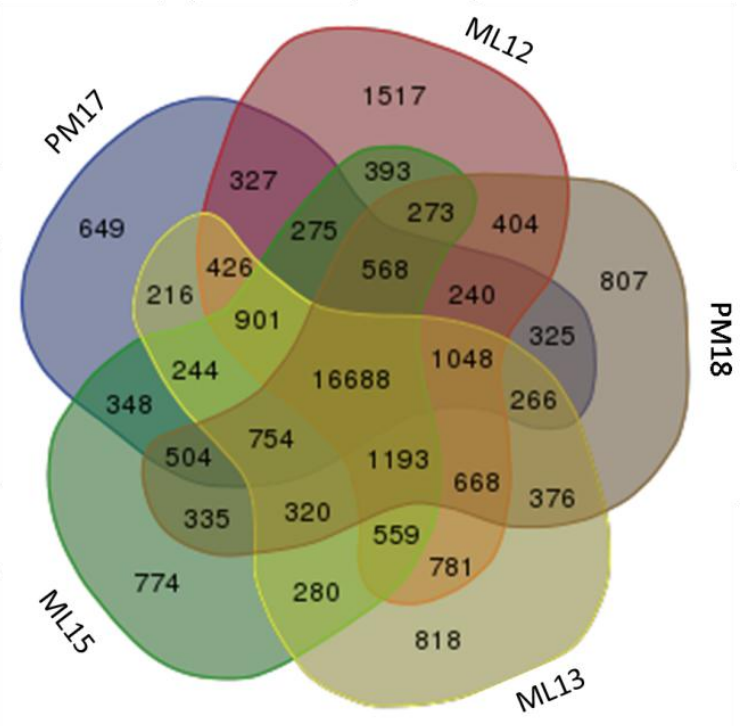

B

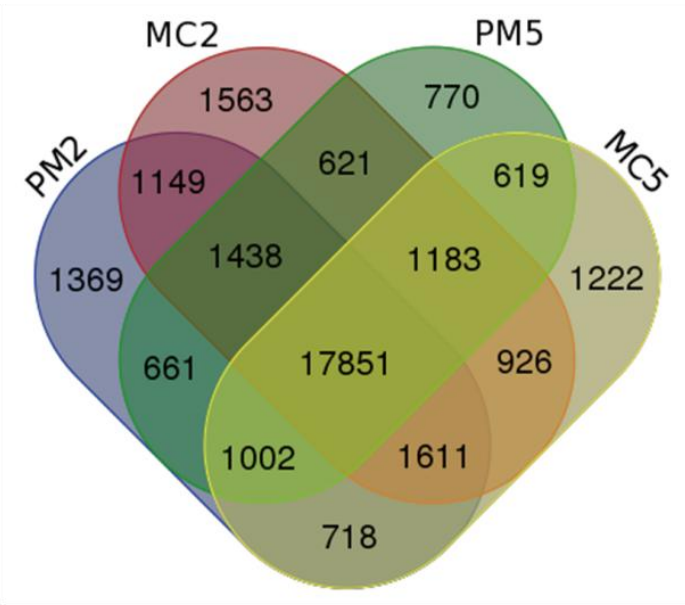

Figura 7 - LncRNAs comuns e exclusivos entre os pares de (A) tumores primários de mama e respectivas metástases em linfonodo e (B) tumor primário de mama e respectivas metástases em cérebro.

Também foram construídos diagramas para ilustrar a quantidade de IncRNAs comuns e exclusivos entre os tumores primários e entre os metastáticos (Figura 8). Nas amostras de tumor primário de mama, mais de 16.700 transcritos são comuns entre todos os tumores, 
mesmo que os cinco sejam de subtipos diferentes (PM2 e PM18 do subtipo luminal, PM5 e PM20 do Her2 e PM17 do subtipo triplo negativo) (Figura 8A). A amostra PM2 possui o maior número de transcritos exclusivos, enquanto que a PM5 é a que possui a menor quantidade desses transcritos.

Os tumores metastáticos apresentaram um número similar aos tumores primários de transcritos comuns expressos em todos os cinco (Figura 8B). As amostras MC2 e ML12 são as que possuem as maiores quantidades de transcritos exclusivos, com 1.139 e 1.198 respectivamente. O número de IncRNAs comuns aos tumores metastáticos em linfonodo axilar é praticamente o dobro (543) do número de transcritos não codificadores longos comuns aos tumores primários de mama (269) que originaram essas metástases. No caso dos tumores metastáticos em cérebro, o número de IncRNAs compartilhados entre eles é aproximadamente $58 \%$ maior (585) que o número de transcritos comuns entre os tumores de mama que os originaram (369).

A

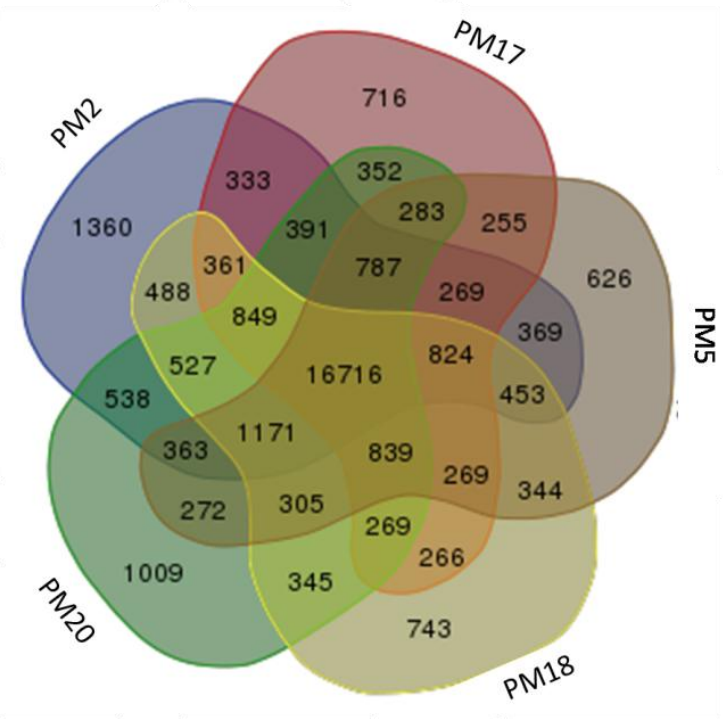

B

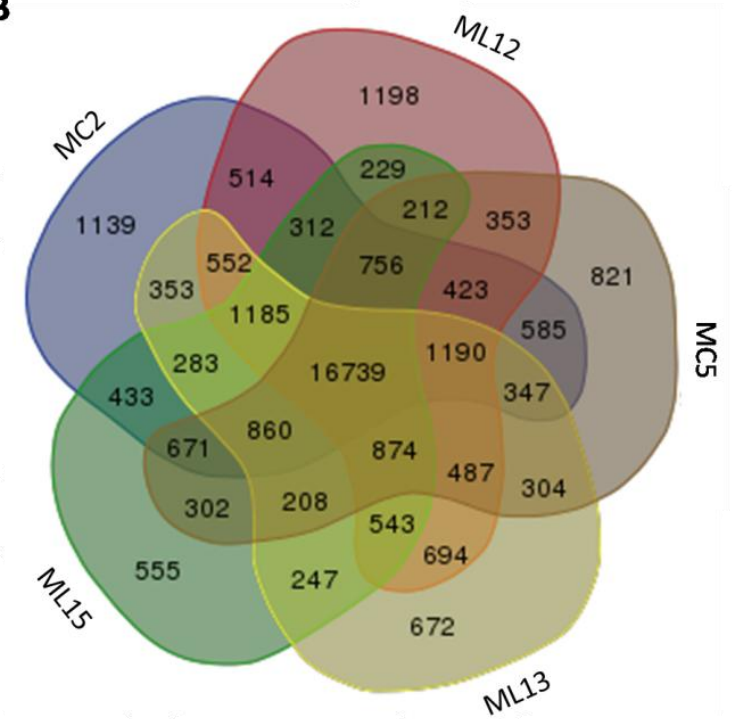

Figura 8 - LncRNAs comuns e exclusivos entre as amostras de tumor primário de mama (A) e de tumor metastático de mama (B). Cores iguais correspondem a um par tumor primário-tumor metastático.

Esses resultados apontam que as amostras primárias e suas respectivas metástases, assim como as amostras primárias e metastáticas, independente de pareamento, são muito 
semelhantes. Tal semelhança não se restringe à representatividade de cada classe de IncRNA, mas também se refere à quantidade de transcritos compartilhados entre os tumores.

Adicionalmente, foi realizada a busca pela função dos IncRNAs expressos nas amostras tumorais em bases de dados (IncRNAdb, LNCipedia, GeneCards, PubMed), porém verificouse que a grande maioria deles ainda não possui nenhuma descrição funcional. Apesar disso, puderam ser encontrados alguns transcritos bem expressos nas amostras tumorais que já estão descritos na literatura como envolvidos no câncer de mama, alguns deles estão contidos na figura 9. 

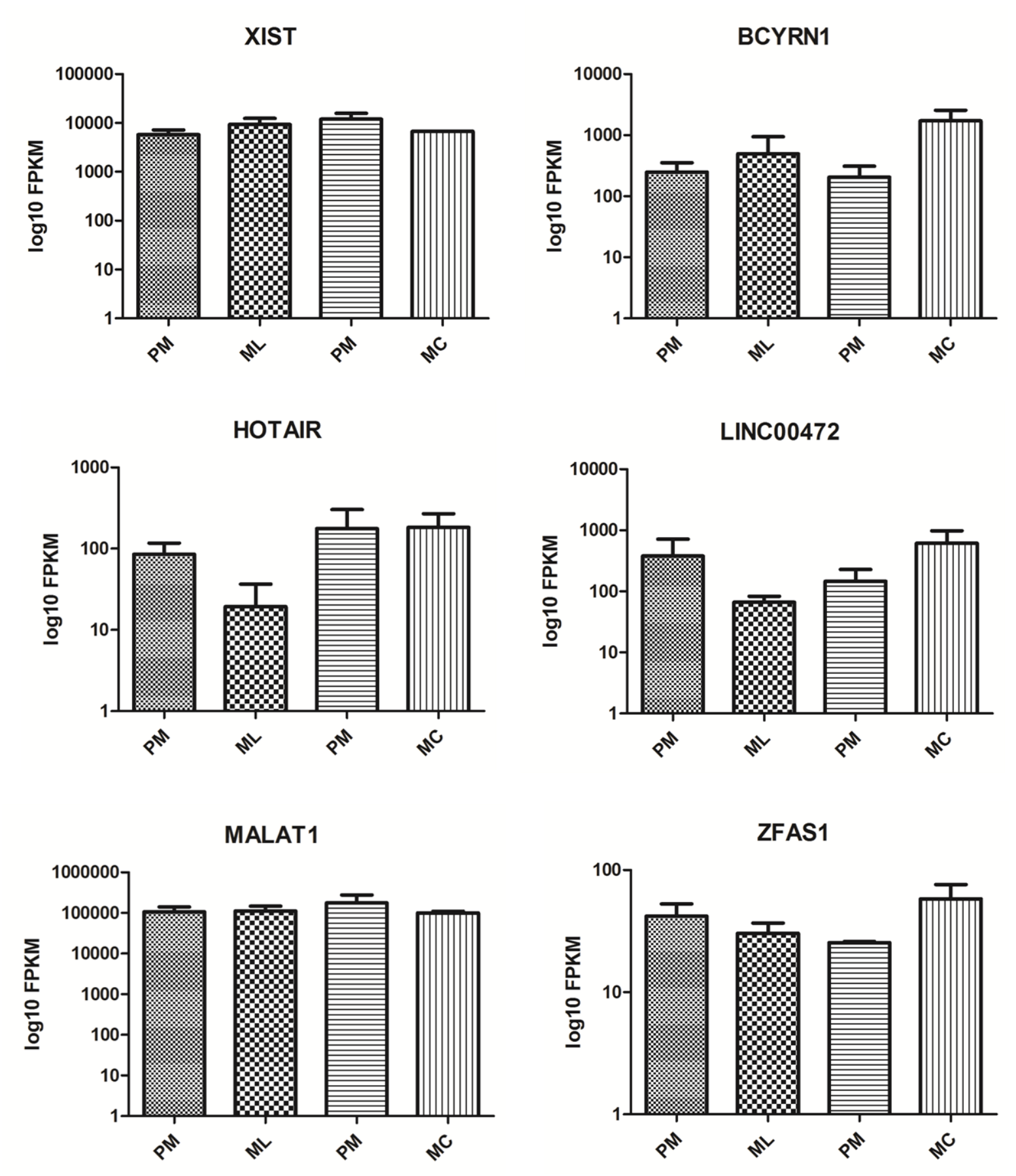

Figura 9 - Expressão de IncRNAs já conhecidos em câncer de mama nas amostras tumorais. À esquerda das colunas de tumores metastáticos (ML e $\mathrm{MC}$ ) encontram-se as colunas dos seus tumores primários correspondentes. 


\subsubsection{Análise da expressão diferencial dos IncRNAs}

Após a verificação de quais eram os IncRNAs que estavam sendo expressos nas amostras tumorais e de como eles estavam distribuídos em cada uma, foi realizada a análise dos transcritos que se encontravam diferencialmente expressos entre as amostras de tumor primário e as suas respectivas metástases, utilizando o pacote DESeq2 do Bioconductor.

Nos tumores primários de mama e nas suas metástases correspondentes em linfonodo, foi encontrado um número similar de IncRNAs mais expressos - 59 e 54, respectivamente (Anexos $\mathrm{A}$ e $\mathrm{C}$ ). Metade dos transcritos mais expressos nos tumores primários corresponde a íntrons retidos, 24\% são transcritos antisenso, 20,4\% são lincRNAs e 5,6\% são transcritos senso intrônicos, sendo os transcritos RP11-1002K11.1-001 (lincRNA), COL1A2-002 e STEAP2-008 (íntrons retidos) os mais expressos nessas amostras. Nas metástases em linfonodo, a classe de IncRNA mais abundante foi a dos lincRNAs, com 37,3\%, seguida dos íntrons retidos, com aproximadamente 34\% dos transcritos, dos IncRNAs antisenso com 25,4\% e, por fim, dos transcritos sobrepostos a 3' e dos senso intrônicos, que juntos englobam 3,4\% dos IncRNAs mais expressos. Os transcritos CD22-011, RP11297B17.3-001 e LINC00861-001 foram os mais diferencialmente expressos em linfonodos (Figura 10A), quando comparados com suas amostras de mama pareadas, sendo eles das classes íntron retido, antisenso e lincRNA, respectivamente.

O grupo dos pares de tumores de mama pareados com metástases em cérebro apresentou um número menor de IncRNAs diferencialmente expressos, quando comparado ao grupo mama-linfonodo: os tumores primários possuem 18 transcritos altamente expressos e suas respectivas metástases têm 14 (Anexos B e D). Os íntrons retidos representam pouco mais da metade $(55,6 \%)$ dos IncRNAs mais expressos nas amostras de tumor primário, os transcritos antisenso correspondem a $27,8 \%$ e os lincRNAs a $16,6 \%$ dos RNAs mais expressos. Dentre eles, o COL6A3-009, o TBX5-AS1-001 e o RP11-40109.4-001 se sobressaem como os mais diferencialmente expressos nas amostras de mama, sendo o primeiro um íntron retido e os dois últimos transcritos antisenso. 
A

Metástases linfonodo Vs Primários mama

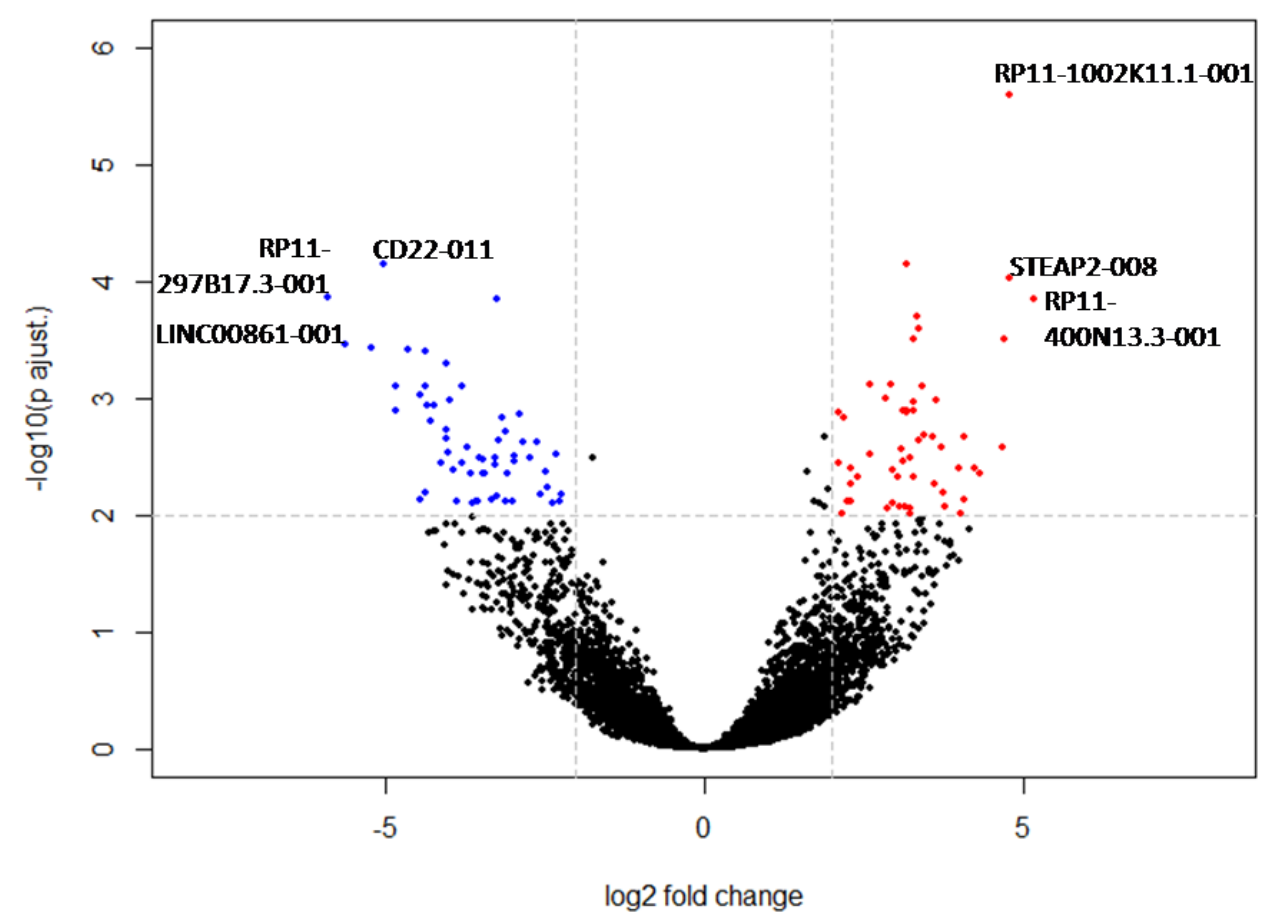

B

Metástases cérebro Vs Primários mama

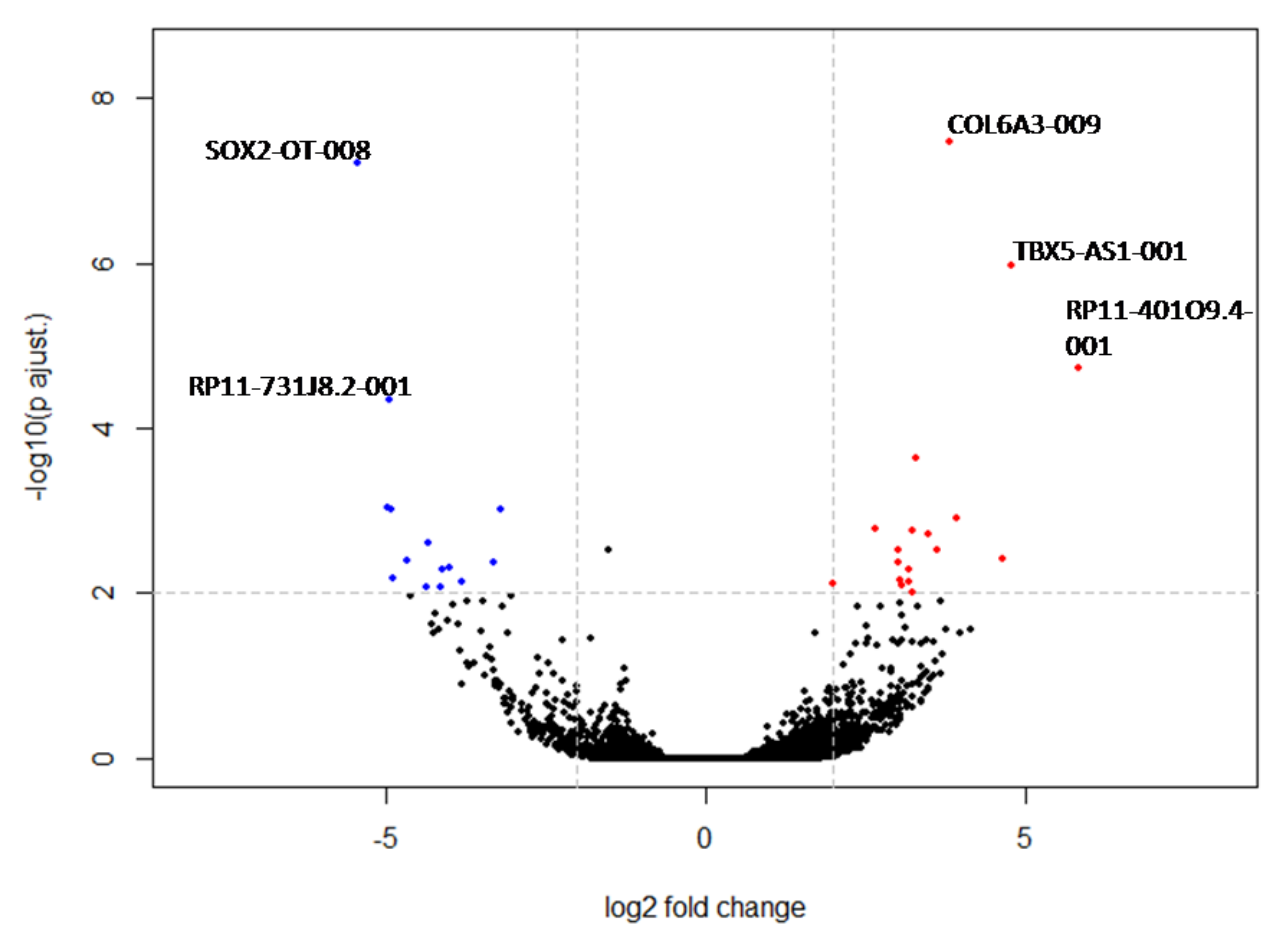

Figura 10 - Expressão diferencial de IncRNAs entre as amostras de tumor de mama primário e seus correspondentes metastáticos. Em azul, IncRNAs mais expressos nas metástases; em vermelho, IncRNAs mais expressos nos tumores primários. 
Assim como nas amostras metastáticas em linfonodo, nas amostras de cérebro os lincRNAs são os mais numerosos (43\%), já o restante dos transcritos se dividem em $28,6 \%$ de íntrons retidos, $21,4 \%$ de transcritos senso sobrepostos e $7 \%$ de ncRNAs sobrepostos a 3'. Os IncRNAs SOX2-OT-008 e RP11-731J8.2-001 são os mais expressos nessas amostras metastáticas (Figura 10B) e ambos pertencem à classe dos transcritos senso sobrepostos.

É interessante apontar que os tumores primários de mama, independente da via metastática (hematógena ou linfática) que seguiram posteriormente ou dos seus subtipos moleculares, possuem doze transcritos diferencialmente expressos em comum, como o RP11-1002K11.1-001, o TBX5-AS1-002 e o RP11-40109. Os tumores metastáticos em linfonodo e em cérebro, contrariamente, não possuem nenhum IncRNA diferencialmente expresso comum a ambos.

Adicionalmente, foi realizada a análise de interação entre proteínas e os três IncRNAs mais expressos de cada grupo amostral, utilizando a ferramenta IncRNAtor. Foi observado que a maioria dos IncRNAs interage com proteínas envolvidas com o processamento de mRNA e com splicing alternativo (Anexo F). Também foram identificadas interações com proteínas envolvidas em vias de sinalização importantes no contexto do câncer (vias de sinalização de EGFR, de TGF- $\beta$ e Notch).

Em seguida, os IncRNAs diferencialmente expressos foram utilizados para análise de agrupamento hierárquico não supervisionado dos dados de expressão (Figura 11). As amostras de mama formaram um grupo, as metástases em cérebro formaram outro e as amostras metastáticas em linfonodo consistiram de duas semelhantes entre si e uma que se assemelhou aos tumores primários de mama (ML15). Percebe-se que há três assinaturas de IncRNAs - dos tumores primários, das metástases em linfonodo e das metástases em cérebro - das quais a de linfonodo se sobressai pela homogeneidade de expressão entre ambas as amostras.

As amostras de metástase em cérebro estão mais próximas das amostras de tumor primário do que as amostras metastáticas em linfonodo, com excessão da ML15. No conjunto de tumores primários, curiosamente, as amostras mais semelhantes entre si não pertencem ao mesmo subtipo de câncer de mama: PM17 e PM20 são dos subtipos triplo 
negativo e Her2, respectivamente; e PM5 e PM18 são provenientes de câncer de mama Her2 e luminal, nesta ordem.

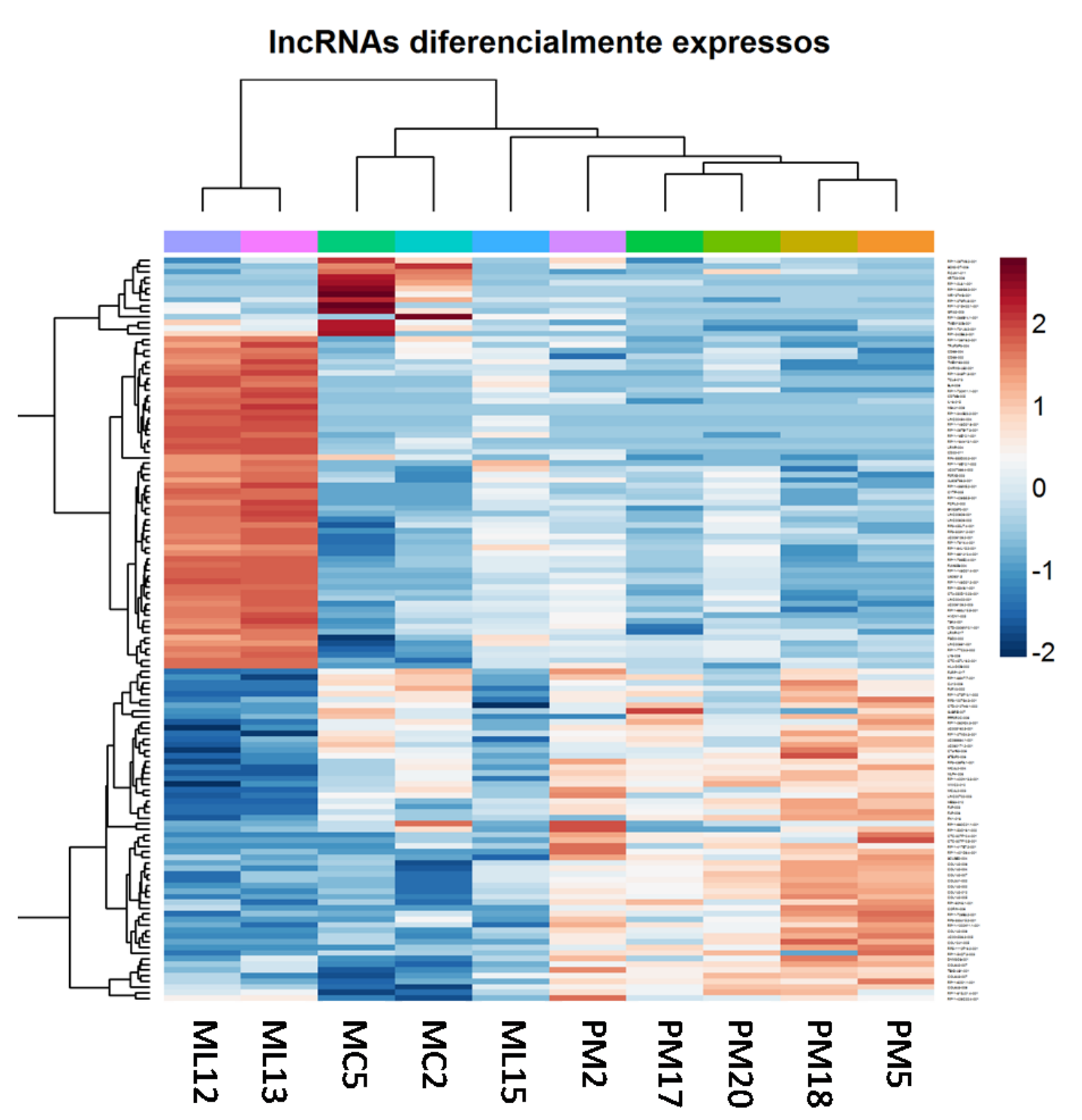

Figura 11 - Agrupamento hierárquico dos IncRNAs com expressão diferencial entre as amostras tumorais.

\subsubsection{Validação de IncRNA}

Devido aos seus papéis já descritos na literatura e por ser um transcrito recentemente descrito, foi selecionado o IncRNA LINC00472 para validação por PCR semi-quantitativa em seis pares tumorais. O resultado do RNA-Seq demonstrou que, analisando para a par, a 
expressão absoluta do LINC00472 variou bastante nas amostras tumorais, não seguindo um padrão definido (Figura 12A). A PCR semi-quantitativa revelou a mesma falta de padrão nas amostras (Figura 12B), sendo o IncRNA bastante expresso no par tumoral PM1-ML1 e em duas metástases em cérebro (MC4 e MC5), apresentando expressão mesmo na diluição 1:32. Em contrapartida, outros pares tumorais, como PM2-ML2 e PM6-MC6 não apresentaram expressão de LINC00472.

A LINC00472

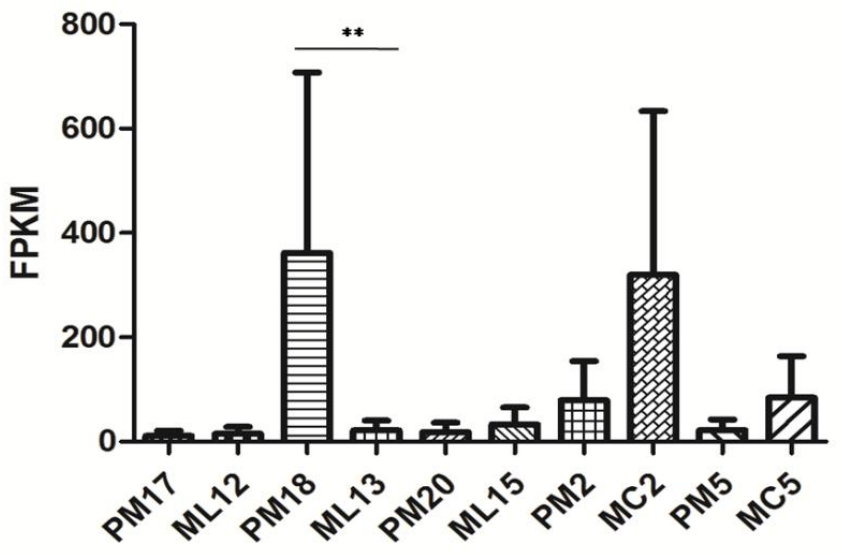

B

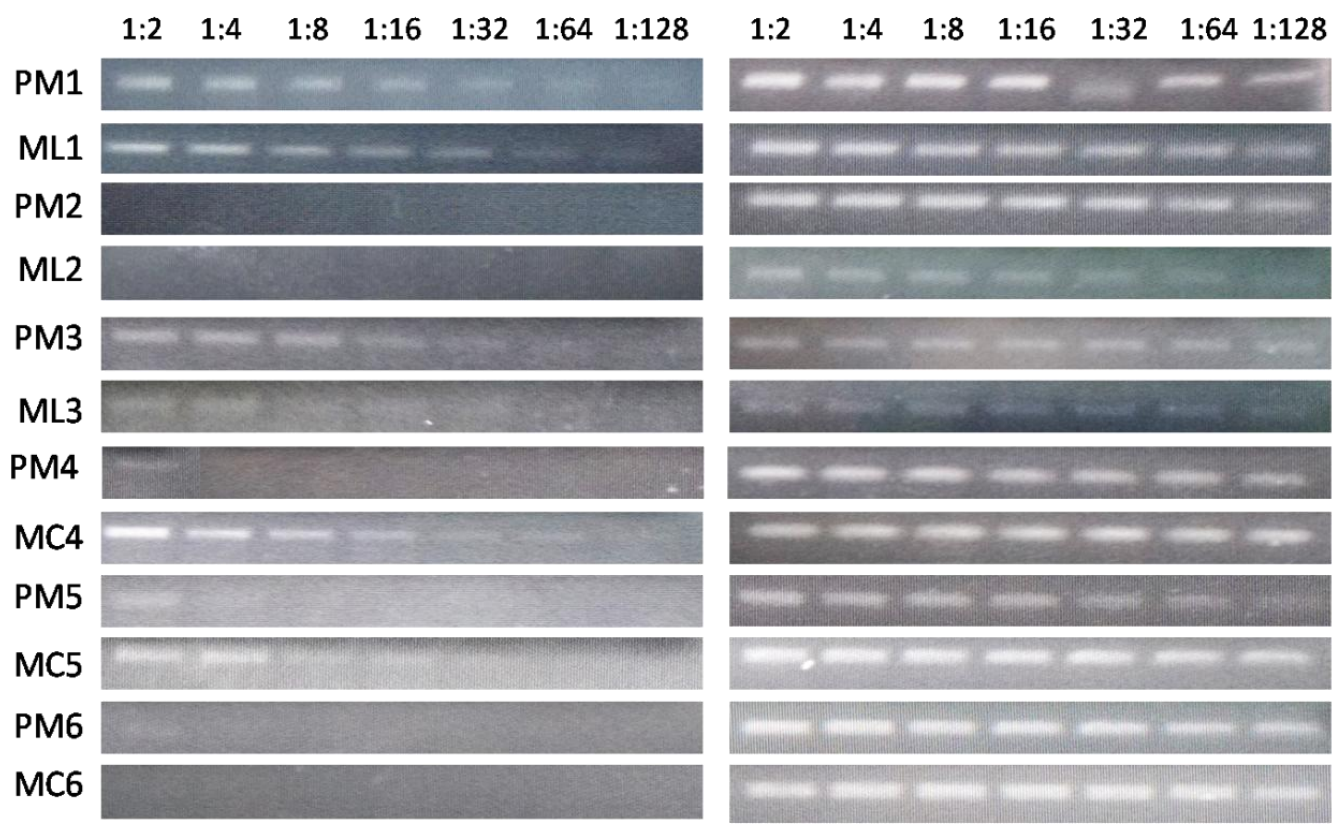

Figura 12 - PCR semi-quantitativa do IncRNA LINC00472. Assim como os valores de expressão obtidos do RNA-Seq (A), a PCR demonstrou variação na expressão desse transcrito nas amostras tumorais ( $B$ ). TUBB, endógeno ( $\beta$-tubulina); $P M$, tumor primário de mama; $M L$, metástase em linfonodo; $\mathrm{MC}$, metástase em cérebro. $\mathrm{Em} \mathrm{B}$, números iguais correspondem a um par tumor primário-metástase. 


\section{DISCUSSÃO}

O câncer de mama é altamente relevante epidemiologicamente, uma vez que sua incidência na população é alta e acomete principalmente as mulheres. Muitos fatores de risco estão associados ao seu desenvolvimento, incluindo fatores reprodutivos, como idade na primeira gravidez e amamentação, fatores hormonais, como o uso de contraceptivos, e fatores genéticos (Ban; Godellas, 2014). Apesar de já haver diversos biomarcadores bem estabelecidos para o prognóstico e tratamento do câncer de mama, como mutações nos genes BRCA1/2 e p53 e outros tantos genes de alta ou moderada penetrância familial (Sana; Malik, 2015; Scalia-Wilbur et al., 2016), eles ainda não são suficientes para explicar por completo as razões e os mecanismos por trás da metástase.

O desenvolvimento de tecnologias de sequenciamento profundo trouxe a possibilidade de sequenciar transcritos pouco expressos e de quantificar a sua abundância na população (Ding et al., 2014). O sequenciamento de RNA (RNA-Seq) é um método de sequenciamento de nova geração (NGS) que permite uma visão mais detalhada e quantitativa da expressão gênica, do splicing alternativo e da expressão alelo-específica (Kukurba; Montgomery, 2015). O método do RNA-Seq se baseia na determinação das sequências de pequenos fragmentos de cDNA, possibilitando o sequenciamento de virtualmente todo o transcriptoma e a descoberta de novos loci e novos transcritos (Ilott e Ponting, 2013). Tais características tornam o RNA-Seq uma técnica apropriada para o estudo dos IncRNAs, uma vez que os mesmos possuem, de uma forma geral, níveis de expressão mais baixos que os mRNAs (Kornienko et al., 2016 apud Cabili et al., 2011, p. 1923).

Os IncRNAs, dentre todas as moléculas de RNAs não codificadores, são ainda a classe menos conhecida, o que se reflete na grande quantidade de transcritos anotados, porém sem função descrita (Cheetham et al., 2013). Eles têm sido descritos em diversos processos biológicos e patológicos (Zhaoet al., 2013; Herriges, et al., 2014; Reddy et al., 2014) e no câncer, já foi demonstrado que podem atuar tanto como supressores tumorais (Russell et al., 2015) quanto como oncogenes (Colombo et al., 2015). Em câncer de mama já foi demonstrado que um perfil consistindo exclusivamente de IncRNAs está associado a risco de metástase em pacientes com câncer de mama linfonodo negativo, independentemente dos marcadores clínicos tradicionais, tais como tamanho do tumor e status do receptor de 
estrogênio (Sørensen et al., 2015). A expressão aberrante no câncer de mama de alguns RNAs, como HOTAIR, MALAT1, XIST e BC200, é indicativo que os IncRNAs podem ser utilizados como fatores prognósticos e de terapia (Song et al., 2015) e com o avanço dos estudos, novos IncRNAs têm sido descobertos e novas funções têm sido atribuídas àqueles já conhecidos. Um bom exemplo é o caso do PANDAR, IncRNA envolvido na regulação da resposta apoptótica em resposta a dano no DNA (Hung et al., 2011) que recentemente foi sugerido como promotor de tumor e regulador do ciclo celular de células do câncer de mama (Sang et al., 2016).

O presente estudo buscou analisar a expressão de IncRNAs em amostras metastáticas pareadas com seus tumores primários correspondentes, utilizando para isso a técnica RNASeq. Foi obtido um total de quarenta amostras, correspondentes a vinte pares de tumores primários e metastáticos. De acordo com as informações contidas nos prontuários das pacientes, foi possível classificar as amostras de mama nos seus subtipos moleculares - a maioria (65\%) do subtipo HER2, $25 \%$ dos subtipos luminal A e B (por falta de informações adicionais sobre o estado proliferativo dos tumores - pela expressão do marcador Ki-67 - os subtipos luminais foram classificados como um único grupo) e apenas uma amostra triplo negativa. No Brasil, o tipo histológico mais frequente, de acordo com Carvalho e cols. (2010), é o luminal A, representando $55 \%$ dos casos de carcinoma invasivo de mama. Provavelmnte devido ao pequeno número amostral, as frequências dos subtipos histológicos encontradas no presente estudo divergiu desse dado. O carcinoma ductal invasivo é o subtipo morfológico mais comum, representando $80 \%$ dos carcinomas invasivos (Rivenbark; O'Connor; Coleman, 2013), mesma proporção encontrada nas amostras deste estudo.

A análise da qualidade do sequenciamento dos cinco pares tumorais selecionados demonstrou que o resultado é altamente confiável. A qualidade é baseada no escore Phred (valor bruto de qualidade), que é calculado como a função log da probabilidade da chamada de base estar incorreta (Ruffalo et al., 2012). O escore é calculado para cada chamada de base na read e varia de zero a quarenta, sendo zero o menos e quarenta o mais confiável. Neste estudo, todas as posições das reads geradas apresentaram um escore acima de 30, que corresponde a uma baixa probabilidade (1/1000) da chamada de base estar incorreta (Ewing e Green, 1998). 
Após a avaliação da qualidade do sequenciamento, as sequências foram mapeadas contra o genoma de referência GRCh37.p13, o que revelou que aproximadamente 55\% das reads de todos os grupos amostrais mapearam em regiões de RNA não codificador de proteína - predominantemente regiões de IncRNAs - enquanto que cerca de $35 \%$ foram mapeados em regiões codificadoras. O maior número de IncRNAs em relação aos mRNAs está de acordo com estudo de lyer e cols. (2015), no qual encontraram que a diversidade genômica de IncRNAs sobrepuja a de transcritos codificadores. Dentre os IncRNAs expressos, aqueles que retêm íntros são os mais abundantes, representando aproximadamente $60 \%$ de todos os IncRNAs de todos os grupos amostrais. A retenção de íntrons consiste justamente na manutenção de uma sequência intrônica no transcrito maduro, onde o íntron retido geralmente apresenta sítios de splicing mais fracos que fazem com que o spliceossomo não consiga identificá-los (Ge e Porse, 2013 apud Sakabe; Souza, 2007). Já foi demonstrado, que, juntamente com o éxon skipping, a retenção de íntron é um dos eventos de splicing predominantes em câncer de mama (Eswaran et al., 2013). A maioria dos íntrons retidos é específica do câncer de origem, ou seja, cânceres originados de tecidos similares exibem padrões de retenção intrônica similares (Dvinge e Bradley, 2015), o que pode explicar a semelhança no número de íntrons retidos entre os grupos tumorais. Essa característica parece se estender para as outras classes de IncRNAs, que também apresentaram número de transcritos similares entre as amostras. A análise dos diagramas de Venn também reforça essa ideia, uma vez que a grande maioria dos IncRNAs expressos nas metástases são também expressos nos seus respectivos tumores primários. Além disso, dados da literatura apontam que as mudanças de expressão de uma colônia metastática são sutis e que características biológicas significantes se mantêm similares entre o tumor primário e sua metástase correspondente (Weigelt e van't Veer, 2004). Além disso, observa-se que todos os tumores de mama compartilham um alto número de transcritos comuns, assim como todos os tumores metastáticos, o que indica que, qualitativamente, eles são muito semelhantes entre si.

Procurando saber quais seriam as funções dos IncRNAs que se encontravam comumente expressos nas amostras tumorais, foram realizadas buscas em bases de dados públicas. Verificou-se que a maioria dos genes de IncRNAs encontrados neste estudo ainda não possuem caracterização funcional. De fato, os papéis regulatórios de poucos IncRNAs já 
foram biologicamente caracterizados, devido, em grande parte, ao rápido acúmulo de dados de estudos de larga escala (Fritah; Niclou; Azuaje, 2014). Alguns IncRNAs já descritos na literatura como envolvidos no desenvolvimento e na progressão do câncer de mama encontravam-se expressos nas amostras tumorais, tanto primárias quanto metastáticas. Um dos que apresentou um dos maiores níveis de expressão em todas as amostras foi o MALAT1 (Metastasis-Associated Lung Adenocarcinoma Transcript 1), primeiramente descrito em associação com metástase em câncer de pulmão (Ji et al., 2003). Ele é altamente expresso em diversos tipos de câncer e promove motilidade celular através de regulação transcricional e pós-transcricional da expressão de genes relacionados a motilidade, como CCT4 e HMMR (Tano et al., 2010). Um estudo de meta-análise demonstrou que a incidência de metástases em linfonodo em pacientes com alta expressão de MALAT1 é maior que a de pacientes com baixa expressão desse IncRNA (Zhai et al., 2015) e, recentemente, foi demonstrado que a diminuição da expressão de MALAT1 resulta em alterações na expressão gênica e mudança nos padrões de splicing de genes envolvidos em diferenciação e vias de sinalização pró-tumorigênicas (Arun et al., 2016).Em todas as amostras tumorais, também foi encontrada alta expressão de XIST ( $X$ inactive specific transcript), bem conhecido pelo seu papel na inativação do cromossomo X (Cerase et al., 2015). Ele é encontrado altamente expresso em carcinoma de mama e a diminuição da sua expressão tem função supressora tumoral, reduzindo proliferação celular, migração, invasão e induzindo apoptose (Tantai et al., 2015). O BCYRN1 (brain cytoplasmic RNA 1), também conhecido como BC200, foi mais um dos genes de IncRNAs que apresentou alta expressão nas amostras tumorais, o que é corroborado por estudo mostrando que esse IncRNA é altamente expresso em carcinomas de mama invasivos (lacoangeli et al., 2004). O seu possível papel oncogênico está relacionado com sua função de regulador negativo da apoptose (Singh e Mo, 2015).

Outro IncRNA expresso nos tumores deste estudo foi o LINC00472 (Long intergenic nonprotein coding RNA 472). Em estudo recente, no qual ele foi caracterizado, curiosamente, foi observado que o LINC00472 estava associado com tumores de mama menos agressivos e que sua alta expressão podia suprimir a proliferação e migração das células do câncer de mama (Shen et al., 2015). A expressão desse IncRNA, tanto nas amostras de tumor primário quanto nas amostras metastáticas, não coloca seu papel antitumoral e questão, mas pode demonstrar que o balanço da expressão de oncogenes e 
genes supressores tumorais pode determinar a evolução do câncer. O LINC00472 foi escolhido para validação, devido à sua recente caracterização funcional e expressão nas amostras tumorais. A análise da PCR semi-quantitativa em seis pares tumorais demonstrou que o LINC00472 apresenta expressão variável entre as amostras, assim como foi observado nos dados de expressão (FPKM) do RNA-Seq, quando avaliados para cada amostra individualmente.

Estudo de Gupta e cols. (2010) demonstrou que HOTAIR (HOX antisense intergenic $R N A$ ) é altamente expresso em tumores primário de mama e suas metástases. Ele é necessário para o mecanismo de transição epitélio-mesenquimal e para a manutenção do fenótipo de célula-tronco em linhagem celular de câncer de mama (Pádua Alves et al., 2013), o que pode ser consequência da sua capaciade de interagir com o complexo repressivo policombe 2 (PRC2), guiando-o para sítios específicos e promovendo silenciamento transcricional e supressão de diferenciação celular (Zhang, J. et al., 2014). Nas amostras do presente estudo, HOTAIR encontrava-se bem expresso nos pares tumorais, porém com um nível de expressão menor se comparado com MALAT1, XIST, BCYRN1 e LINC00472, o que pode sugerir um certo grau de diferenciação das células tumorais. O ZFAS1 (zinc finger antisense 1), por sua vez, apresentou níveis de expressão comparativamente menores que os demais IncRNAs acima citados. Uma explicação possível é que esse IncRNA é provavelmente um gene supressor tumoral - estudo de Askarian-Amiri e cols. (2011) mostrou que a diminuição da expressão de Zfas1 em células epiteliais mamárias de camundongos aumentou significativamente a proliferação e a atividade metabólica celular.

Em seguida, foi avaliada a diferença nos níveis de expressão dos IncRNAs comuns entre as amostras de tumor primário e seus tumores metastáticos, para verificar quais os transcritos que poderiam estar envolvidos com o processo metastático. Dentre os genes dos IncRNAs diferencialmente expressos, apenas os codificadores de proteínas (que originam os transcritos com íntron retido) possuem função biológica descrita na literatura, com exceção de cinco IncRNAs: o 7SK, um IncRNA que atua interrompendo o alongamento transcricional (Kugel; Goodrich, 2012); o SOX2-OT, altamente expresso em células embrionárias e excerce função regulatória na progressão do ciclo celular (Shahryari et al., 2015); o DNM3OS, um IncRNA que contém três miRNAs e é indispensável para o desenvolvimento esquelético normal e o crescimento corporal em mamíferos (Watanabe et al., 2008); o TBX-AS1, 
envolvido na capacidade de crescimento independente de ancoragem de células cancerosas de cólon (Li et al., 2015); e, curiosamente, o MEG3, um IncRNA cujo gene tem a expressão perdida em diversos tumores primários e que atua inibindo a proliferação de células tumorais (Zhou et al., 2012).

Uma vez que a maior parte dos IncRNAs não possui função descrita, foi analisada a interação daqueles transcritos mais expressos com proteínas, a fim de inferir a função desses transcritos (Anexo E). Observou-se que a maioria entá envolvida no processamento de mRNA, principalmente na regulação de splicing alternativo, processo que oferece uma plasticidade importante para as células cancerosas remodelarem seus proteomas e suprirem suas necessidades de crescimento e metástase (David; Manley, 2010). Alguns IncRNAs, como o RP11-400N13.3-001 e o RP11-693J15.5-001, interagem com proteínas envolvidas na via de sinalização do receptor do fator de crescimento epidermal (EGFR). A superfamília EGFR é composta por diversas proteínas, das quais algumas podem atuar como fatores de crescimento pela ligação com receptores de membrana específicos (Normanno et al., 2001). Além disso, os membros dessa família são os principais participantes de uma complexa cascata de sinalização que, além de crescimento, regula diferenciação, migração, adesão e sobrevivência das células cancerosas (Seshacharyulu et al., 2012). Também foi identificada a interação de IncRNAs com proteínas relacionadas com a via de sinalização Notch, cujo papel oncogênico em câncer de mama provavelmente é mediado, em parte, pela sua interação com outras vias de sinalização, como a do estrógeno (Al-Hussaini et al., 2011). De forma geral, a via Notch determina o destino celular e regula a renovação de células-tronco normais e cancerosas, assim como diferenciação (Takebe; Nguyen; Yang, 2014). Além das vias já citadas, houve interação de IncRNAs com proteínas da via do TGF- $\beta$, que é uma via contexto-dependente e que excerce efeitos célula-específicos, podendo tanto estimular quanto inibir o crescimento, a apoptose ou a diferenciação (Jakowlew, 2006). A partir desses resultados, observa-se que, apesar de muitos IncRNAs não possuírem função conhecida, suas características funcionais podem ser inferidas a partir das suas interações com outras moléculas.

Em seguida, foi realizado o agrupamento hierárquico não supervisionado, que agrupou as amostras com base nas suas similaridades de IncRNAs diferencialmente expressos. Em 2003, Weigelt e cols. analisaram o perfil de expressão gênica entre oito pares de tumores 
primários de mama e suas metástases em sítios distantes, utilizando a técnica de microarranjo para mais de dezoito mil cDNAs. Os pesquisadores observaram que os tumores primários eram mais similares aos seus tumores metastáticos pareados que a outros tumores. Contrariamente ao achado de Weigelt e cols., neste estudo as amostras de tumores primários de mama eram mais similares entre si do que com seus correspondentes metastáticos. Da mesma forma, as amostras de metástase foram agrupadas em linfonodo e em cérebro, com exceção de uma amostra de linfonodo, que assemelhou mais com o grupo de tumores primários. Resultado similar foi encontrado por LaTulippe e cols. (2002), em estudo da diferença na expressão gênica entre tumores de próstata primários e metastáticos. A partir da análise não supervisionada da expressão gênica, o grupo observou forte tendência dos tumores primários e metastáticos apresentarem perfis de expressão bem distintos, sugerindo genes específicos responsáveis pelas diferenças biológicas entre os dois grupos. No presente estudo, foram identificadas três assinaturas de IncRNAs bem distintas entre os grupos amostrais, o que sugere a presença de IncRNAs específicos responsáveis pela distinção biológica de cada tipo de tumor metastático e dos tumores primários. Além disso, a diferença de expressão desses IncRNAs pode indicar possível envolvimento desses transcritos no mecanismo de metástase. 


\section{CONCLUSÕES}

1. Determinação o perfil de expressão de IncRNAs de tumor de mama metastático em cérebro e em linfonodo;

Foram obtidos com sucesso perfis de expressão de IncRNAs de tumores primários de mama e suas respectivas metástases em linfonodo e em cérebro

2. Classificação funcionaldos IncRNAs preferencialmente expressos nos tumores metastáticos;

A maioria dos IncRNAs expressos nas amostras deste estudo ainda não são funcionalmente caracterizados

3. Seleção de IncRNAs potencialmente envolvidos com a metástase.

Foram identificados três assinaturas de IncRNAs, uma para cada grupo tumoral.

Em resumo, os resultados indicam que os IncRNAs diferencialmente expressos que compõem as assinaturas podem estar envolvidos no mecanismo de metástase e são potenciais candidatos

para estudos

funcionais. 


\section{REFERÊNCIAS}

Al-Hussaini, H. et al. Notch Signaling Pathway as a Therapeutic Target in Breast Cancer. Molecular Cancer Therapeutics, v. 10, n. 1, p. 9-15, 2011.

Alitalo, K.; Tammela, T.; Petrova, T. V. Lymphangiogenesis in development and human disease. Nature, v. 438, 946-953, 2005.

Aloraifi, F. et al. Detection of novel germline mutations for breast cancer in nonBRCA1/2 families. The FEBS Journal, v. 282, n. 17, p. 3424-3427, 2015.

Antoniou, A. C. et al. Breast-cancer risk in families with mutations in PALB2. The New England Journal of Medicine, v. 371, n. 6, p. 497-506, 2014.

Amendola, L. C. B.; Vieira, R. A contribuição dos genes BRCA na predisposição hereditária ao câncer de mama. Revista Brasileira de Cancerologia, v. 51, n. 4, p.325-330, 2005.

American Cancer Society. Cancer Facts \& Figures, American Cancer Society, 2016. Disponível em < http://www.cancer.org/research/cancerfactsstatistics/cancerfactsfigures2016/index > Acesso em 10 de fevereiro de 2016.

Anderberg, C. et al. Deficiency for endoglin in tumor vasculature weakens the endothelial barrier to metastatic dissemination. The Journal of Experimental Medicine, v. 210, n. 3, p. 563-579, 2013.

Anders, S.; Pyl, P. T.; Huber, W. HTSeq - A Python framework to work with high-throughput sequencing data. Bioinformatics, v. 31, n. 2, p. 166-169, 2014.

Ard, R.; Tong, P.; Allshire, R. C. Long non-coding RNA-mediated transcriptional interference of a permease gene confers drug tolerance in fission yeast. Nature Communications, v. 5, p. 5576, 2013.

Arun, G. et al. Differentiation of mammary tumors and reduction in metastasis upon Malat1 IncRNA loss. Genes \& Development, v. 30, p. 34-51, 2016.

Askarian-Amiri, M. E. et al. SNORD-host RNA Zfas1 is a regulator of mammary development and a potential marker for breast cancer. RNA, v. 17, n. 5, p. 878-891, 2011. 
Babraham Intitute. FastQC. Babraham Bioinformatics, 2014. Disponível em < http://www.bioinformatics.babraham.ac.uk/projects/fastqc/> acesso em 17 de janeiro de 2016.

Badve, S.; Gökmen-Polar, Y. Tumor heterogeneity on breast cancer. Advances in Anatomic Pathology, v. 22, n. 5, p. 294-302, 2015.

Baker, M. Long noncoding RNAs: the search for function. Nature Methods, v. 8, n. 5, p. 379383, 2011.

Ban, K. A.; Godellas, C. V. Epidemiology of breast cancer. Surgical Oncology Clinics of North America, v. 23, n. 3, p. 409-422, 2014.

Bànkfalvi, A. et al. Immunophenotypic and prognostic analysis of E-cadherin and betacatenin expression during breast carcinogenesis and tumour progression: a comparative study with CD44. Histopathology, v. 34, n. 1, p. 25-34, 1999.

Bastos, E. P. et al. MicroRNAs discriminate familial from sporadic nonBRCA1/2 breast carcinoma arising in patients $\leq 35$ years. PLoS One, v. 9, n. 7, e101656, 2014.

Bergmann, J. H.; Spector, D. L. Long non-coding RNAs: modulators of nuclear structure and function. Current Opinion in Cell Biology, v. 26, p. 10-18, 2014.

Berteaux, N. et al. H19 mRNA-like noncoding RNA promotes breast cancer cell proliferation through positive control by E2F1. The Journal of Biological Chemistry, v. 280, p. 2962529636, 2005.

Bissell, M. J.; Rizki, A.; Mian, I. S. Tissue architecture: the ultimate regulator of breast epithelial function. Current Opinion in Cell Biology, v. 15, n. 6, p. 753-762, 2003.

Brábek, J. et al. The role of the tissue microenvironment in the regulation of cancer cell motility and invasion. Cell Communication and Signaling, v. 8, p. 22, 2010.

Brannan, C. I. et al. The product of the $\mathrm{H} 19$ gene may function as an RNA. Mollecular and Cellular Biology, v. 10, n. 1, p. 28-36, 1990. 
Branham, M. T. et al. Epigenetic regulation of ID4 in the determination of the BRCAness phenotype in breast cancer. Breast Cancer Research and Treatment, v. 155, n. 1, p. 13-23, 2016.

Braunschweig, $U$. et al. Widespread intron retention in mammals functionally tunes transcriptomes. Genome Research, v. 24, p. 1774-1786, 2014.

Bravo-Cordero, J. J.; Hodgson, L.; Condeelis, J. Directed cell invasion and migration during metastasis. Current Opinion in Cell Biology, v. 24, n. 2, p. 277-283, 2012.

Bubien, V. et al. High cumulative risks of cancer in patients with PTEN hamartoma tumour syndrome. Journal of Medical Genetics, v. 50, p. 255-263, 2013.

Buerguer, $\mathrm{H}$. et al. Genetic relation of lobular carcinoma in situ, ductal carcinoma in situ, and associated invasive carcinoma of the breast. Journal of Clinical Pathology: Molecular Pathology, v. 53, p. 118-121, 2000.

Burstein, H. J. et al. Ductal Carcinoma in Situ of the Breast. The New England Journal of Medicine, v. 350, p. 1430-1441, 2004.

Cabili, M. N. et al. Integrative annotation of human large intergenic noncoding RNAs reveals global properties and specific subclasses. Genes \& Development, v. 25, n. 18, p. 1915-1927, 2011.

Cai, X.; Cullen, B. R. The imprinted H19 noncoding RNA is a primary microRNA precursor. $R N A$, v. 13, p. 313-316, 2007.

Carvalho, L. V. et al. Molecular characterization of breast cancer in young Brazilian women. Revista da Associação Médica Brasileira, v. 56, n. 3, p. 278-287, 2010.

Cerase, A. et al. Xist localization and function: new insights from multiple levels. Genome biology, v. 16, n. 1, p. 166, 2015.

Chao, Y. L.; Shepard, C. R.; Wells, A. Research Breast carcinoma cells re-express E-cadherin during mesenchymal to epithelial reverting transition. Molecular Cancer, v. 9, p. 179, 2010.

Cheetham, S. W. et al. Long noncoding RNAs and the genetics of cancer. British Journal of Cancer, v. 108, p. 2419-2425, 2013. 
CHEK2 Breast Cancer Case-Control Consortium. CHEK2*1100delC and susceptibility to breast cancer: a collaborative analysis involving 10,860 breast cancercases and 9,065 controls from 10 studies. American Journal of Human Genetics, v. 74, n. 6, p. 1175-1182, 2004.

Chou, J. et al. MALAT1 induced migration and invasion of human breast cancer cells by competitively binding miR-1 with cdc42. Biochemical and Biophysical Research Communications, v. 472, n. 1, p. 262-269, 2016.

Colombo, T. et al. PVT1: A rising star among oncogenic long noncoding RNAs. BioMed Research International, v. 2015, artigo 304208, 10 p., 2015.

Cooke, V. G. et al. Pericyte depletion results in hypoxia-associated epithelial-tomesenchymal transition and metastasis mediated by Met signaling pathway. Cancer Cell, v. 21, n. 1, p. 66-81, 2012.

Curtit, E. et al. First description of a sporadic breast cancer in a woman with BRCA1 germline mutation. Oncotarget, v. 6, n. 34, p. 35616-35624, 2015.

Danza, K. et al. Combined microRNA and ER expression: a new classifier for familial and sporadic breast cancer patients. Journal of Translational Medicine, v. 12, p. 319, 2014.

David, C. J.; Manley, J. L. Alternative pre-mRNA splicing regulation in cancer: pathways and programs unhinged. Genes \& Development, v. 24, p.2343-2364, 2010.

de Boer, M. et al. Breast cancer prognosis and occult lymph node metastases, isolated tumor cells, and micrometastases. Journl of the National Cancer Institute, v. 102, n. 6, p. 410-425, 2010.

Derrien, T. et al. The GENCODE v7 catalog of human long noncoding RNAs: Analysis of their gene structure, evolution, and expression. Genome Research, v. 22, p. 1775-1789, 2012.

Ding, X. et al. Long intergenic non-coding RNAs (LincRNAs) identified by RNA-Seq in breast cancer. PLoS One, v. 9, n. 8, e103270, 2014.

Domchek, S. M. Evolution of Genetic Testing for Inherited Susceptibility to Breast Cancer. Journal of Clinical Oncology, v. 33, n. 4, p. 295-296, 2015. 
Dvinge, H.; Bradley, R. K. Widespread intron retention diversifies most cancer transcriptomes. Genome Medicine, v. 7, n. 1, p. 45, 2015.

Economopoulou, P.; Dimitriades, G.; Psyrri, A. Beyond BRCA: New hereditary breast cancer susceptibility genes. Cancer Treatment Reviews, v. 41, n. 1, p. 1-8, 2015.

Eswaran, J. et al. RNA sequencing of cancer reveals novel splicing alterations. Scientific Reports, v. 3, artigo 1689, 2013.

Ewing, B.; Green, P. Base-calling of automated sequencer traces using Phred. II. Error probabilities. Genome Research, v. 8, p. 186-194, 1998.

Fritah, S.; Niclou, S. P.; Azuaje, F. Databases for IncRNAs: a comparative evaluation of emerging tools. RNA, v. 20, n. 11, p. 1655-1665, 2014.

Gallego Romero, I. et al. RNA-seq: impact of RNA degradation on transcript quantification. BMC Biology, v. 12, p. 42, 2014.

Ge, Y.; Porse, B. T. The functional consequences of intron retention: Alternative splicing coupled to NMD as a regulator of gene expression. Bioessays, v. 36, p. 236-243, 2013.

Gialeli, C.; Theocharis, A. D.; Karamanos, N. K. Roles of matrix metalloproteinases in cancer progression and their pharmacological targeting. FEBS Journal, v. 278, n. 1, p. 16-27, 2011.

Gil-Barnabé, A. M.; Lucotti, S.; Muschel, R. J. Coagulation and metastasis: what does the experimental literature tell us? British Journal of Haematology, v. 162, n. 4, p. 433-41, 2013.

Guil, S.; Esteller, M. Cis-acting noncoding RNAs: friends and foes. Nature Structural \& Molecular Biology, v. 19, p. 1068-1075, 2012.

Gupta, R. A. et al. Long non-coding RNA HOTAIR reprograms chromatin state to promote cancer metastasis. Nature, v. 464, p. 1071-1078, 2010.

Gutschner, T.; Diederichs, S. The hallmarks of cancer: a long non-coding RNA point of view. RNA Biology, v. 9, n. 6, p. 703-719, 2012.

Hajjari, M.; Salavaty, A. HOTAIR: an oncogenic long non-coding RNA in different cancers. Cancer Biology \& Medicine, v. 12, n. 1, p. 1-9, 2015. 
Han, P.; Chang, C. P. Long non-coding RNA and chromatin remodeling. RNA Biology, v. 12, n. 10, p. 1094-1098, 2015.

Hangauer, M. J.; Vaughn, I. W.; McManus, M. T. Pervasive transcription of the human genome produces thousands of previously unidentified long intergenic noncoding RNAs. PLoS Genetics, v. 9, n. 6, e1003569, 2013.

Hansji, H. et al. Keeping abreast with long non-coding RNAs in mammary gland development and breast cancer. Frontiers in Genetics, v. 5, 379, 2014.

Henry, N. L.; Haynes, D. F. Cancer biomarkers. Molecular Oncology, v. 6, n. 2, p. 140-146, 2012.

Herriges, M. J. et al. Long noncoding RNAs are spatially correlated with transcription factors and regulate lung development. Genes \& Development, v. 28, p. 1363-1379, 2014.

Herschkowitz, J. I. et al. Identification of conserved gene expression features between murine mammary carcinoma models and human breast tumors. Genome Biology, v. 8, n. 5, R76, 2007.

Hiemer, S. E.; Szymaniak, A. D.; Varelas, X. The transcriptional regulators TAZ and YAP direct transforming growth factor $\beta$-induced tumorigenic phenotypes in breast cancer cells. The Journal of Biological Chemistry, v. 289, n. 19, p. 13461-13474, 2014.

$\mathrm{Hu}, \mathrm{M}$. et al. Regulation of in situ to invasive breast carcinoma transition. Cancer Cell, v. 13, n. 5, p. 394-406, 2008.

Hung, T. et al. Extensive and coordinated transcription of noncoding RNAs within cell-cycle promoters. Nature Genetics, v. 43, p. 621-629, 2011.

lacoangeli, A. et al. BC200 RNA in invasive and preinvasive breast cancer. Carcinogenesis, v. 25, n. 11, p. 2125-2133, 2004.

llott, N. E.; Ponting, C. P. Predicting long non-coding RNAs using RNA sequencing. Methods, v. 63, n. 1, p. 50-59, 2013. 
Instituto Nacional do Câncer. Tipos de câncer - mama. INCA, 2016. Disponível em < http://www2.inca.gov.br/wps/wcm/connect/tiposdecancer/site/home/mama > acesso em 10 de fevereiro de 2016.

Iyer, M. K. et al. The landscape of long noncoding RNAs in the human transcriptome. Nature Genetics, v. 47, p. 199-208, 2015.

Jakowlew, S. B. Transforming growth factor- $\beta$ in cancer and metastasis. Cancer Metastasis Reviews, v. 25, p. 3, p. 435-457, 2006.

$\mathrm{Ji}$, P. et al. MALAT-1, a novel noncoding RNA, and thymosin $\beta 4$ predict metastasis and survival in early-stage non-small cell lung cancer. Oncogene, v. 22, p. 8031-8041, 2003.

Jones, P. A.; Baylin, S. B. The epigenomics of cancer. Cell, v. 128, p. 683-692, 2007.

Kallen, A. N. et al. The imprinted H19 IncRNA antagonizes let-7 microRNAs. Molecular Cell, v. 52, n. 1, p. 101-112, 2013.

Kamińska, M. et al. Breast cancer risk factors. Prz Menopauzalny, v. 14, n. 3, p. 196-202, 2015.

Kanada, M. et al. Endothelial cell-initiated extravasation of cancer cells visualized in zebrafish. PeerJ, v. 2, e688, 2014.

Karaman, S.; Detmar, M. Mechanisms of lymphatic metastasis. Journal of Clinical Investigation, v. 124, n. 3, p. 922-928, 2014.

Khachane, A. N.; Harrison, P. M. Mining mammalian transcript data for functional long noncoding RNAs. PLoS One, v. 5, n. 4, e10316, 2010.

Khuon, S. et al. Myosin light chain kinase mediates transcellular intravasation of breast cancer cells through the underlying endothelial cells: a three-dimensional FRET study. Journal of Cell Science, v. 123, p. 431-440, 2010.

Knowles, L. M. et al. Fibronectin matrix formation is a prerequisite for colonization of kidney tumor cells in fibrin. Journal of Cancer, v. 6, n. 2, p. 98-104, 2015. 
Konstantopoulos, K.; Thomas, S. N. Cancer cells in transit: the vascular interactions of tumor cells. Annual Review of Biomedical Engineering, v. 11, p. 177-202, 2009.

Kornblihtt, A. R. et al. Alternative splicing: a pivotal step between eukaryotic transcription and translation. Nature Reviews Molecular Cell Biology, v. 14, p. 153-165, 2013.

Koren, S.; Betires-Alj, M. Breast tumor heterogeneity: source of fitness, hurdle for therapy. Molecular Cell, v. 60, n. 4, p. 537-546, 2015.

Kornienko, A. E. et al. Long non-coding RNAs display higher natural expression variation than protein-coding genes in healthy humans. Genome Biology, v. 17, n. 1, p. 14, 2016.

Koujan, S. E.; Gargarib, B. P.; Khalili, M. Matrix metalloproteinases and breast cancer. Thrita, v. 4, n. 1, e21959, 2015.

Kugel, J. F.; Goodrich, J. A. Non-coding RNAs: key regulators of mammalian transcription. Trends in Biochemical Sciences, v. 37, n. 4, p. 144-151, 2012.

Kukurba, K. R.; Montgomery, S. B. RNA sequencing and analysis. Cold Spring Harbor Protocols, 2015.

Labelle, M.; Hynes, R. O. The initial hours of metastasis: the importance of cooperative hosttumor cell interactions during hematogenous dissemination. Cancer Discovery, v. 2, n. 12, p. 1091-1099, 2012.

Lamouille, S.; Xu, J.; Derynck, R. Molecular mechanisms of epithelial-mesenchymal transition. Nature Reviews Molecular Cell Biology, v. 15, n. 3, p. 178-196, 2014.

LaTulippe, E. et al. Comprehensive Gene Expression Analysis of Prostate Cancer Reveals Distinct Transcriptional Programs Associated with Metastatic Disease. Cancer Research, v. 62, n. 15, p. 4499-4506, 2002.

Leber, M. F.; Efferth, T. Molecular principles of cancer invasion and metastasis (Review). International Journal of Oncology, v. 34, p. 881-895, 2009.

Lee, J. T. Epigenetic regulation by long noncoding RNAs. Science, v. 338, n. 6113, p. 14351439, 2012. 
Lehmann, B. D. et al. Identification of human triple-negative breast cancer subtypes and preclinical models for selection of targeted therapies. The Journal of Clinical Investigation, v. 121, n. 7, p. 2750-2767, 2011.

Leong, H. S. et al. Invadopodia are required for cancer cell extravasation and are a therapeutic target for metastasis. Cell Reports, v. 8, n. 5, p. 1558-1570, 2014.

Lerner-Ellis, J. et al. Genetic risk assessment and prevention: the role of genetic testing panels in breast cancer. Expert Review of Anticancer Therapy, v. 15, n. 11, p. 1315-1326, 2015.

$\mathrm{Li}, \mathrm{H}$. et al. Circulating Prostaglandin Biosynthesis in Colorectal Cancer and Potential Clinical Significance. EBioMedicine, v. 2, n. 2, p. 165-171, 2015.

Li, L. et al. Long non-coding RNA MALAT1 promote triple-negative breast cancer progression by regulating miR-204 expression. International Journal of Clinical and Experimental Pathology, v. 9, n. 2, p. 969-977, 2016.

Li, Y. M. et al. Upregulation of CXCR4 is essential for HER2-mediated tumor metastasis. Cancer Cell, v. 6, n. 5, p. 459-469, 2004.

Liu, J. C. et al. Common and distinct features of mammary tumors driven by Pten-deletion or activating Pik3ca mutation. Oncotarget, v. 7, n. 8, p. 9060-9068, 2016.

Liu, Z.; Zhang, X. S.; Zhang, S. Breast tumor subgroups reveal diverse clinical prognostic power. Scientific Reports, v. 4, p. 4002, 2014.

Lottin, S. et al. Overexpression of an ectopic $\mathrm{H} 19$ gene enhances the tumorigenic properties of breast cancer cells. Carcinogenesis, v. 23, n. 11, p. 1885-1895, 2002.

Love, M. I.; Huber, W.; Anders, S. Moderated estimation of fold change and dispersion for RNA-seq data with DESeq2. Genome Biology, v. 15, p. 550, 2014.

Malih, S.; Saidijam, M.; Malih, N. A brief review on long noncoding RNAs: a new paradigm in breast cancer pathogenesis, diagnosis and therapy. Tumour Biology, 2015. No prelo. Disponível em: <http://link.springer.com/article/10.1007\%2Fs13277-015-4572-y > Acesso em 9 jan. 2016. 
Mangone, F. R. et al. ATM gene mutations in sporadic breast cancer patients from Brazil. Springerplus, v. 4, p. 23, 2015.

Massink, M. P. G. et al. Genomic profiling of CHEK2*1100delC-mutated breast carcinomas. BMC Cancer, v. 15, p. 877, 2015.

Mattick, J. S. The functional genomics of noncoding RNA. Science, v. 309, n. 5740, p. 15271528, 2005.

Melchor, L. et al. Identification of cellular and genetic drivers of breast cancer heterogeneity in genetically engineered mouse tumour models. The Journal of Pathology, v. 233, n. 2, p. 124-137, 2014.

Michailidou, K. et al. Genome-wide association analysis of more than 120,000 individuals identifies 15 new susceptibility loci for breast cancer. Nature Genetics, v. 47, n. 4, p. 373-380, 2015.

Mueller, B. M. et al. Expression of tissue factor by melanoma cells promotes efficient hematogenous metastasis. PNAS, v. 89, p. 11832-11836, 1992.

Müller, A. et al. Involvement of chemokine receptors in breast cancer metastasis. Nature, v. 410, p. 50-56, 2001.

Nathanson, S. D. Insights into the mechanisms of lymph node metastasis. Cancer, v. 98, n. 2, p. 413-423, 2003.

Nazário, A. C. P.; Facina, G.; Filassi, J. R. Breast cancer: news in diagnosis and treatment. Revista da Associação Médica Brasileira, v. 61, n. 6, p. 543-552, 2015.

Nguyen, D. X.; Bos, P. D.; Massagué, J. Metastasis: from dissemination to organ-specific colonization. Nature Reviews Cancer, v. 9, p. 274-284, 2009.

Nickels, S. et al. Evidence of gene-environment interactions between common breast câncer susceptibility loci and established environmental risk factors. Plos Genetics, v. 9, n. 3, p. e1003284, 2013. 
Nie, N. et al. Long non-coding RNAs: versatile master regulators of gene expression and crucial players in cancer. American Journal of Translational Research, v. 4, n. 2, p. 127-150, 2012.

Nisticò, P.; Bissel, M. J.; Radisky, D. C. Epithelial-mesenchymal transition: General principles and pathological relevance with special emphasis on the role of matrix metalloproteinases. Cold Spring Harbor Perspectives in Biology, v. 4, p. a011908, 2012.

Normanno, N. et al. The role of EGF-related peptides in tumor growth. Frontiers in Bioscience, v. 6, p. D685-707, 2001.

Pádua Alves, C. et al. Brief Report: The lincRNA Hotair is required for epithelial-tomesenchymal transition and stemness maintenance of cancer cell Lines. Stem Cells, v. 31, n. 12, p. 2827-2832, 2013.

Palumbo, J. S. et al. Platelets and fibrin(ogen) increase metastatic potential by impeding natural killer cell-mediated elimination of tumor cells. Blood, v. 105, n. 1, p. 178-185, 2005.

Pecorino, L. Molecular Biology of Cancer: Mechanisms, Targets, and Therapeutics. 3a ed. Oxford: Oxford University Press, 2012.

Perou, C. M. et al. Molecular portraits of human breast tumours. Nature, v. 406, p. 747-752, 2000.

Pignatelli, J. et al. Invasive breast carcinoma cells from patients exhibit Mena ${ }^{\text {INV }}$ - and macrophage-dependent transendothelial migration. Science Signaling, v. 7, n. 253, ra112, 2014.

Polyak, K. Breast cancer: origins and evolution. The Journal of Clinical Investigation, v. 117, n. 11, p. 3155-3163, 2007.

Polyak, K. Heterogeneity in breast cancer. The Journal of Clinical Investigation, v. 121, n. 10, p. 3786-3788, 2011. 
Poumpouridou, N. et al. Development of a novel PTT assay for mutation detection in PALB2 large exons and PALB2 screening in medullary breast cancer. Familial Cancer, v. 15, n. 2, p. 183-191, 2015.

Quan, M.; Chen, J.; Zhang, D. Exploring the Secrets of Long Noncoding RNAs. International Journal of Melecular Sciences, v. 16, n. 3, p. 5467-5496, 2015.

R Core Team. R: A language and environment for statistical computing. $R$ Foundation for Statistical Computing, Vienna, Austria. 2012.

Rahman, M.; Mohammed, S. Breast cancer metastasis and the lymphatic system (Review). Oncology Letters, v. 10, p. 1233-1239, 2015.

Ravasi, T. et al. Experimental validation of the regulated expression of large numbers of noncoding RNAs from the mouse genome. Genome Research, v. 16, n. 1, p. 11-19, 2006.

Reddy, M. et al. Regulation of Inflammatory Phenotype in Macrophages by a DiabetesInduced Long Noncoding RNA. Diabetes, v. 63, n. 12, p. 4249-4261, 2014.

Reymond, N.; d'Água, B. B.; Ridley, A. J. Crossing the endothelial barrier during metastasis. Nature Reviews Cancer, v. 13, n. 12, p. 858-870, 2013.

Rinn, J. L. et al. Functional Demarcation of Active and Silent Chromatin Domains in Human HOX Loci by Non-Coding RNAs. Cell, v. 129, n. 7, p. 1311-1323, 2007.

Rivenbark, A. G.; O'Connor, S. M.; Coleman, W. B. Molecular and cellular heterogeneity in breast cancer: Challenges for personalized medicine. The American Journal of Pathology, v. 183, n. 4, p. 1113-1124, 2013.

Rizwan, A. et al. Metastatic breast cancer cells in lymph nodes increase nodal collagen density. Scientific Reports, v. 5, p. 10002, 2015.

Ruffalo, M. et al. Accurate estimation of short read mapping quality for next-generation genome sequencing. Bioinformatics, v. 28, n. 18, p. i349-i355, 2012.

Russell, M. R. et al. CASC15-S is a tumor suppressor IncRNA at the $6 \mathrm{p} 22$ neuroblastoma susceptibility locus. Tumor and Stem Cell Biology, v. 75, n. 15, p. 3155-3166, 2015. 
Sabatier, R. et al. Claudin-low breast cancers: clinical, pathological, molecular and prognostic characterization. Molecular Cancer, v. 13, p. 228, 2014.

Sakabe, N. J.; Souza, S. J. Sequence features responsible for intron retention in human. BMC Genomics, v. 8, p. 59, 2007.

Samatov, T. R. et al. Epithelial-mesenchymal transition: focus on metastatic cascade, alternative splicing, non-coding RNAs and modulating compounds. Molecular Cancer, v. 12, p. 107, 2013.

Sana, M.; Malik, H. J. Current and emerging breast cancer biomarkers. Journal of Cancer Research and Therapeutics, v. 11, n. 3, p. 508-513, 2015.

Sang, Y. et al. LncRNA PANDAR regulates the G1/S transition of breast cancer cells by suppressing p16 ${ }^{\text {INK4A }}$ expression. Scientific Reports, v. 6, artigo 22366, 2016.

Scalia-Wilbur, J. et al. Breast cancer risk assessment: moving beyond BRCA 1 and 2. Seminars in Radiation Biology, v. 26, n. 1, p. 3-8, 2016.

Seshacharyulu, P. et al. Targeting the EGFR signaling pathway in cancer therapy. Expert Opinion on Therapeutic Targets, v. 16, n. 1, p. 15-31, 2012.

Shahryari, A. et al. Long non-coding RNA SOX2OT: expression signature, splicing patterns, and emerging roles in pluripotency and tumorigenesis. Frontiers in Genetics, v. 6, p. 196, 2015.

Sheikh, A. et al. The spectrum of genetic mutations in breast cancer. Asian Pacifi Journal of Cancer Prevention, v. 16, n. 6, p. 2177-2185, 2015.

Shen, Y. et al. Prognostic and predictive values of long non-coding RNA LINCO0472 in breast cancer. Oncotarget, v. 6, n. 11, p. 8579-8592, 2015.

Shendure, J.; Ji, H. Next-generation DNA sequencing. Nature Biotechnology, v. 26, p. 11351145, 2008.

Shi, X. et al. Long non-coding RNAs: A new frontier in the study of human diseases. Cancer Letters, v. 339, p. 159-166, 2013. 
Shibue, T.; Weinberg, R. A. Metastatic colonization: Settlement, adaptation and propagation of tumor cells in a foreign tissue environment. Seminars in Cancer Biology, v. 21, n. 2, p. 99106, 2011.

Shore, A. N.; Rosen, J. M. Regulation of mammary epithelial cell homeostasis by IncRNAs. The International Journal of Biochemistry \& Cell Biology, v. 54, p. 318-330, 2014.

Sibbering, M.; Courtney, C. A. Management of breast cancer: basic principles. Surgery, 2015. Sigurgeirsson, B. et al. Sequencing degraded RNA addressed by 3' tag counting. PLoS One, v. 9, n. 3, e91851, 2014.

Silva, J. M. et al. Identification of Long stress-induced non-coding transcripts that have altered expression in cancer. Genomics, v. 95, n. 6, p. 355-362, 2010.

Silva, J. M. et al. LSINCT5 is over expressed in breast and ovarian cancer and affects cellular proliferation. RNA Biology, v. 8, n. 3, p. 496-505, 2011.

Singh, R.; Mo, Y. Y. LncRNA BC200 is induced by estradiol and regulates apoptosis in MCF-7 breast cancer cells. Cancer Research, v. 75, p. 156, 2015.

Smigal, C. et al. Trends in breast cancer by race and ethnicity: update 2006. CA Cancer Journal for Clinicians, v. 56, p. 168-183, 2006.

Song, J. et al. The research progression of correlation between long non-coding RNA and breast cancer. Computacional Molecular Biology, v. 5, n. 2, p. 1-4, 2015.

Sørensen, K. P. et al. Long non-coding RNA expression profiles predict metastasis in lymph node-negative breast cancer independently of traditional prognostic markers. Breast Cancer Research, v. 17, p. 55, 2015.

Sotiriou, C.; Pusztai, L. Gene-expression signatures in breast cancer. The New England Journal of Medicine, v. 360, p. 790-800, 2009.

St. Laurent, G. et al. The Landscape of long noncoding RNA classification. Trends in Genetics, v. 31, n. 5, p. 239-251, 2015. 
Stoletov, K. et al. Visualizing extravasation dynamics of metastatic tumor cells. Journal of Cell Science, v. 123, p. 2332-2341, 2010.

$\mathrm{Su}, \mathrm{X}$. et al. Comprehensive analysis of long non-coding RNAs in human breast cancer clinical subtypes. Oncotarget, v. 5, n. 20, p. 9864-9876, 2014.

Takebe, N.; Nguyen, D.; Yang, S. X. Targeting notch signaling pathway in cancer: clinical development advances and challenges. Pharmacology and Therapeutics, v. 141, n. 2, p. 140149, 2014.

Tano, K. et al. MALAT-1 enhances cell motility of lung adenocarcinoma cells by influencing the expression of motility-related genes. FEBS Letters, v. 584, n. 22, p. 4575-4580, 2010.

Tantai, J. et al. Combined identification of long non-coding RNA XIST and HIF1A-AS1 in serum as an effective screening for non-small cell lung cancer. International Journal of Clinical and Experimental Pathology, v. 8, n. 7, p. 7887-7895, 2015.

Thiery, J. P. Epithelial-mesenchymal transitions in tumor progression. Nature Reviews Cancer, v. 2, p. 6, p. 442-454, 2002.

Thiery, J. P.; Sleeman, J. P. Complex networks orchestrate epithelial-mesenchymal transitions. Nature Reviews. Molecular Cell Biology, v. 7, n. 2, p. 131-142, 2006.

Thiery, J. P. et al. Epithelial-mesenchymal transitions in development and disease. Cell, v. 139, p. 871-890, 2009.

Trapnell, C. et al. Transcript assembly and quantification by RNA-Seq reveals unannotated transcripts and isoform switching during cell differentiation. Nature Biotechnology, v. 28, n. 5, p. 511-515, 2010.

Tuo, Y. L. et al. Long noncoding RNA UCA1 modulates breast cancer cell growth and apoptosis through decreasing tumor suppressive miR-143. European Review for Medical and Pharmacological Sciences, v. 9, n. 18, p. 3403-3411, 2015.

Vara, J. A. F. et al. PI3K/Akt signalling pathway and cancer. Cancer Treatments Reviews, v. 30, n. 2, p. 193-204, 2004. 
Visvader, J. E.; Stingl, J. Mammary stem cells and the differentiation hierarchy: current status and perspectives. Genes \& Development, v. 28, p. 1143-1158, 2014.

Vikram, R. et al. Functional significance of long non-coding RNAs in breast cancer. Breast Cancer, v. 21, p. 515-521, 2014.

Vymetalkova, V. et al. Genotype and haplotype analyses of TP53 gene in breast cancer patients: association with risk and clinical outcomes. Plos One, v. 10, n. 7, e0134463, 2015.

Watanabe, T. et al. Dnm3os, a non-coding RNA, is required for normal growth and skeletal development in mice. Developmental Dynamics, v. 237, n. 12, p. 3738-3748, 2008.

Wculek, S. K.; Malanchi, I. Neutrophils support lung colonization of metastasis-initiating breast cancer cells. Nature, v. 528, p. 413-417, 2015.

Weigelt, B. et al. Gene expression profiles of primary breast tumors maintained in distant metástases. PNAS, v. 100, n. 26, p 15901-15905, 2003.

Weigelt, B.; van't Veer, L. J. Hard-wired genotype in metastatic breast cancer. Cell Cycle, v. 3, n. 6, p. 756-757, 2004.

Wong, S. Y.; Hynes, R. O. Lymphatic or hematogenous dissemination: How does a metastatic tumor cell decide? Cell Cycle, v. 5, n. 8, p. 812-817, 2006.

Yadav, P. et al. Clinical significance of TP53 (R72P) and MDM2 (T309G) polymorphisms in breast cancer patients. Clinical and Translational Oncology, 2015. [Epub ahead of print]

Yao, D. et al. Mechanism of the mesenchymal-epithelial transition and Its relationship with metastatic tumor formation. Molecular Cancer Research, v. 9, n. 12, p. 1608-1620, 2011.

Yarden, Y. Biology of HER2 and its importance in breast cancer. Oncology, v. 61, supl. 2, p. 113, 2001.

Zervantonakis, I. K. et al. Three-dimensional microfluidic model for tumor cell intravasation and endothelial barrier function. PNAS, v. 109, n. 34, p. 13515-13520, 2012. 
Zhai, $H$. et al. Long noncoding RNA MALAT1 as a putative biomarker of lymph node metastasis: a meta-analysis. International Journal of Clinical and Experimental Meddicine, v. 8, n. 5, p. 7648-7654, 2015.

Zhang, J. et al. Long non-coding RNA HOTAIR in carcinogenesis and metastasis. Acta Biochimica et Biophysica Sinica, v. 46, n. 1, p. 1-5, 2014.

Zhang, L.; Long, X. Association of BRCA1 promoter methylation with sporadic breast cancers: Evidence from 40 studies. Scientific Reports, v. 5, p. 17869, 2015.

Zhang, M. et al. Intratumoral heterogeneity in a p53 null mouse model of human breast cancer. Cancer Discovery, v. 5, n. 5, p. 520-533, 2015.

Zhao, X. et al. A long noncoding RNA contributes to neuropathic pain by silencing Kcna2 in primary afferent neurons. Nature Neuroscience, v. 16, n. 8, p. 1024-1031, 2013.

Zhou, Y. et al. MEG3 noncoding RNA: a tumor suppressor. Journal of Molecular Endocrinology, v. 48, n. 3, p. R45-R53, 2012.

Zhu, X. et al. Hypermethylation of BRCA1 gene: implication for prognostic biomarker and therapeutic target in sporadicprimary triple-negative breast cancer. Breast Cancer Research and Treatment, v. 150, n. 3, p. 479-486, 2015. 


\section{ANEXOS}

Anexo A - IncRNAs mais expressos nos tumores primários de mama que deram origem a metástases em linfonodo.

\begin{tabular}{|c|c|c|c|}
\hline IncRNA & Tipo & log2Fold change & $-\log 10 p a d j$ \\
\hline RP11-400N13.3-001 & lincRNA & 5,1545 & 3,8446 \\
\hline RP11-1002K11.1-001 & lincRNA & 4,7936 & 5,5971 \\
\hline STEAP2-008 & íntron retido & 4,7915 & 4,0258 \\
\hline RP11-40109.4-001 & antisenso & 4,7032 & 3,5113 \\
\hline RP3-333A15.2-001 & senso intrônico & 4,6637 & 2,5782 \\
\hline CTC-327F10.5-001 & antisenso & 4,3190 & 2,3502 \\
\hline RP11-680C21.1-001 & lincRNA & 4,2305 & 2,3940 \\
\hline RP5-1112F19.2-001 & lincRNA & 4,0882 & 2,6741 \\
\hline COL12A1-005 & íntron retido & 4,0711 & 2,1380 \\
\hline RP11-53019.1-002 & antisenso & 4,0100 & 2,0146 \\
\hline CA12-006 & íntron retido & 3,9923 & 2,4011 \\
\hline CTC-327F10.4-001 & antisenso & 3,7799 & 2,0664 \\
\hline GABRE-007 & íntron retido & 3,7584 & 2,1901 \\
\hline CORIN-006 & íntron retido & 3,7309 & 2,5782 \\
\hline MLPH-006 & íntron retido & 3,6362 & 2,9814 \\
\hline RP11-417E7.2-001 & lincRNA & 3,6254 & 2,2651 \\
\hline AC099684.1-001 & antisenso & 3,5935 & 2,6711 \\
\hline SCUBE2-004 & íntron retido & 3,4480 & 2,6784 \\
\hline RP11-62I21.1-001 & antisenso & 3,4129 & 3,1041 \\
\hline COL1A2-005 & íntron retido & 3,3705 & 3,5991 \\
\hline FAP-003 & íntron retido & 3,3574 & 2,6395 \\
\hline COL1A2-012 & íntron retido & 3,3304 & 3,6959 \\
\hline C7orf63-006 & íntron retido & 3,2892 & 2,9651 \\
\hline RP5-1027G4.3-001 & antisenso & 3,2791 & 2,3182 \\
\hline COL1A2-006 & íntron retido & 3,2747 & 3,5027 \\
\hline COL1A2-007 & íntron retido & 3,2726 & 2,8875 \\
\hline RP11-275F13.1-002 & antisenso & 3,2352 & 2,0084 \\
\hline PPP2R2C-006 & íntron retido & 3,2322 & 2,0510 \\
\hline COL1A2-009 & íntron retido & 3,2276 & 2,4920 \\
\hline COL1A2-004 & íntron retido & 3,1810 & 2,8728 \\
\hline RP11-709B3.2-001 & lincRNA & 3,1759 & 2,8984 \\
\hline COL1A2-002 & íntron retido & 3,1674 & 4,1515 \\
\hline
\end{tabular}


Anexo A - IncRNAs mais expressos nos tumores primários de mama que deram origem a metástases em linfonodo.

\begin{tabular}{|c|c|c|c|}
\hline IncRNA & Tipo & log2Fold change & -log10padj \\
\hline FAP-008 & íntron retido & 3,1416 & 2,0755 \\
\hline RP11-27M24.3-001 & lincRNA & 3,1306 & 2,4629 \\
\hline AC005162.5-001 & Antisenso & 3,1129 & 2,8926 \\
\hline MEG3-010 & lincRNA & 3,0941 & 2,5706 \\
\hline RP1-60N8.1-001 & senso intrônico & 3,0588 & 2,0746 \\
\hline RP11-86H7.7-001 & lincRNA & 3,0454 & 2,3304 \\
\hline LINC00702-003 & lincRNA & 2,9595 & 2,1075 \\
\hline RP11-5407.3-003 & íntron retido & 2,9445 & 2,3900 \\
\hline CTD-2127H9.1-002 & lincRNA & 2,9373 & 3,1113 \\
\hline AC004538.3-005 & Antisenso & 2,8811 & 2,0606 \\
\hline COL3A1-002 & íntron retido & 2,8567 & 2,9997 \\
\hline TBX5-AS1-001 & Antisenso & 2,6099 & 3,1113 \\
\hline FARP1-017 & íntron retido & 2,6000 & 2,5187 \\
\hline RP11-282K24.3-001 & senso intrônico & 2,4165 & 2,3316 \\
\hline MICAL2-003 & íntron retido & 2,3122 & 2,3957 \\
\hline AC092171.2-001 & Antisenso & 2,3067 & 2,1188 \\
\hline FN1-018 & íntron retido & 2,3044 & 2,2651 \\
\hline MICAL2-004 & íntron retido & 2,2461 & 2,1235 \\
\hline RP3-439F8.1-001 & Antisenso & 2,1898 & 2,8390 \\
\hline WWC2-010 & íntron retido & 2,1534 & 2,0118 \\
\hline PARVA-002 & íntron retido & 2,1202 & 2,4489 \\
\hline COL6A2-007 & íntron retido & 2,1149 & 2,8728 \\
\hline
\end{tabular}


Anexo B - IncRNAs mais expressos nos tumores primários de mama que deram origem a metástases em cérebro.

\begin{tabular}{|c|c|c|c|}
\hline IncRNA & Tipo & log2Fold change & -log10pad \\
\hline RP11-40109.4-001 & antisenso & 5,8546 & 4,7356 \\
\hline TBX5-AS1-001 & antisenso & 4,7860 & 5,9774 \\
\hline CORIN-006 & íntron retido & 4,6557 & 2,4248 \\
\hline RP11-62I21.1-001 & antisenso & 3,9247 & 2,9017 \\
\hline COL6A3-009 & íntron retido & 3,8251 & 7,4754 \\
\hline COL1A2-004 & íntron retido & 3,6172 & 2,5137 \\
\hline COL1A2-005 & íntron retido & 3,4980 & 2,7186 \\
\hline COL1A2-002 & íntron retido & 3,3056 & 3,6430 \\
\hline COL3A1-002 & íntron retido & 3,2436 & 2,7570 \\
\hline COL1A2-006 & íntron retido & 3,2351 & 2,0085 \\
\hline COL6A3-007 & íntron retido & 3,1903 & 2,1289 \\
\hline COL1A2-012 & íntron retido & 3,1779 & 2,2894 \\
\hline RP11-1002K11.1-001 & lincRNA & 3,0786 & 2,0879 \\
\hline LINC00861-001 & lincRNA & 3,0443 & 2,1658 \\
\hline RP11-426C22.4-001 & lincRNA & 3,0336 & 2,3791 \\
\hline DNM30S-001 & antisenso & 3,0147 & 2,5248 \\
\hline COL6A2-007 & íntron retido & 2,6669 & 2,7774 \\
\hline RP11-815J21.4-001 & antisenso & 2,0050 & 2,1254 \\
\hline
\end{tabular}


Anexo C - IncRNAs mais expressos nos tumores metástaticos de mama em linfonodo.

\begin{tabular}{|c|c|c|c|}
\hline IncRNA & Tipo & log2Fold change & -log10padj \\
\hline RP11-297B17.3-001 & antisenso & 5,8813 & 3,8676 \\
\hline RP11-164H13.1-001 & antisenso & 5,6246 & 3,4619 \\
\hline RP11-148021.6-001 & lincRNA & 5,2166 & 3,4262 \\
\hline CD22-011 & íntron retido & 5,0077 & 4,1515 \\
\hline MS4A1-009 & íntron retido & 4,8229 & 2,8875 \\
\hline LINC00494-004 & lincRNA & 4,8165 & 3,1041 \\
\hline RP11-138I18.2-001 & lincRNA & 4,6246 & 3,4103 \\
\hline RP11-344B23.2-001 & antisenso & 4,4494 & 2,1316 \\
\hline RP11-148021.4-001 & antisenso & 4,4285 & 3,0339 \\
\hline LRMP-004 & íntron retido & 4,3664 & 2,1947 \\
\hline RP11-693J15.5-001 & lincRNA & 4,3627 & 3,4009 \\
\hline U62631.5-001 & senso intrônico & 4,3556 & 3,1041 \\
\hline RP11-148021.2-001 & antisenso & 4,3334 & 2,9434 \\
\hline BLK-006 & íntron retido & 4,2860 & 2,8079 \\
\hline CHRM3-AS2-001 & antisenso & 4,2138 & 2,9434 \\
\hline TCL6-013 & íntron retido & 4,1232 & 2,4489 \\
\hline HVCN1-005 & íntron retido & 4,0361 & 2,6540 \\
\hline RP4-555D20.2-001 & lincRNA & 4,0311 & 2,7332 \\
\hline CTA-250D10.23-001 & lincRNA & 4,0209 & 3,2969 \\
\hline RP11-348F1.3-001 & antisenso & 4,0010 & 2,5398 \\
\hline FCRL2-002 & íntron retido & 3,9851 & 2,9882 \\
\hline LINC00402-001 & lincRNA & 3,9207 & 2,3870 \\
\hline CD79B-005 & íntron retido & 3,8682 & 2,1188 \\
\hline LINC00926-001 & lincRNA & 3,7919 & 3,1041 \\
\hline RP11-498M5.2-001 & antisenso & 3,7795 & 2,4384 \\
\hline RP11-428G5.5-001 & lincRNA & 3,7131 & 2,5740 \\
\hline RP11-554|8.1-001 & lincRNA & 3,6621 & 2,3597 \\
\hline RP11-16E12.1-002 & lincRNA & 3,6345 & 2,0975 \\
\hline FAM65B-004 & íntron retido & 3,5549 & 2,1222 \\
\hline AL928768.3-001 & lincRNA & 3,5333 & 2,1118 \\
\hline HLA-DOB-002 & íntron retido & 3,5221 & 2,4946 \\
\hline CD69-004 & íntron retido & 3,4560 & 2,4747 \\
\hline RP11-861A13.4-001 & lincRNA & 3,4554 & 2,3494 \\
\hline LINC00926-002 & lincRNA & 3,4264 & 2,3498 \\
\hline RP11-796E2.4-001 & antisenso & 3,4228 & 2,3502 \\
\hline
\end{tabular}


Anexo C - IncRNAs mais expressos nos tumores metástaticos de mama em linfonodo.

\begin{tabular}{|c|c|c|c|}
\hline IncRNA & Tipo & log2Fold change & -log10padj \\
\hline CD69-002 & íntron retido & 3,3125 & 2,1245 \\
\hline LRMP-017 & íntron retido & 3,2681 & 2,4929 \\
\hline LY9-006 & íntron retido & 3,2611 & 2,4273 \\
\hline LINC00861-001 & lincRNA & 3,2347 & 3,8446 \\
\hline P2RX5-003 & íntron retido & 3,2321 & 2,1571 \\
\hline CYTIP-005 & íntron retido & 3,2058 & 2,6335 \\
\hline CTC-457L16.2-001 & antisenso & 3,1525 & 2,8390 \\
\hline IL16-015 & íntron retido & 3,1142 & 2,1125 \\
\hline RP11-76114.4-001 & ncRNA sobreposto a $3^{\prime}$ & 3,1078 & 2,7127 \\
\hline RP3-455J7.4-001 & antisenso & 3,0820 & 2,3502 \\
\hline RP11-77C3.3-002 & antisenso & 2,9986 & 2,1118 \\
\hline RP11-730K11.1-001 & antisenso & 2,9639 & 2,4629 \\
\hline AC006129.2-001 & lincRNA & 2,9609 & 2,5118 \\
\hline AC006129.2-003 & lincRNA & 2,8875 & 2,8592 \\
\hline SNX29P2-001 & lincRNA & 2,8346 & 2,6294 \\
\hline TMEM163-002 & íntron retido & 2,7138 & 2,4920 \\
\hline 7SK.4-001 & lincRNA & 2,6110 & 2,6193 \\
\hline CTD-2306M10.1-001 & lincRNA & 2,5495 & 2,1705 \\
\hline AC007386.4-002 & antisenso & 2,4658 & 2,3663 \\
\hline RP3-323N1.2-001 & antisenso & 2,4415 & 2,2372 \\
\hline TRAF3IP3-004 & íntron retido & 2,3763 & 2,0996 \\
\hline FGD2-002 & íntron retido & 2,3245 & 2,5258 \\
\hline RP11-94L15.2-001 & lincRNA & 2,2698 & 2,1237 \\
\hline RP11-16E12.1-001 & lincRNA & 2,2376 & 2,1791 \\
\hline
\end{tabular}


Anexo D - IncRNAs mais expressos nos tumores metástaticos de mama em cérebro.

\begin{tabular}{cccc}
\hline IncRNA & Tipo & log2Fold change & -log10padj \\
\hline SOX2-OT-008 & senso sobreposto & 5,4457 & 7,2162 \\
MIR137HG-001 & lincRNA & 4,9659 & 3,0307 \\
RP11-731J8.2-001 & senso sobreposto & 4,9327 & 4,3548 \\
KRT23-006 & íntron retido & 4,9128 & 3,0199 \\
\hline RP11-215H22.1-001 & lincRNA & 4,8938 & 2,1800 \\
\hline GRIA2-003 & íntron retido & 4,6603 & 2,3900 \\
\hline RP1-240B8.3-001 & ncRNA sobreposto a 3' & 2,0830 \\
\hline RP11-389G6.3-001 & senso sobreposto & 4,3557 & 2,6009 \\
\hline RP11-286B14.1-001 & lincRNA & 4,3420 & 2,0820 \\
\hline RP11-2L8.1-001 & lincRNA & 4,1462 & 2,2973 \\
\hline RP11-297M9.2-001 & lincRNA & 4,1103 & 2,3104 \\
\hline TMEM132B-001 & íntron retido & 4,0002 & 2,1289 \\
\hline RCAN1-011 & íntron retido & 3,8079 & 2,3656 \\
\hline RP11-379F4.6-001 & lincRNA & 3,3055 & 3,0064 \\
\hline
\end{tabular}


Anexo E - LncRNAs mais expressos nas amostras tumorais, proteínas com as quais interagem e enriquecimento de função molecular e do processo biológico dessas proteínas.

\begin{tabular}{|c|c|c|c|c|}
\hline Amostra & IncRNA & $\begin{array}{l}\text { Proteínas de } \\
\text { interação }\end{array}$ & Função molecular & Processo biológico \\
\hline \multirow{12}{*}{$\begin{array}{c}\text { Mama } \\
\text { (linfonodo } \\
\text { ) }\end{array}$} & \multirow{2}{*}{$\begin{array}{c}\text { RP11- } \\
\text { 400N13.3- } \\
001\end{array}$} & CPSF100 & Ligação de RNA & $\begin{array}{l}\text { Expressão gênica, processamento de extremidade } 3 \text { ' de mRNA, } \\
\text { clivagem de mRNA }\end{array}$ \\
\hline & & MoV10 & $\begin{array}{l}\text { Ligação de ATP, atividade de helicase, ligação de RNA } \\
\text { poli(A) }\end{array}$ & $\begin{array}{l}\text { Via de sinalização do EGFR, via de sinalização Notch, via de } \\
\text { sinalização do FGFR }\end{array}$ \\
\hline & \multirow{4}{*}{$\begin{array}{c}\text { RP5- } \\
\text { 1112F19.2- } \\
001\end{array}$} & elF4AIII & Ligação de ATP, ligação de mRNA, ligação de poli(A) & $\begin{array}{l}\text { Via de sinalização mediada por citocina, splicing de mRNA, regulação } \\
\text { negativa da tradução }\end{array}$ \\
\hline & & Fip1 & Ligação de RNA poli(A) & $\begin{array}{l}\text { Expressão gênica, processamento de extremidade 3' de mRNA, } \\
\text { splicing de mRNA }\end{array}$ \\
\hline & & hnRNPA1 & $\begin{array}{l}\text { Ligação de nucleotídeo, ligação de RNA poli(A), ligação } \\
\text { de DNA dupla-fita }\end{array}$ & $\begin{array}{l}\text { Splicing alternativo de mRNA, exportação e importação nuclear, } \\
\text { regulação da manutenção telomérica via telomerase }\end{array}$ \\
\hline & & LIN28A & Ligação de DNA, ligação de miRNA, ligação de mRNA & $\begin{array}{l}\text { Processamento de pre-miRNA, manutenção de população de células- } \\
\text { tronco somáticas, diferenciação de células-tronco }\end{array}$ \\
\hline & \multirow{6}{*}{$\begin{array}{l}\text { AC099684. } \\
1-001\end{array}$} & DGCR8 & $\begin{array}{l}\text { Ligação de RNA dupla fita, ligação de miRNA primário, } \\
\text { atividade de homodimerização de proteína }\end{array}$ & $\begin{array}{l}\text { Silenciamento gênico por RNA, regulação de proliferação de célula- } \\
\text { tronco, processamento de miRNA primário }\end{array}$ \\
\hline & & elF4AIII & Ligação de ATP, ligação de mRNA, ligação de poli(A) & $\begin{array}{l}\text { Via de sinalização mediada por citocina, splicing de mRNA, regulação } \\
\text { negativa da tradução }\end{array}$ \\
\hline & & hnRNPA1 & $\begin{array}{l}\text { Ligação de nucleotídeo, ligação de RNA poli(A), ligação } \\
\text { de DNA dupla-fita }\end{array}$ & $\begin{array}{l}\text { Splicing alternativo de mRNA, exportação e importação nuclear, } \\
\text { regulação da manutenção telomérica via telomerase }\end{array}$ \\
\hline & & HuR & $\begin{array}{l}\text { Ligação de RNA dupla fita, ligação de RNA, ligação de } \\
\text { nucleotídeo }\end{array}$ & $\begin{array}{l}\text { Estabilização de mRNA, regulação positiva da tradução, regulação da } \\
\text { manutenção de população de células-tronco }\end{array}$ \\
\hline & & NUDT21 & $\begin{array}{l}\text { Ligação de histona deacetilase, atividade de hidrolase, } \\
\text { ligação de mRNA }\end{array}$ & Splicing de mRNA, poliadenilação de mRNA, expressão gênica \\
\hline & & RTCB & $\begin{array}{l}\text { Ligação de ATP, ligação de RNA poli(A), ligação de } \\
\text { vinculina }\end{array}$ & $\begin{array}{l}\text { Desenvolvimento de placenta, processamento de tRNA, } \\
\text { desenvolvimento embrionário }\end{array}$ \\
\hline \multirow{3}{*}{ Linfonodo } & \multirow{3}{*}{$\begin{array}{c}\text { RP11- } \\
\text { 693J15.5- } \\
001\end{array}$} & AGO2 & Atividade endonucleásica, ligação de miRNA e de siRNA & $\begin{array}{l}\text { Via de sinalização do EGFR, via de sinalização Notch, silenciamento } \\
\text { gênico por RNA }\end{array}$ \\
\hline & & hnRNPA1 & $\begin{array}{l}\text { Ligação de nucleotídeo, ligação de RNA poli(A), ligação } \\
\text { de DNA dupla-fita }\end{array}$ & $\begin{array}{l}\text { Splicing alternativo de mRNA, exportação e importação nuclear, } \\
\text { regulação da manutenção telomérica via telomerase }\end{array}$ \\
\hline & & PTB & $\begin{array}{l}\text { Ligação de nucleotídeo, ligação de RNA poli(A), ligação } \\
\text { de pre-mRNA }\end{array}$ & $\begin{array}{l}\text { Splicing alternativo de mRNA, regulação negativa de diferenciação } \\
\text { de célula muscular, processamento de mRNA }\end{array}$ \\
\hline
\end{tabular}

ATP, adenosina tri-fosfato; mRNA, RNA mensageiro; EGFR, receptor de fator de crescimento epidermal; miRNA, micro RNA; tRNA, RNA transportador. 
Anexo E - LncRNAs mais expressos nas amostras tumorais, proteínas com as quais interagem e enriquecimento de função molecular e do processo biológico dessas proteínas.

\begin{tabular}{|c|c|c|c|c|}
\hline Amostra & IncRNA & $\begin{array}{l}\text { Proteínas de } \\
\text { interação }\end{array}$ & Função molecular & Processo biológico \\
\hline \multirow{11}{*}{ Linfonodo } & \multirow{3}{*}{$\begin{array}{c}\text { RP11- } \\
\text { 693J15.5- } \\
001\end{array}$} & AGO2 & $\begin{array}{l}\text { Atividade endonucleásica, ligação de miRNA e } \\
\text { de siRNA }\end{array}$ & $\begin{array}{l}\text { Via de sinalização do EGFR, via de sinalização Notch, silenciamento gênico } \\
\text { por RNA }\end{array}$ \\
\hline & & hnRNPA1 & $\begin{array}{l}\text { Ligação de nucleotídeo, ligação de RNA poli(A), } \\
\text { ligação de DNA dupla-fita }\end{array}$ & $\begin{array}{l}\text { Splicing alternativo de mRNA, exportação e importação nuclear, regulação } \\
\text { da manutenção telomérica via telomerase }\end{array}$ \\
\hline & & PTB & $\begin{array}{l}\text { Ligação de nucleotídeo, ligação de RNA poli(A), } \\
\text { ligação de pre-mRNA }\end{array}$ & $\begin{array}{l}\text { Splicing alternativo de mRNA, regulação negativa de diferenciação de } \\
\text { célula muscular, processamento de mRNA }\end{array}$ \\
\hline & \multirow{2}{*}{$\begin{array}{l}\text { CHRM3- } \\
\text { AS2-001 }\end{array}$} & CPSF100 & Ligação de RNA & $\begin{array}{l}\text { Expressão gênica, processamento de extremidade 3' de mRNA, clivagem de } \\
\text { mRNA }\end{array}$ \\
\hline & & hnRNPF & $\begin{array}{l}\text { Ligação de nucleotídeo, ligação de RNA poli(A), } \\
\text { ligação de RNA fita simples }\end{array}$ & Splicing de mRNA, processamento de RNA, expressão gênica \\
\hline & \multirow{6}{*}{ TCL6-013 } & AGO2 & $\begin{array}{l}\text { Atividade endonucleásica, ligação de miRNA e } \\
\text { de siRNA }\end{array}$ & $\begin{array}{l}\text { Via de sinalização do EGFR, via de sinalização Notch, silenciamento gênico } \\
\text { por RNA }\end{array}$ \\
\hline & & ALKBH5 & $\begin{array}{l}\text { Ligação de íon metal, ligação de RNA poli(A), } \\
\text { atividade de oxidorredutase }\end{array}$ & Diferenciação celular, resposta à hipóxia, processamento de mRNA \\
\hline & & Fip1 & Ligação de RNA poli(A) & $\begin{array}{l}\text { Expressão gênica, processamento de extremidade 3' de mRNA, splicing de } \\
\text { mRNA }\end{array}$ \\
\hline & & FMR1 & $\begin{array}{l}\text { Ligação de mRNA, ligação de RNA poli(A), } \\
\text { ligação de RNA }\end{array}$ & $\begin{array}{l}\text { Desenvolvimento do sistema nervoso central, transporte de mRNA, } \\
\text { regulação negativa da tradução }\end{array}$ \\
\hline & & hnRNPA1 & $\begin{array}{l}\text { Ligação de nucleotídeo, ligação de RNA poli(A), } \\
\text { ligação de DNA dupla-fita }\end{array}$ & $\begin{array}{l}\text { Splicing alternativo de mRNA, exportação e importação nuclear, regulação } \\
\text { da manutenção telomérica via telomerase }\end{array}$ \\
\hline & & hnRNPU & $\begin{array}{l}\text { Ligação de ATP, ligação a enhancer, ligação a } \\
\text { RNA telomerase }\end{array}$ & $\begin{array}{l}\text { Regulação negativa da manutenção do telômero via telomerase, } \\
\text { diferenciação de osteoblasto, splicing de mRNA }\end{array}$ \\
\hline \multirow{4}{*}{$\begin{array}{l}\text { Mama } \\
\text { (cérebro) }\end{array}$} & \multirow{2}{*}{$\begin{array}{l}\text { TBX5-AS1- } \\
001\end{array}$} & AGO2 & $\begin{array}{l}\text { Atividade endonucleásica, ligação de miRNA e } \\
\text { de siRNA }\end{array}$ & $\begin{array}{l}\text { Via de sinalização do EGFR, via de sinalização Notch, silenciamento gênico } \\
\text { por RNA }\end{array}$ \\
\hline & & HuR & $\begin{array}{l}\text { Ligação de RNA dupla fita, ligação de RNA, } \\
\text { ligação de nucleotídeo }\end{array}$ & $\begin{array}{l}\text { Estabilização de mRNA, regulação positiva da tradução, regulação da } \\
\text { manutenção de população de células-tronco }\end{array}$ \\
\hline & \multirow{2}{*}{ LINC00861 } & CPSF100 & Ligação de RNA & $\begin{array}{l}\text { Expressão gênica, processamento de extremidade 3' de mRNA, clivagem de } \\
\text { mRNA }\end{array}$ \\
\hline & & elF4AIII & $\begin{array}{l}\text { Ligação de ATP, ligação de mRNA, ligação de } \\
\text { poli(A) }\end{array}$ & $\begin{array}{l}\text { Via de sinalização mediada por citocina, splicing de mRNA, regulação } \\
\text { negativa da tradução }\end{array}$ \\
\hline
\end{tabular}

ATP, adenosina tri-fosfato; mRNA, RNA mensageiro; EGFR, receptor de fator de crescimento epidermal; miRNA, micro RNA; tRNA, RNA transportador. 
Anexo E - LncRNAs mais expressos nas amostras tumorais, proteínas com as quais interagem e enriquecimento de função molecular e do processo biológico dessas proteínas.

\begin{tabular}{|c|c|c|c|c|}
\hline Amostra & IncRNA & $\begin{array}{l}\text { Proteínas de } \\
\text { interação }\end{array}$ & Função molecular & Processo biológico \\
\hline \multirow{6}{*}{$\begin{array}{l}\text { Mama } \\
\text { (cérebro) }\end{array}$} & LINC00861 & hnRNPA1 & $\begin{array}{l}\text { Ligação de nucleotídeo, ligação de RNA poli(A), } \\
\text { ligação de DNA dupla-fita }\end{array}$ & $\begin{array}{c}\text { Splicing alternativo de mRNA, exportação e importação nuclear, regulação } \\
\text { da manutenção telomérica via telomerase }\end{array}$ \\
\hline & \multirow{5}{*}{ DNM3OS } & CPSF100 & Ligação de RNA & $\begin{array}{l}\text { Expressão gênica, processamento de extremidade 3' de mRNA, clivagem } \\
\text { de mRNA }\end{array}$ \\
\hline & & DGCR8 & $\begin{array}{l}\text { Ligação de RNA dupla fita, ligação de miRNA } \\
\text { primário, atividade de homodimerização de } \\
\text { proteína }\end{array}$ & $\begin{array}{l}\text { Silenciamento gênico por RNA, regulação de proliferação de célula-tronco, } \\
\text { processamento de miRNA primário }\end{array}$ \\
\hline & & FMR1 & $\begin{array}{l}\text { Ligação de mRNA, ligação de RNA poli(A), } \\
\text { ligação de RNA }\end{array}$ & $\begin{array}{l}\text { Desenvolvimento do sistema nervoso central, transporte de mRNA, } \\
\text { regulação negativa da tradução }\end{array}$ \\
\hline & & hnRNPA2/B1 & $\begin{array}{l}\text { Ligação de miRNA, ligação de 3'-UTR de mRNA, } \\
\text { ligação de RNA poli(A) }\end{array}$ & $\begin{array}{l}\text { Transporte de miRNA, processamento de mRNA, regulação negativa do } \\
\text { splicing de RNA }\end{array}$ \\
\hline & & IGF2BP1 & $\begin{array}{l}\text { Atividade reguladora da tradução, ligação de } \\
\text { mRNA, ligação de nucleotídeo }\end{array}$ & $\begin{array}{l}\text { Manutenção de população de células-tronco neuronais, regulação da } \\
\text { estabilidade de mRNA envolvido em resposta ao estresse, transporte de } \\
\text { mRNA }\end{array}$ \\
\hline \multirow{6}{*}{ Cérebro } & \multirow{6}{*}{ SOX2-OT } & ALKBH5 & $\begin{array}{l}\text { Ligação de íon metal, ligação de RNA poli(A), } \\
\text { atividade de oxidorredutase }\end{array}$ & Diferenciação celular, resposta à hipóxia, processamento de mRNA \\
\hline & & CCNT1 & $\begin{array}{l}\text { Ligação à cromatina, ligação a DNA, ligação a } \\
\text { snRNA }\end{array}$ & Divisão celular, ciclo celular, via de sinalização do receptor de TGF- $\beta$ \\
\hline & & CPSF100 & Ligação de RNA & $\begin{array}{l}\text { Expressão gênica, processamento de extremidade 3' de mRNA, clivagem } \\
\text { de mRNA }\end{array}$ \\
\hline & & DGCR8 & $\begin{array}{l}\text { Ligação de RNA dupla fita, ligação de miRNA } \\
\text { primário, atividade de homodimerização de } \\
\text { proteína }\end{array}$ & $\begin{array}{l}\text { Silenciamento gênico por RNA, regulação de proliferação de célula-tronco, } \\
\text { processamento de miRNA primário }\end{array}$ \\
\hline & & elF4AIII & $\begin{array}{l}\text { Ligação de ATP, ligação de mRNA, ligação de } \\
\text { poli(A) }\end{array}$ & $\begin{array}{l}\text { Via de sinalização mediada por citocina, splicing de mRNA, regulação } \\
\text { negativa da tradução }\end{array}$ \\
\hline & & FMR1 & $\begin{array}{l}\text { Ligação de mRNA, ligação de RNA poli(A), } \\
\text { ligação de RNA }\end{array}$ & $\begin{array}{l}\text { Desenvolvimento do sistema nervoso central, transporte de mRNA, } \\
\text { regulação negativa da tradução }\end{array}$ \\
\hline
\end{tabular}

ATP, adenosina tri-fosfato; mRNA, RNA mensageiro; EGFR, receptor de fator de crescimento epidermal; miRNA, micro RNA; tRNA, RNA transportador; TGF- $\beta$, fator de crescimento tumoral beta. 
Anexo E - LncRNAs mais expressos nas amostras tumorais, proteínas com as quais interagem e enriquecimento de função molecular e do processo biológico dessas proteínas.

\begin{tabular}{|c|c|c|c|c|}
\hline Amostra & IncRNA & $\begin{array}{l}\text { Proteínas de } \\
\text { interação }\end{array}$ & Função molecular & Processo biológico \\
\hline \multirow{14}{*}{ Cérebro } & \multirow{9}{*}{ SOX2-OT } & ALKBH5 & $\begin{array}{l}\text { Ligação de íon metal, ligação de RNA poli(A), } \\
\text { atividade de oxidorredutase }\end{array}$ & Diferenciação celular, resposta à hipóxia, processamento de mRNA \\
\hline & & CCNT1 & $\begin{array}{l}\text { Ligação à cromatina, ligação a DNA, ligação a } \\
\text { snRNA }\end{array}$ & Divisão celular, ciclo celular, via de sinalização do receptor de TGF- $\beta$ \\
\hline & & CPSF100 & Ligação de RNA & $\begin{array}{l}\begin{array}{l}\text { Expressão gênica, processamento de extremidade 3' de mRNA, clivagem } \\
\text { de mRNA }\end{array} \\
\end{array}$ \\
\hline & & DGCR8 & $\begin{array}{l}\text { Ligação de RNA dupla fita, ligação de miRNA } \\
\text { primário, atividade de homodimerização de } \\
\text { proteína }\end{array}$ & $\begin{array}{l}\text { Silenciamento gênico por RNA, regulação de proliferação de célula- } \\
\text { tronco, processamento de miRNA primário }\end{array}$ \\
\hline & & elF4AIII & $\begin{array}{l}\text { Ligação de ATP, ligação de mRNA, ligação de } \\
\text { poli(A) }\end{array}$ & $\begin{array}{l}\text { Via de sinalização mediada por citocina, splicing de mRNA, regulação } \\
\text { negativa da tradução }\end{array}$ \\
\hline & & FMR1 & $\begin{array}{l}\text { Ligação de mRNA, ligação de RNA poli(A), ligação } \\
\text { de RNA }\end{array}$ & $\begin{array}{l}\text { Desenvolvimento do sistema nervoso central, transporte de mRNA, } \\
\text { regulação negativa da tradução }\end{array}$ \\
\hline & & hnRNPA1 & $\begin{array}{l}\text { Ligação de nucleotídeo, ligação de RNA poli(A), } \\
\text { ligação de DNA dupla-fita }\end{array}$ & $\begin{array}{l}\text { Splicing alternativo de mRNA, exportação e importação nuclear, } \\
\text { regulação da manutenção telomérica via telomerase }\end{array}$ \\
\hline & & hnRNPH & $\begin{array}{c}\text { Ligação de nucleotídeo, ligação de RNA poli(A), } \\
\text { splicing de RNA }\end{array}$ & Regulação de splicing de RNA, expressão gênica, processamento de RNA \\
\hline & & HuR & $\begin{array}{l}\text { Ligação de RNA dupla fita, ligação de RNA, ligação } \\
\text { de nucleotídeo }\end{array}$ & $\begin{array}{c}\text { Estabilização de mRNA, regulação positiva da tradução, regulação da } \\
\text { manutenção de população de células-tronco }\end{array}$ \\
\hline & $\begin{array}{c}\text { RP11- } \\
286 B 14.1 \\
\end{array}$ & CPSF100 & Ligação de RNA & $\begin{array}{l}\text { Expressão gênica, processamento de extremidade } 3^{\prime} \text { de mRNA, clivagem } \\
\text { de mRNA }\end{array}$ \\
\hline & \multirow{4}{*}{ RP11-2L8.1 } & CCNT1 & $\begin{array}{l}\text { Ligação à cromatina, ligação a DNA, ligação a } \\
\text { snRNA }\end{array}$ & Divisão celular, ciclo celular, via de sinalização do receptor de TGF- $\beta$ \\
\hline & & elF4AIII & $\begin{array}{l}\text { Ligação de ATP, ligação de mRNA, ligação de } \\
\text { poli(A) }\end{array}$ & $\begin{array}{l}\text { Via de sinalização mediada por citocina, splicing de mRNA, regulação } \\
\text { negativa da tradução }\end{array}$ \\
\hline & & Fip1 & Ligação de RNA poli(A) & $\begin{array}{l}\text { Expressão gênica, processamento de extremidade 3' de mRNA, splicing } \\
\text { de mRNA }\end{array}$ \\
\hline & & hnRNPH & $\begin{array}{l}\text { Ligação de nucleotídeo, ligação de RNA poli(A), } \\
\text { splicing de RNA }\end{array}$ & Regulação de splicing de RNA, expressão gênica, processamento de RNA \\
\hline
\end{tabular}

ATP, adenosina tri-fosfato; mRNA, RNA mensageiro; EGFR, receptor de fator de crescimento epidermal; miRNA, micro RNA; tRNA, RNA transportador; TGF- $\beta$, fator de crescimento tumoral beta. 


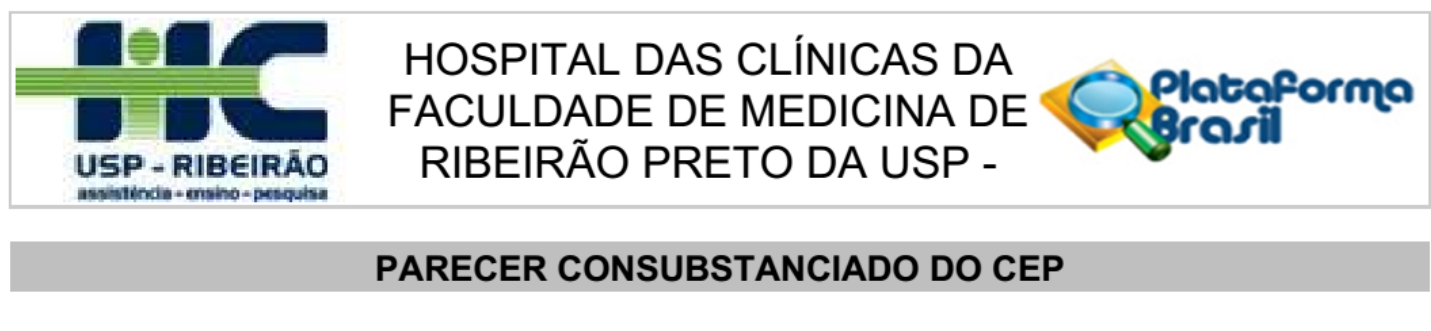

\section{DADOS DO PROJETO DE PESQUISA}

Título da Pesquisa: Análise qualitativa e quantitativa de IncRNA de tumores metastáticos de mama no sistema nervoso central e osso

Pesquisador: Isabela Ichihara de Barros

Área Temática:

Versão: 1

CAAE: 35281214.1 .0000 .5440

Instituição Proponente: Hospital das Clínicas da Faculdade de Medicina de Ribeirão Preto da USP -

Patrocinador Principal: Financiamento Próprio

\section{DADOS DO PARECER}

Número do Parecer: 829.151

Data da Relatoria: $27 / 08 / 2014$

\section{Apresentação do Projeto:}

Trata-se de um estudo que será coordenado pelo Prof. Dr. Wilson Araújo da Silva Jr e pela aluna de mestrado Isabela Ichihara de Barros do programa de pós-graduação em Genética da FMRP-USP. O estudo será realizado por meio da utilização amostras que serão fornecidas pelo Banco de Tumores (aprovação junto ao Comitê de Ética no 7645/99) e pelo Banco de Tumores de Mama (aprovação junto ao Comitê de ética no 2467/2009) do HCFMRP/USP. As amostras de tumores do sistema nervoso central serão obtidas em colaboração com o Prof. Dr. Carlos Gilberto Carlotti Junior e as de tumores ósseo em colaboração com o Prof. Dr. Helton Luiz Aparecido Defino. Serão analisadas 20 amostras de tumor de mama, sendo 5 tumores metastáticos no sistema nervoso central e 5 de tumores metastáticos ósseos. Adicionalmente serão analisados 5 tumores primários, pareados com os respectivos tumores metastáticos

\section{Objetivo da Pesquisa:}

O objetivo Geral do estudo é obter o perfil de expressão de IncRNAs e identificar novos IncRNA associados com tumores metastáticos de sistema nervoso central e osso e os específicos: determinar o perfil de expressão de IncRNAs de tumor de mama metastático no sistema nervoso central e ósseo quanto à: Classificação funcional dos IncRNAs preferencialmente expressos nos tumores metastáticos; e Seleção de IncRNAs potencialmente envolvidos com a metástase.

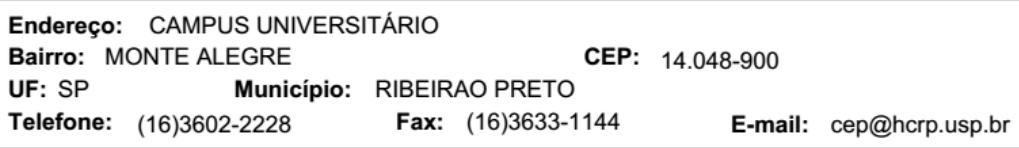


Anexo F - Aprovação do Comitê de Ética em Pesquisa do HCFMRP-USP.

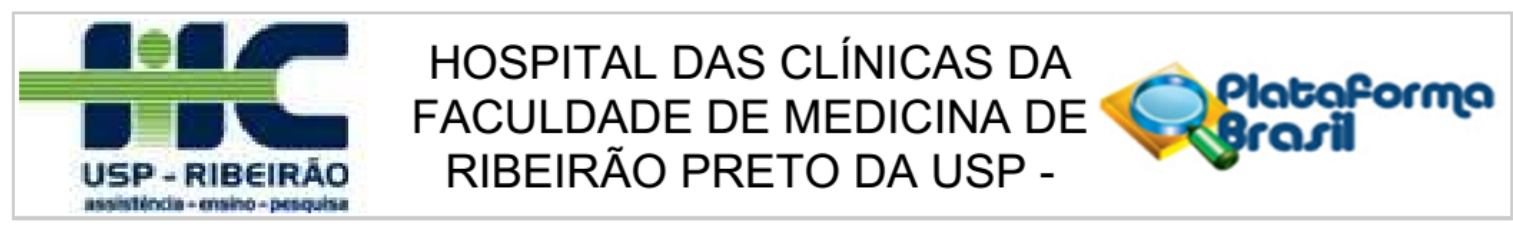

Continuação do Parecer: 829.151

\section{Avaliação dos Riscos e Benefícios:}

Os pesquisadores mencionam que com os resultados obtidos, será possível estabelecer uma assinatura de expressão de IncRNAs, o qual será útil para uma melhor compreensão do

papel efetivo desses RNAs na regulação do mecanismo de metástase, além de possibilitar a identificação biomarcadores de prognóstico e terapêuticos. E descrevem que não há riscos uma vez que não haverá novas coletas para este estudo.

\section{Comentários e Considerações sobre a Pesquisa:}

O projeto está bem descrito contendo todas as etapas com clareza, descrevem critérios de inclusão das amostras para o estudo e a forma de análise de dados. Os pesquisadores solicitam a dispensa do Termo de Consentimento Esclarecido por se tratar de estudo que será realizado com amostras de de tumores de mama já coletadas.

\section{Considerações sobre os Termos de apresentação obrigatória:}

Apresentou folha de rosto devidamente assinada pelo pesquisador e Orçamento que foi aprovado pela Unidade de Pesquisa Clínica (UPC) do HCFMRP-USP; Solicitam dispensa do TCLE visto que os pacientes são graves e que seriam de difícil acesso. Os pesquisadores mencionam que poderão consultar prontuário para confirmação de dados.

\section{Recomendações:}

Considerando que os pesquisadores irão consultar prontuário os pesquisadores resposnáveis devem garantir o sigilo e anonimato das informações pessoais.

Conclusões ou Pendências e Lista de Inadequações:

Diante do exposto e à luz da Resolução CNS 466/2012, o projeto de pesquisa, assim como a solicitação de dispensa de aplicação do Termo de Consentimento Livre e Esclarecido, podem ser enquadrados na categoria APROVADO.

\section{Situação do Parecer:}

Aprovado

\section{Necessita Apreciação da CONEP:}

Não

\section{Considerações Finais a critério do CEP:}

Projeto Aprovado: Tendo em vista a legislação vigente, devem ser encaminhados ao CEP, relatórios parciais anuais referentes ao andamento da pesquisa e relatório final ao término do trabalho. Qualquer modificação do projeto original deve ser apresentada a este CEP em nova versão, de forma objetiva e com justificativas, para nova apreciação.

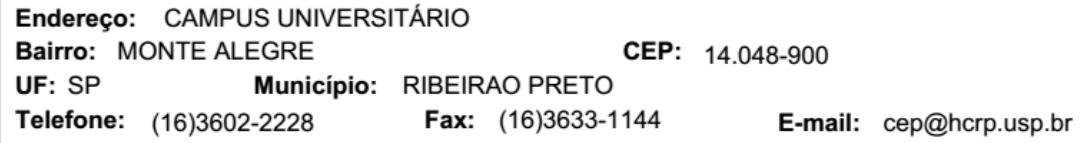

